ROJAS, Luis. "Delitos de omisión entre libertad y solidaridad".

Polít. crim. Vol. 13, № 26 (Diciembre 2018) Art. 2, pp. 682-738.

[http://www.politicacriminal.cl/Vol_13/n_26/Vol13N26A2.pdf]

\title{
Delitos de omisión entre libertad y solidaridad*
}

\section{Unterlassungsdelikte zwischen Freiheit und Solidarität}

\author{
Luis Emilio Rojas A. \\ Doctor en Derecho, \\ Profesor de Derecho Penal, Universidad Alberto Hurtado \\ lurojas@uahurtado.cl
}

\section{Resumen:}

Motivo del presente trabajo es la revisión del criterio que diferencia los delitos impropios de omisión vinculados a la idea de libertad de los delitos propios de omisión fundados en el principio de solidaridad. Actualmente, la categoría de la posición de garante sirve a dicha diferenciación y, al mismo tiempo, constituye el elemento básico de equivalencia de los delitos de omisión con los delitos de acción correspondientes. Dicha categoría dogmática, empero, surgió en el contexto histórico de una discusión entre la jurisprudencia alemana de principios del siglo XX y la doctrina de la época, donde el concepto de causalidad y el rol que ésta cumplía en el ámbito de la omisión eran fuertemente controvertidos. La categoría de la posición de garante, acuñada y desarrollada por la dogmática, sirve para compensar normativa y valorativamente el déficit de causalidad que la propia dogmática ve en la omisión. Con el desarrollo de la dogmática moderna, en particular, de su teoría de la imputación objetiva, pero también la revisión del concepto de causalidad, la categoría de la posición de garante se ha vuelto prescindible.

Palabras claves: omisión impropia - causalidad - posición de garante - deber jurídico

\section{Zusammenfassung:}

Anlass der vorliegenden Abhandlung ist die Diskussion über das Unterscheidungskriterium der mit der Idee der Freiheit zusammenhängenden unechten Unterlassungsdelikte von den auf dem Solidaritätsprinzip beruhenden echten Unterlassungsdelikten. Dieser Unterscheidung dient heutzutage die Kategorie der Garantenstellung und stellt sie zugleich das Grundmerkmal zur Gleichstellung der Unterlassungsdelikte mit den entsprechenden Handlungsdelikten dar. Diese dogmatische Kategorie ist jedoch in dem historischen Kontext einer Auseinandersetzung der vom Anfang des 20. Jahrhunderts deutschen Rechtsprechung mit der damaligen Lehre entstanden, in dem der Begriff der Kausalität und deren Stellung im Bereich der Unterlassung sehr umstritten waren. Die von der Lehre geprägte

\footnotetext{
* Trabajo elaborado en el marco del proyecto Fondecyt N. 1150178 sobre "Líneas básicas de una dogmática de los delitos propios de omisión: una aproximación a los deberes de solidaridad y al significado de su infracción", cuyo investigador responsable es el autor; coinvestigadora en el proyecto es la Dra. María Soledad Krause; agradecimientos al ayudante de investigación Claudio Quintana; se extienden los agradecimientos también a los colegas Iván Navas, Ivó Coca, Lautaro Contreras y Javier Wilenmann por las críticas y observaciones formuladas a diversas versiones previas del presente trabajo.
} 
ROJAS, Luis. "Delitos de omisión entre libertad y solidaridad".

Kategorie der Garantenstellung kompensiert sozusagen normativ und bewertend gerade das Defizit der Kausalität, das die Lehre selbst bei dem Unterlassen annimmt. Infolge der modernen Dogmatik, vor allem der Lehre von der objektiven Zurechnung, aber auch der jüngeren Diskussion über den Begriff der Kausalität, ist die Kategorie der Garantenstellung entbehrlich geworden.

Stichworte: Unechtes Unterlassungsdelikt - Kausalität - Garantenstellung - Rechtspflicht

\section{Planteamiento del problema}

En la dogmática que se ocupa de la parte general del Derecho penal, se tiende a relacionar el delito de acción con la idea de libertad, en el sentido de que ésta se ve amagada principalmente por esa forma de realización delictiva. Menos obvio, en cambio, es el modo en que el delito de omisión entronca con esa idea fundamental. En una concepción liberal del Derecho penal, esto es, que se funda en el principio de libertad, el lugar de esta figura delictiva no es evidente. Una indagación en el origen histórico de esta disímil relación con tal principio, empero, tendría que remontarse a la época fundacional del Derecho penal moderno. Situada en este contexto originario, a su vez, se pondría de manifiesto que esa relación es tributaria de una determinada filosofía del Derecho.

En efecto, esta relación disímil del delito de acción y de omisión con la idea de libertad puede reconducirse a un concepto negativo de Derecho, según el cual éste es el conjunto de presupuestos en cuyo marco el arbitrio de una persona puede coexistir con el arbitrio de otra, esto último, de acuerdo con una ley general de la libertad. ${ }^{1}$ En este sentido, si ya el Derecho como tal se concibe de esa forma, entonces el Derecho penal no tiene más alternativa que reducirse también a la protección de la libertad de otro.

Pues bien, el planteamiento de Feuerbach es tributario de ese concepto de Derecho ${ }^{2}$. Sobre esta base, el fundador de la ciencia del Derecho penal concibe el delito como una acción que se encuentra amenazada con una pena por la ley y que lesiona el derecho de otro -la libertad ${ }^{3}$. Dado que la vinculación originaria exige del ciudadano omitir la lesión de los derechos de otro, entonces es coherente con esa premisa proteger la libertad sólo frente a las acciones del ciudadano. Por consiguiente, un delito de omisión, en principio, no es si-

\footnotetext{
${ }^{1}$ KANT, Immanuel, Die Metaphysik der Sitten (Einleitung in die Rechtslehre), $1^{\text {a }}$ ed. 1797 A 33; $2^{\mathrm{a}}$ ed. 1798 B 33, 34, Frankfurt a.M.: Suhrkamp, 1978, p. 337; cfr. HRUSCHKA, Joachim, Kant und der Rechtsstaat, Freiburg/München: Karl Alber, 2015, pp. 17 y ss.; PAWLIK, Das Unrecht des Bürgers, Tübingen: Mohr Siebeck, 2012, pp. 141 y ss.: en Kant, el Derecho aparece como "condición de posibilidad de la existencia de seres libres" que, en tanto se relacionan entre sí como personas, sus acciones externas sufren iguales restricciones que las de su propio ámbito jurídico de movimiento (p. 144); lo distintivo de esta concepción liberal de Derecho radica en que la pretensión del otro constituye un límite inmanente de mi esfera jurídica, pues la libertad no es sólo mía, sino que desde su origen igualmente la del otro (p. 144 y s.).

${ }^{2}$ FEUERBACH, Lehrbuch des gemeinen in Deutschland gültigen peinlichen Rechts, 14. ed, Giessen: Scientia Verlag (Aalen), 1847, § 8; el punto de partida es común con KANT, las diferencias quedan luego en evidencia a propósito del fin de la imposición de la pena, cfr. HRUSCHKA, Kant und der Rechtsstaat, cit. nota ${ }^{\circ}{ }^{\circ}$, p. $108 \mathrm{y} \mathrm{s}$.

${ }^{3}$ FEUERBACH, Lehrbuch, cit. nota $n^{0} 2, \S 21$; luego precisa FEUERBACH, Lehrbuch, cit. nota $n^{0} 2$, § 23, que los derechos pueden ser tanto del Estado ("como personal moral": jurídica), cuya lesión da lugar a un crimen público, como del súbdito (ciudadano), en cuyo caso la lesión configura un delito privado.
} 
Polít. crim. Vol. 13, No 26 (Diciembre 2018) Art. 2, pp. 682-783.

[http://www.politicacriminal.cl/Vol_13/n_26/Vol13N26A2.pdf]

quiera pensable. La libertad no puede verse afectada mediante omisión. Si se admite su castigo, lo es de un modo excepcional, es decir, siempre que concurra un fundamento jurídico especial -ley o contrato-, i.e., que obligue a una actividad respecto de la cual una persona tiene correlativamente un derecho a su realización ${ }^{4}$.

La aceptación de esa premisa fundamental trae como consecuencia que el delito de omisión tiende a ubicarse en el borde externo del Derecho penal e incluso llega a traspasar los límites del Derecho, para invadir el campo de la moral. No sería una figura nuclear del Derecho penal, sino que más bien marginal y, en todo caso, necesitada de justificación especial ${ }^{5}$. En esa medida, el delito de omisión se concibe de modo esencialmente distinto al delito de acción. Este punto de partida explica que la doctrina discuta con la jurisprudencia, en el caso ejemplar de la tradición jurídica alemana, de una forma muy diferenciada ya durante la segunda mitad del siglo XIX, sobre los requisitos que deben concurrir para el castigo de una omisión como un delito de acción -comisión por omisión-, vale decir, para la aplicación de la misma pena ${ }^{6}$.

4 FEUERBACH, Lehrbuch, cit. nota $\mathrm{n}^{\mathrm{o}} 2$, $\S 24$; en este sentido, SPANGENBERG, „Über Unterlassungsverbrechen und deren Strafbarkeit“, Neues Archiv für Criminalrecht, t. IV sección 4ª (1821), pp. 528 y ss., parte del principio básico, según el cual „la obligación del ciudadano estatal o súbdito se dirige solamente a omisiones"; la configuración excepcional de un delito de omisión presupone la existencia de un deber surgida de un fundamento jurídico especial, el incumplimiento de ese deber mediante la omisión de la acción ordenada y la realización de un daño en el sujeto que se encuentra jurídicamente facultado para exigir su realización (pp. 529 y ss.); en cuanto al primer presupuesto, identifica tres fuentes: la ley positiva, las relaciones jurídicas especiales y el contrato; en ausencia todavía de una codificación nacional, la ley positiva se extrae tanto del Derecho común (romano) como de las "leyes territoriales" (legislación particular de cada Reino), donde Spangenberg menciona, entre otras, disposiciones como aquella que obliga a prestar ayuda a otro hombre que se encuentra en peligro vital o la del $§ 191,192$ del Código penal austríaco que considera un favorecedor del delincuente a aquel que omite la evitación del crimen (p. 535); en el ámbito de las relaciones jurídicas especiales, y luego de advertir el riesgo de confundir deberes morales con obligaciones jurídicas, señala que la ley establece un vínculo interno especial entre ciertas personas, en virtud del cual éstas se deben protección y ayuda, como por ejemplo, entre ascendientes y descendientes o entre cónyuges (p. 538 y s.); fuera de estas relaciones jurídicas, la omisión de ayuda o de impedir un crimen, constituye sólo una "infamia moral", siempre que una ley positiva tampoco lo ordene (p. 541 y s.); finalmente, el contrato puede suplir la ausencia de obligación jurídica en esos casos, por ejemplo, el contrato de servicio público, el del médico que se obliga a enfrentar una epidemia infecciosa o del bombero a combatir los incendios, siempre que se haya convenido de modo explícito y determinado y que se encuentre dirigido a esas acciones específicas: "no pueden suponerse contratos implícitos, porque tales suposiciones son arbitrarias y muy distintas según la individualidad del que supone, y no son aptas para conducir a efectos ciertos (...)" (p. 543 y s.).

${ }^{5}$ Un versión contemporánea de esta visión se percibe en SEELMANN, Kurt, “Opferinteressen und Handlungsverantwortung in der Garantenpflichtdogmatik“, Goltdammer's Archiv für Strafrecht (GA) (1989), pp. 247 y ss.: la responsabilidad por omisión plantea, en general, el dilema que los deberes de acción, a diferencia de los deberes de omisión, no pueden determinarse de un modo general ni preciso; la imputación de un delito de omisión es doblemente especial, primero, porque es explícitamente normativa, "ya que falta la evidencia manifiesta del nexo de causalidad para la imputación", y, segundo, porque el reproche se funda, no en la circunstancia de que el sujeto haya colocado una causa, sino en que él debió, conforme a un criterio orientado a estándares sociales, interrumpir un curso causal ya en curso y, por ende, para fundar esta imputación, las normas no derivan solamente del Derecho.

${ }^{6}$ Una síntesis de la discusión doctrinaria y jurisprudencial en MERKEL, Paul, Begehung durch Unterlassung, Nürnberg: W. Tümmels Buch- und Kunstdruckerei, 1895, pp. 5 y ss., 31 y ss., 40 y ss., 46 y ss. 
ROJAS, Luis. "Delitos de omisión entre libertad y solidaridad".

Al menos en la ciencia del Derecho penal, dicha ubicación marginal del delito de omisión se mantiene durante gran parte del siglo $\mathrm{XX}^{7}$. En algún momento, que puede situarse en la época de la postguerra -segunda-, cuando la dogmática jurídica empieza a recurrir al concepto de solidaridad ${ }^{8}$, el delito de omisión llega incluso a relacionarse con esta idea divergente $^{9}$. En particular, la omisión de socorro no parece tener otro fundamento que el principio de solidaridad ${ }^{10}$. Pero no solamente esta clase de omisión. Ya Gallas se manifiesta contrario en aceptar una "posición de garantía" fundada solamente en la relación matrimonial o familiar, con excepción de las relaciones entre padres e hijos, de modo tal que la omi-

\footnotetext{
${ }^{7}$ Por influencia sobre todo de RADBRUCH, Gustav, Der Handlungsbegriff in seiner Bedeutung für das Strafrechtssystem, Darmstadt: Wissenschaftliche Buchgesellschaft, 1967, p. 132: "así como nada puede surgir de la nada, tampoco puede la nada convertirse en algo. La causalidad une transformación con transformación, la no realización de una transformación no puede ser efecto ni causa"; dado que RADBRUCH, Gustav, Der Handlungsbegriff, cit. nota $\mathrm{n}^{\circ} 7$, p. 75 , define hecho como un "movimiento corporal unido causalmente con el resultado", entonces la omisión, a diferencia que la acción, no pertenece al concepto de hecho, pues en aquélla no hay movimiento corporal, ni resultado, ni causalidad, tampoco voluntad (p. 137 y s.); más bien la omisión reside en la "negación de una acción determinada", de modo que tal como es cierto que posición y negación, a y non-a, no pueden subsumirse bajo un concepto superior, también deben "acción y omisión encontrarse desvinculados una junto a la otra" (p. 141 y s.).

${ }^{8}$ Sobre el origen jurídico del concepto de solidaridad, en tanto proviene de las obligaciones solidarias del Derecho romano, pero que recién a fines del siglo XIX comienza a invocarse en el ámbito de la política y de la moral, cfr. BAYERTZ, Kurt, "Begriff und Problem der Solidarität", en: BAYERTZ, Kurt, (ed.): Solidarität, Begriff und Problem, Frankfurt a.M.: Suhrkamp, 1998, pp. 11 y ss; y STEINVORTH, Ulrich, "Kann Solidarität erzwingbar sein?”, BAYERTZ, Kurt, (ed.): Solidarität, cita nota n ${ }^{\circ}$ 8, pp. 55 y ss.

${ }^{9}$ En la dogmática jurídico-penal, por ejemplo, SAMSON, Eric, "Begehung und Unterlassung”, en: Stratenwerth/Kaufmann/Geilen/Hirsch/Schreiber/Jakobs/Loos (eds.) Festschrift für Hans Welzel zum 70. Geburtstag, Berlin/New York: De Gruyter, 1971, p. 595: "Las prohibiciones derivan así del pensamiento individualista, los mandatos determinan el alcance del deber a la solidaridad recíproca"; según SEELMANN, "GA 1989", cit. nota $\mathrm{n}^{\mathrm{o}} 5$, p. 252 y s., los deberes de auxilio plantean problemas de legitimación, en tanto no derivan de una acción responsable así como tampoco constituyen presupuestos de la existencia de un sistema de deberes basado en el principio de la responsabilidad por acción; la solución de compromiso del tipo general de omisión de socorro es sostenible, en la medida en que la pena amenazada se mantiene muy por debajo de la correspondiente a la causación de las consecuencias respectivas, pero las dudas persisten frente a los deberes de garante que se fundan en el "principio de solidaridad o de intereses".

${ }^{10}$ Cfr. GALLAS, Wilhelm, „Zur Revision des § 330c StGB“, Juristenzeitung, n 13/14 (1952), p. 396 (la dependencia recíproca y solidaridad necesaria entre todos los miembros jurídicos así como el pensamiento de la responsabilidad social entre comunidad e individuo); WELZEL, Hans, "Zur Dogmatik der echten Unterlassungsdelikte“, Neue Juristiche Wochenzeitung, no 9 (1953), p. 328 (responsabilidad social del ciudadano en una democracia social); SEELMANN, Kurt, "Solidaritätspflichten im Strafrecht?", en: Jung/MüllerDietz/Neumann (eds.), Recht und Moral, Baden-Baden: Nomos, 1991, pp. 298 y ss. (problemas de la juridificación de deberes morales); KARGL, Walter, "Unterlassene Hilfeleistung (§ 323c StGB), Zum Verhältnis von Recht und Moral", Goltdammer's Archiv für Strafrecht (1994), p. 251 y s. (deber ético fundido en forma jurídica y juridificación de deberes morales de conducta); ALCÁCER, Rafael, „Autonomía, solidaridad y deber de socorro (un apunte histórico)", $A D P C P$ vol. LIII (2000), pp. 365 y ss. (p. 366: solidaridad como antónimo de la idea de autonomía); VARONA, Daniel, Derecho penal y solidaridad, Madrid: Dykinson, 2005, pp. 103 y ss., 127 y ss., sobre los problemas de legitimación del "mandato penal de socorro" en el contexto anglosajón; de otra opinión, KÜHL, Kristian, Freiheitliche Rechtsphilosophie, Baden-Baden: Nomos, 2008, pp. 368 y ss., 373 y s., quien funda el deber de solidaridad en el principio de generalización y, concurriendo presupuestos adicionales, reconduce el deber general de socorro y el de tolerancia en la hipótesis de estado de necesidad agresivo a la concepción kantiana de Derecho; cfr. EL MISMO, "Zur Anwendung des Solidaritätsbegriffs auf die unterlassene Hilfeleistungspflicht nach § 323c StGB", en: von Hirsch/Neumann/Seelmann (eds.) Solidarität im Strafrecht, Baden-Baden: Nomos, 2013, pp. 97 y ss. (p. 101: solidaridad referida o funcional a la libertad).
} 
sión en esos casos se sustrae del régimen de la comisión por omisión y queda sometida nada más que al tipo general de la omisión de socorro ${ }^{11}$.

A partir de ese momento, una diferencia esencial que hasta entonces se observaba en las formas de manifestación del delito - de acción y de omisión-, se replantea en los términos de una cuestión de fundamento normativo. Lo determinante ya no es la forma externa de la conducta -acción versus omisión-, sino que la clase de deberes que fundamentan la responsabilidad. En esta línea de pensamiento, se ponen en contraste los deberes negativos, que obligan a no sobrepasar el ámbito propio de organización en desmedro de la esfera de libertad de otro, con los deberes positivos, que exigen realizar una prestación en beneficio de otro con un grado de sacrificio de la libertad propia más bien característico de los deberes morales ${ }^{12}$. En este orden de ideas, la legitimación de los deberes negativos sería pacífica, en tanto éstos constituyen expresión del sinalagma entre libertad y responsabilidad por las consecuencias ${ }^{13}$. En cambio, el status de los deberes positivos resulta fuertemente controvertido en la doctrina más reciente ${ }^{14}$. El carácter positivo de esta clase de deberes, acuñado en los términos de prestar un beneficio en favor de otro, sería común tanto a los deberes institucionales como al deber general de solidaridad. Esta característica común implicaría tachar a esta clase de deberes con un tinte moralizante, de tal modo que el mero incumplimiento de un deber positivo especial -institucional- no podría calificarse de equivalente a la infracción de los deberes negativos y, por ende, quedaría relegado al ámbito propio de la infracción al deber general de solidaridad.

Como se puede ver, la crítica reseñada a los deberes positivos replantea en términos explícitamente normativos la discusión tradicional que antes se planteaba en torno a la equivalencia entre las formas de realización del delito de acción y de omisión -impropia. Se trata de formas distintas de abordar el mismo problema ${ }^{15}$. La perspectiva tradicional se pregunta por los elementos comunes al delito de acción y al delito de omisión, en términos

${ }^{11}$ GALLAS, Wilhelm, Studien zum Unterlassungsdelikt, Heidelberg: C.F. Müller, 1989, pp. 92 y ss.

${ }^{12}$ De hecho, KANT, Die Metaphysik der Sitten, cit. nota n ${ }^{\circ} 1$, p. 551 y s. (1 $1^{\text {a }}$ ed. 1797 A 66, 67), introduce esta clasificación (objetiva) a propósito de los debes contra sí mismo, en el acápite sobre doctrina elemental de la ética; HEGEL, G. W. F., Doctrina del derecho, los deberes y la religión para el curso elemental, Buenos Aires: Biblos, 2010, § 35 p. 90 y s., en el capítulo sobre doctrina de los deberes o la moral, explica que los preceptos de la moral, en contraste con el mandato jurídico, ordenan proporcionar algo positivo al otro.

13 Por todos, JAKOBS, Günther, Die strafrechtliche Zurechnung von Tun und Unterlassen, Opladen: Westdeutscher Verlag, 1996, pp. 19 y ss.

${ }^{14}$ Por todos, SÁNCHEZ-VERA, Javier, Pflichtdelikt und Beteiligung, Berlin: Duncker \& Humblot 1999, pp. 76 y ss. (instituciones positivas), pp. 103 y ss. (respuesta ante la crítica de la moralización ilícita del Derecho); crítica de ROBLES, Ricardo, „Deberes negativos y positivos en Derecho penal”, en InDret n 4 (2013), pp. 6 y s., 9 y ss. (la mera infracción de deberes positivos, que no se reconduce a criterios de imputación objetiva, es estructuralmente disímil a la infracción de deberes negativos); SILVA SÁNCHEZ, Jesús María, "Zur Dreiteilung der Unterlassungsdelikte", en: Schünemann/Achenbach/Bottke/Haffke/Rudolphi (eds.) Festschrift für Claus Roxin zum 70. Geburtstag, Berlin/New York: De Gruyter, 2001, p. 648 y s.

${ }^{15}$ PAWLIK, Michael, „'Das dunkelste Kapitel in der Dogmatik des Allgemeinen Teils‘. Bemerkungen zur Lehre von den Garantenpflichten“, en: Heinrich/ Jäger/ Achenbach/ Amelung/ Bottke/ Schünemann/ Haffke/ Wolter (eds.) Festschrift für Claus Roxin zum 80. Geburtstag, Berlin/New York: De Gruyter, 2011, pp. 935 y ss., critica la primera perspectiva instalada por Feuerbach como un efecto reflejo, concerniente a la forma de comisión, de una teoría de los deberes. 
ROJAS, Luis. "Delitos de omisión entre libertad y solidaridad".

tales de que si concurren justifican la aplicación de la misma pena. Por su parte, la perspectiva normativa hace ver que detrás de esta discusión se esconde una cuestión que atañe a una clase distinta de deberes, de tal manera que la aplicación de la misma pena se vuelve dependiente de la infracción a deberes equivalentes, constatación que resultaría dudosa en el caso de los deberes positivos.

\section{Contextualización del problema en la tradición jurídica nacional e hipótesis de tra- bajo}

En la tradición jurídica nacional, cabe destacar el señero trabajo de Bustos, Flisfisch y Politoff, publicado en 1966, acerca de las diferencias entre la omisión de socorro y el homicidio por omisión ${ }^{16}$. Según estos autores, ambas figuras son verdaderos delitos de omisión y tienen en común que se diferencian de los delitos de acción por la ausencia de causalidad. Entre ambas clases de omisión, no observan una diferencia en el plano subjetivo. Incluso sostienen que, en la figura de omisión de socorro, también se busca la protección de los bienes jurídicos vida e integridad corporal.

Mas una diferencia radica en que, en el caso de la omisión impropia, no se trata meramente de "solidaridad humana", sino que el sujeto tiene una "posición de custodio" del bien tutelado, llamada "posición de garante" y de la cual surge un "deber específico" de actuar". En cambio, en la figura de omisión de socorro se trata de una "norma imperativa general" dirigida a todos los súbditos, de modo tal que entre autor y víctima solamente "median las relaciones generales de una sociedad"18. Así, comparan el caso de la madre que no amamanta a su hijo, "pereciendo éste de inanición", con "el panadero que no proporciona un pan al mendigo que ha venido a morir de hambre a la puerta de la panadería", observando que en este segundo caso la "ilicitud es diferente: resulta de los deberes que la solidaridad impone en general a los súbditos, no de la infracción de un mandato específico"19.

\footnotetext{
${ }^{16}$ BUSTOS, Juan, FLISFISCH, Ángel, POLITOFF, Sergio, "Omisión de socorro y homicidio por omisión", Revista de Ciencias Penales, 1966, $3^{\mathrm{a}}$ época, $\mathrm{n}^{\mathrm{o}} 3$, t. XXV, pp. 163 y ss.

${ }^{17}$ BUSTOS/FLISFISCH/POLITOFF, "RCP 1966", cit. nota $n^{\circ}$ 16, pp. 168 y ss.; pero esa diferencia tampoco sería "absoluta": "en verdad, la única diferencia absoluta es que los unos (los propios) están legislados y los otros no" (p. 172); si, de acuerdo a este planteamiento, la única diferencia "absoluta" radica en la tipificación de los delitos (propios) de omisión, entonces significa que la "posición de garantía" sólo traza una diferencia "relativa" ("cuantitativa"), en este sentido, ya KAUFMANN, Armin, Dogmatik der Unterlassungsdelikte, Göttingen: Otto Schwartz \& Co., 1959, pp. 275 y s., 303 y ss.

${ }^{18}$ BUSTOS/FLISFISCH/POLITOFF, "RCP 1966", cit. nota no 16, p. 180.

19 BUSTOS/FLISFISCH/POLITOFF, "RCP 1966", cit. nota $\mathrm{n}^{\circ} 16, \mathrm{p}$. 181; después, precisan más el fundamento de la figura de omisión de socorro con la idea de delegación, en el sentido de que el Estado tiene una función asistencial que delega, en casos extremos, en "el primero que llega": "Así, cualquier súbdito del ordenamiento jurídico pasaría a asumir la representación del estado frente al desvalido que requiere de auxilio urgente (...) El fundamento de esta delegación estaría vinculado a la transformación del estado moderno, de un ente que cumple funciones policíacas, de acuerdo con una mentalidad liberal, a uno en que los ciudadanos tienen derechos y responsabilidades sociales" (p. 183; destacado agregado); PAWLIK, Michael, "Unterlassene Hilfeleistung: Zuständigkeitsbegründung und systematische Struktur", Goltdammer's Archiv für Strafrecht (1995), p. 364 y s., recurre posteriormente a estas mismas ideas de delegación y representación para la legitimación de la norma del $\S 323$ c StGB sobre omisión de socorro; recientemente, EL MISMO, "Solidaridad como categoría de legitimación jurídico-penal: El ejemplo del estado de necesidad agresivo justificante", Revista de Estudios de la Justicia, no 26 (2017), pp. 238 y ss.
} 
Polít. crim. Vol. 13, No 26 (Diciembre 2018) Art. 2, pp. 682-783.

[http://www.politicacriminal.cl/Vol_13/n_26/Vol13N26A2.pdf]

El planteamiento reseñado de la doctrina nacional parte de una diferencia estructural entre el delito de acción y los delitos de omisión, derivada de la ausencia de causalidad en estos últimos. Luego busca un criterio normativo que pueda de alguna manera compensar esa diferencia. En este sentido, se aborda el problema tanto en el plano de las formas de realización de la conducta como desde la perspectiva normativa de la clase de deberes involucrada. Así, se identifica a la "posición de garante" como el elemento normativo que diferencia la omisión impropia del tipo de omisión de socorro, fundado este último en la idea de "solidaridad humana". Es decir, el elemento de la "posición de garantía" integra la figura del homicidio por omisión y, por lo tanto, justifica la equivalencia entre su realización activa y su comisión por omisión. Lo interesante de esta propuesta es que identifica la "posición de garantía" como el mismo elemento normativo que diferencia la omisión impropia del tipo de omisión de socorro y, al mismo tiempo, vuelve equivalente dicha omisión impropia con el respectivo delito de acción, en este caso, de homicidio.

Esta discusión sobre los criterios de equivalencia entre delito de acción y de omisión y, al mismo tiempo, de diferenciación entre la omisión impropia y los delitos propios de omisión, no tiene un alcance puramente teórico. Es muy relevante en la praxis, pues la pena que corresponde aplicar en el caso de una omisión equivalente a un delito de acción es regularmente mucho mayor que la contemplada para un delito propio de omisión.

Dicha relevancia puede ilustrarse mediante un par de casos extraído de la jurisprudencia de nuestros Tribunales superiores de Justicia. Ambos casos pertenecen a una época en la cual recién se estaban acuñando los criterios de identificación y castigo del delito de omisión. Así, por ejemplo, en un caso de principios del año 1913 sucedido en la laguna Lanalhue, cuando José C. conducía un barco a vapor desde Contulmo a Peleco, que llevaba amarrada una lancha con pasajeros y una carga compuesta de (14) caballos, una yunta de bueyes, una carreta, cajones de mercadería y barricas de vino. La lancha empezó a hundirse y, no obstante la reiterada petición de los pasajeros en orden a cortar las amarras, el conductor del vapor se opuso a dicha maniobra porque le parecía "un sacrificio inútil" perder la lancha. Murieron ahogados cuatro pasajeros, los cuales habrían podido ser rescatados de haber tomado José C. oportunamente la decisión de cortar las amarras y perder la carga que llevaba la lancha ${ }^{20}$. El hecho fue calificado como un "cuasidelito" de homicidio.

El otro caso ocurre en Lebu, en la mañana del 29 de septiembre de 1935, cuando la embarazada Berta H., luego de sentir un malestar abdominal, pare en la letrina de la casa de sus tíos. El bebé murió ahogado en los excrementos mientras ella permanecía sentada en el cajón, sin haberse dado cuenta cabalmente de que estaba pariendo ${ }^{21}$. La Iltma. Corte de Apelaciones de Concepción califica el hecho como delito de infanticidio, "cometido por omisión de actos que debió ejecutar la inculpada, a fin de evitar la muerte segura de su hijo que necesariamente debe ocurrir al dejarlo abandonado, como lo hizo, en el pozo lleno de excrementos" 22 .

\footnotetext{
${ }^{20}$ SCA Concepción, 10.12.1917, Gaceta de los Tribunales (GT), 1917, $2^{\circ}$ sem., Santiago 1926, pp. 1073 y ss.

${ }^{21}$ SCA Concepción, 20.11.1939, GT 1939, $2^{\circ}$ sem., Santiago 1940, pp. 779 y ss.

${ }^{22}$ SCA Concepción, 20.11.1939, GT 1939, $2^{\circ}$ sem., p. 783 y s. (considerando $8^{\circ}$ ).
} 
ROJAS, Luis. "Delitos de omisión entre libertad y solidaridad”.

Como se puede ver, ambos casos se ubican en el límite entre delito de acción y de omisión. De hecho, el "caso de la lancha" fue calificado sin más como "cuasidelito" de homicidio, a pesar de que el acento del reproche se pone en el comportamiento de no cortar las amarras que la unían al "vapor" y en su efecto de no socorrer a los pasajeros que iban en la lancha. Asimismo, la circunstancia de que la lancha se encontraba con una carga excesiva e incluso en mal estado, sitúa este caso en el ámbito de problemas que se discute bajo el acápite de la injerencia. El otro caso también se ubica en el límite entre delito de acción y de omisión, pero con la diferencia de que la Corte de Apelaciones explicita el fundamento del reproche en la omisión de sacar al bebé recién nacido del pozo y, luego, en la conducta de abandonarlo. La pregunta que surge, en este caso, concierne al alcance del deber que tenía la madre de sacar a su hijo del pozo y al significado de su infracción. Es decir, el segundo caso se ubica más bien en el ámbito de la discusión sobre la existencia y alcance de los deberes positivos en el ámbito del delito de omisión.

El problema descrito acerca de los criterios de equivalencia entre delito de acción y de omisión y de diferenciación, al interior de este último, entre omisión propia e impropia, se agudiza en el contexto de la legislación nacional. Pues, fuera de la referencia explícita a la omisión al lado de la acción ya en el art. $1^{\circ}$ del Código penal, este cuerpo legal no cuenta hasta ahora con una regla en su parte general que reconozca la figura de la omisión impropia y establezca sus requisitos básicos de aplicación. El mentado juicio de equivalencia depende en nuestro contexto de criterios desarrollados por la doctrina y jurisprudencia, estado de incerteza que manifiestamente genera serios problemas de compatibilidad con el principio de legalidad en esta dimensión ${ }^{23}$.

Pues bien, a continuación se ofrece una revisión histórico-dogmática de los criterios de equivalencia entre delito de acción y de omisión hasta llegar a la época de acuñación del concepto de posición de garante. La hipótesis general del trabajo consiste en que la formulación del principio de garantía se explica como una reacción del pensamiento orientado materialmente frente a la teoría formal del deber jurídico sostenida por la jurisprudencia del Tribunal Supremo del Reich (Reichsgericht) en Alemania. En la época durante la cual se acuña el concepto de posición de garante en el sentido actual de la expresión, no se había desarrollado aún una teoría de la imputación objetiva con la pretensión general de explicar el fundamento material de la responsabilidad penal tanto por una acción como por una omisión.

La tesis que se sostiene radica en que el desarrollo posterior de dicha teoría ha vuelto prescindible la categoría misma de la posición de garante -vid. infra 5. Si se abandona esta categoría, queda en pie el requisito de la existencia formal de un deber jurídico especial de evitación, en el sentido de la teoría formal del deber jurídico. En esta dirección, se postula

\footnotetext{
${ }^{23}$ Sobre este problema, que denomina de "compatibilidad formal", recientemente WILENMANN, Javier, "Sobre la estructura argumentativa de los delitos de omisión impropia", en: Cárdenas/Ferdman (coords.) El Derecho Penal como Teoría y como Práctica. Libro Homenaje a Alfredo Etcheberry, Santiago: Thomson Reuters, 2016, pp. 300 y ss.; también OSSANDÓN, María Magdalena, "Comisión por omisión del delito de favorecimiento de la prostitución de menores", en: La Ciencia Penal en la Universidad de Chile. Libro homenaje a los profesores del Departamento de ciencias penales de la Facultad de Derecho de la Universidad de Chile, Santiago: sin editorial, 2013, pp. 444 y ss.
} 
Polít. crim. Vol. 13, No 26 (Diciembre 2018) Art. 2, pp. 682-783.

[http://www.politicacriminal.cl/Vol_13/n_26/Vol13N26A2.pdf]

la necesidad de regresar a una teoría reformulada del deber jurídico. Las consecuencias que se siguen de este postulado regreso, sin embargo, se extraerán en un trabajo posterior y separado del presente, debido a la extensión que éste ya alcanza.

\section{Una revisión histórico-dogmática de los criterios de equivalencia entre delito de acción y de omisión}

El desarrollo moderno de la dogmática de la omisión impropia se encuentra marcado por el debate entre tendencias de orientación material, que imperan de manera avasallante en la doctrina, por un lado, y un pensamiento de orientación comparativamente más formal, atribuido a la jurisprudencia del Reichsgericht bajo el epígrafe de la teoría formal del deber jurídico, por el otro ${ }^{24}$.

En el umbral del siglo XX, esto es, justo en la época fundacional de la teoría general del delito, la doctrina, que parte mayoritariamente de la ausencia de causalidad en la omisión, sale no obstante en busca de la causalidad y de la acción previa a la omisión, con el fin de asentar una base común al delito de acción y de omisión. La jurisprudencia, por su lado, con sentido práctico y aparentemente con razón, parte simplemente de la premisa de la causalidad -sin adjetivos ni prefijos- en la omisión, asunción que le permite concentrarse en la cuestión de la exigencia adicional del deber. Este razonamiento puede observarse, a modo de ejemplo, en los siguientes casos extraídos de la jurisprudencia de ese prestigioso tribunal supremo.

\subsection{La teoría formal del deber jurídico en la jurisprudencia del Reichsgericht}

En un primer caso, un sujeto había perdido la vista a consecuencia de un accidente, por lo que le fue concedida una pensión de invalidez en 1899 -mediante resoluciones de enero y junio-, sin embargo, ya a principios de 1900 había recuperado la visión, pese a lo cual omitió solicitar la revocación de la pensión previamente otorgada. El tribunal supremo analiza la posible configuración del delito de estafa por ocultación de una circunstancia fáctica verdadera, para lo cual aclara que ésta no surge ya cuando la moral y las buenas costumbres obligan a su manifestación, sino que "solamente cuando existe una obligación fundada en el Derecho para ello" 25 . Al revisar las leyes sobre seguro de accidentes vigentes en la época, el tribunal constata que la revocación se contempla para el evento de un cambio significativo de las condiciones que hicieron necesaria la pensión, acreditado mediante un informe emitido por la respectiva asociación profesional, pero que, mientras no existiese un reporte formal, el sujeto no tenía el deber de presentar una solicitud con ese objeto. Es interesante observar como el tribunal, luego de descartar la configuración de un engaño por la sola

\footnotetext{
${ }^{24}$ Cfr. la detallada exposición de RUDOLPHI, Hans-Joachim, Die Gleichstellungsproblematik der unechten Unterlassungsdelikte und der Gedanke der Ingerenz, Göttingen: Otto Schwartz \& Co., 1966, pp. 9 y ss., 15 y ss., 20 y ss., 26 y ss.; también SCHÜNEMANN, Bernd, Fundamento y límites de los delitos de omisión impropia, Madrid/Barcelona: Marcial Pons, 2009, pp. 26 y ss., con acento en los diversos métodos usados por cada planteamiento dogmático; SILVA SÁNCHEZ, Jesús María, El delito de omisión, $2^{\mathrm{a}}$ ed., Montevideo/Buenos Aires: BdeF, 2003, pp. 25 y ss., 99 y ss., sobre los conceptos negativos y positivos de la omisión jurídico-penal.

${ }^{25}$ RGSt. 46, 28.01.1913, p. 415 (destacado agregado).
} 
ROJAS, Luis. "Delitos de omisión entre libertad y solidaridad".

circunstancia de recibir los pagos y emitir el recibo correspondiente, hace ver al tribunal de instancia que ya en el momento (1898) de solicitar la pensión existirían indicios de que el sujeto podría haber engañado a los médicos que emitieron los certificados correspondientes acerca de la persistencia de su estado de ceguera ${ }^{26}$.

En otro caso se trataba del novio de una embarazada a quien éste le había facilitado una jeringa con la cual ella se aseaba luego de sostener relaciones y mediante la que pretendía provocarse un aborto. El tribunal supremo aclara que no existía un "deber jurídico", pues los esponsales no tienen la fuerza para fundar derechos y obligaciones como el matrimonio, además de que "el incumplimiento de un mero deber 'moral' a la evitación de una acción delictiva tampoco es jurídico-penalmente relevante allí donde la evitación hubiese sido sin más posible mediante el cumplimiento del deber"27. No obstante, y nuevamente, el tribunal superior hace ver que el sujeto no ha permanecido simplemente pasivo, sino que ha favorecido activamente la maniobra abortiva mediante facilitación de la jeringa, por lo que podría responder como cómplice en la tentativa de aborto, aun cuando se haya comprobado, en el juicio, que dicha jeringa era completamente inapta para ser introducida en el útero de la embarazada y no podía de ninguna manera provocar el efecto buscado ${ }^{28}$.

En el tercer caso se trata de un incendio desencadenado en una casa-habitación que le pertenecía a la mujer del sujeto, respecto de la cual, sin embargo, éste había tomado un seguro en favor de la casa y sus pertenencias. El incendio había sido provocado de tal manera de generar la apariencia que provenía de un establo - de propiedad de una tercera personacolindante, a aproximadamente un metro de distancia, de la casa y que se había extendido luego a ésta, no obstante, se encontraron paja, ramas y papel mojado con petróleo al interior de esta última ${ }^{29}$. Existen indicios de que el sujeto podría haber provocado él mismo el incendio o al menos haber apoyado a que su cónyuge lo hiciera, o finalmente, en conocimiento del plan de la mujer, haber permanecido inactivo frente a la acción de ésta alternativas fácticas que permiten una "comprobación electiva" por parte del tribunal ("wahlweise Feststellung").

Al analizar la última alternativa, el tribunal recurre a los principios desarrollados por la jurisprudencia sobre "realización de hechos punibles comisivos mediante omisión", que rigen no solamente en los casos en los que el resultado antijurídico se ha producido "sin culpa" ("ohne Verschulden"), sino que también cuando el resultado ha sido realizado culpablemente por otro ${ }^{30}$ :

"presupuesto, empero, no es solamente que la inactividad fuera causal ("ursächlich") para el resultado, sino también que el sujeto tuviese el deber jurídico ("Rechtspflicht") de impedir el resultado antijurídico. El mero deber moral de intervenir no es suficiente [cita de jurisprudencia previa]. Si existe un deber jurídico de acción, ello deriva de los preceptos

\footnotetext{
${ }^{26}$ RGSt. 46, 28.01.1913, p. 416; vale decir, podría haber un engaño mediante acción y no simplemente uno "concluyente" o mediante omisión.

${ }^{27}$ RGSt. 56, 6.10.1921, p. 169; dicho en términos más sencillos, el deber no se sigue meramente del poder.

${ }^{28}$ RGSt. 56, 6.10.1921, p. 169 y s.; es decir, se trataba de una tentativa inidónea.

${ }^{29}$ RGSt. 64, 16.06.1930, p. 273.

${ }^{30}$ RGSt. 64, 16.06.1930, p. 274 y s.
} 
(“Geboten") expresos o tácitos del ordenamiento jurídico. Aquél puede tener su fundamento en una regla legal [cita de jurisprudencia], en la gestión de una empresa [cita de jurisprudencia], en un vínculo de empleado público [cita de jurisprudencia], o en un vínculo contractual [cita de jurisprudencia]. También el sujeto que mediante una actividad previa ha creado el peligro de realización de un resultado jurídicamente lesivo o ha vuelto inminente un peligro ya existente, se encuentra jurídicamente obligado a evitar el resultado, cuando tiene el poder para ello [cita de jurisprudencia]"31.

En el caso, la relación de causalidad entre la inactividad del sujeto y los dos incendios no fue detenidamente comprobada por el tribunal de instancia -jurado-, pero éste ha partido abiertamente de la premisa que al sujeto le hubiese sido muy fácil apartar a su mujer del hecho. Lo que falta en la sentencia de instancia, y que a continuación analiza el Tribunal supremo, es toda consideración acerca del segundo presupuesto de punibilidad de la "comisión mediante omisión", cual es la exigencia del deber jurídico de evitación, en este caso, de los incendios.

El tribunal analiza la existencia de tal deber del sujeto, primero, en relación al patrimonio de la compañía aseguradora y, luego, respecto de la propiedad de su cónyuge. En relación al primer deber, el tribunal parte aclarando que no existe un "deber jurídico general" de proteger la propiedad ajena frente a peligros -deber que tampoco surge de la entonces contravención de omisión de socorro del $\S 360$ N. 10 del Código penal alemán (en adelante, StGB). Cierto, existe el deber de denunciar el plan de cometer un crimen peligroso para la comunidad, según el $\S 139$ StGB -sobre delito de omisión de denuncia-, pero su incumplimiento no se encuentra castigado con la misma pena del crimen no impedido ${ }^{32}$. Sin perjuicio de ello, un deber jurídico de evitación surge de la relación contractual con el asegurador, aún sin un pacto específico al respecto. El asegurador asume la responsabilidad por los daños producidos a consecuencia de un incendio y su interés en evitar tales siniestros apenas puede salvaguardarlo por sí mismo. Por lo que asegurador debe y puede confiar en que el tomador del seguro al menos lo apoye evitando que un sujeto decidido a incendiar una cosa asegurada la destruya, cuando aquél se encuentra en condiciones de impedirlo, sin sufrir daños para sí mismo. Es lo que exige la buena fe en consideración a las buenas costumbres $-\S \S 157,242$ del Código civil alemán. Asimismo, tal deber jurídico se funda también en la ley de seguros, aun cuando no se encuentre expresamente contemplado. En este sentido, el asegurador queda liberado de la cobertura, cuando el tomador del seguro ha provocado dolosamente el siniestro. Además, éste se encuentra obligado, al momento de celebrar el contrato, a informar sobre las circunstancias por él conocidas que sean relevan-

\footnotetext{
${ }^{31}$ RGSt. 64, 16.06.1930, p. 275 y s. (destacado e inserciones agregados); la premisa de que no es suficiente un deber moral, dubitativa al comienzo de la jurisprudencia (RGSt. 30, 29.05.1897, p. 125: "un deber jurídico o moral"), parece asentarse en RGSt. 40, 11.05.1907, p. 166 ("necesidad de una estricta diferenciación entre infracciones de un deber jurídico [....] y lesiones de un deber moral [....]") y vuelve a desestabilizarse recién en RGSt. 69, 10.09.1935, p. 323 ("responder bilateralmente por el otro es un mandato de la moral, que deriva más ampliamente del deber cristiano de amor al prójimo y, en el ámbito más restringido de la camaradería de los soldados en el frente, del nacionalsocialismo, que exige disposición al sacrificio dentro de la comunidad del pueblo. El deber moral puede convertirse en jurídico para las personas que frente al mundo exterior aparecen tan unidas en una estrecha comunidad de vida, como es el caso de la familia o del hogar común").

${ }^{32}$ RGSt. 64, 16.06.1930, p. 276.
} 
ROJAS, Luis. "Delitos de omisión entre libertad y solidaridad".

tes para la asunción del riesgo. Y, después de la celebración del contrato, también debe informar sobre circunstancias sobrevinientes que incrementen dicho riesgo. De estas disposiciones se deriva el deber jurídico, no sólo de omitir la provocación intencional del incendio, sino también de evitar voluntariamente tolerar la provocación del mismo por otro sujeto. Este deber jurídico ha sido infringido por el sujeto, al dejar que su mujer provocase el incendio de la casa-habitación. Mediante la omisión de la intervención posible y exigida por el deber, se ha vuelto responsable del delito de incendio como coautor, siempre que también se configure el aspecto interno del tipo ${ }^{33}$.

Para el evento de que en el nuevo juicio se comprobase que ha sido un tercero quien ha provocado el incendio, el Tribunal supremo analiza un segundo deber jurídico, esta vez en relación a la propiedad del cónyuge, que derivaría del $\S 1353$ del Código civil alemán (en adelante, BGB), norma que obliga recíprocamente a los cónyuges a la vida común. Este deber comprende la confianza y la ayuda recíprocas: "este deber surgido de la ley moral ("Sittengesetz") ha sido erigido por el $\S 1353$ BGB en un deber jurídico", del cual se sigue, a su vez, el deber de resguardar la propiedad del cónyuge ${ }^{34}$.

Finalmente, en otro caso, en el cual también el novio de una embarazada, pero esta vez ya ante los signos de comienzo del parto, la conduce a un lugar despoblado donde ésta pare a una criatura, a la que luego ambos dejan en la tierra por el lapso de varias horas hasta que muere de frío, el Tribunal supremo analiza los dos requisitos de la relación de causalidad ("der ursächliche Zusammenhang") y de la "antijuridicidad" ("Rechtswidrigkeit"). En cuanto a la causalidad, ésta se verifica por la circunstancia de que el niño hubiese sobrevivido si el sujeto, en vez de partir "a campo traviesa" ("aufs freie Feld"), hubiese ido a otra casa o simplemente recurrido a la ayuda de una tercera persona, a fin de darle a una criatura recién nacida los cuidados correspondientes, para todo lo cual el sujeto se encontraba en condiciones fácticas de hacerlo. No obstante, el sujeto omitió esta acción que podía realizar y que en caso de haberse realizado habría evitado la muerte del niño. Y no quiso realizarla por el temor que le provocaba la carga que habría tenido que asumir de haber sobrevivido la criatura $^{35}$.

La "antijuridicidad de la omisión causal del resultado de muerte del niño" se funda en dos circunstancias. En primer lugar, en la circunstancia de haber provocado el estado en el cual se pudo desarrollar la condición para la muerte del niño, en cuanto éste fuera expulsado del vientre materno. Le correspondía al sujeto hacer lo posible para que la condición no se hiciera efectiva. Este deber tiene su base no solamente en lo exigido por la humanidad y la "costumbre vital" ("Lebensbrauch"), sino que ya en los preceptos incorporados por la prohibición de la lesión a la vida, la integridad física y la salud de otro ${ }^{36}$. Pero además, independientemente de dicha circunstancia, el deber jurídico deriva de la norma del $\S 221$ StGB, que prohíbe el abandono en un lugar solitario de una persona que se encuentra bajo cuidado por una situación de desamparo derivada de su constitución física. La parturienta se encontraba bajo el resguardo ("Obhut") del sujeto ya desde el comienzo del parto y

\footnotetext{
${ }^{33}$ RGSt. 64, 16.06.1930, p. 277 y s.

${ }^{34}$ RGSt. 64, 16.06 .1930 , p. 278 y s.

${ }^{35}$ RGSt. 66, 4.01.1932, p. 72.

${ }^{36}$ RGSt. 66, 4.01.1932, p. 72 y s.
} 
luego en el momento de nacimiento de la criatura, al haberla alejado - a la parturienta- de otros en su situación de necesidad y sometido a su propio resguardo. Este se extendió a la criatura, en tanto ésta al nacer se encontraba en una situación de necesidad mayor que la madre $^{37}$. El fundamento de este deber no se limita al ámbito de la moral, sino que, por el contrario, se remonta ya al principio jurídico contenido en el art. 132 de la "ordenanza judicial criminal" del emperador Carlos V - "Carolina"- que obligaba a la protección de los niños de corta edad y a prestarle la ayuda necesaria al desamparado para la conservación de su vida e integridad. Por ende, el Derecho, y no solamente la moral, reprueba la negación del sujeto a tomar al niño bajo su resguardo ${ }^{38}$.

\subsection{Valoración de la jurisprudencia reseñada}

Esta larga reseña jurisprudencial llama la atención por varias razones. La primera es que la jurisprudencia recae en casos que superan con creces el ámbito restringido de los tipos de homicidio y lesiones corporales, los cuales sirven regularmente de ejemplo en la doctrina que se ocupa de la "comisión por omisión". Lo otro es que en prácticamente todos los casos la distinción entre acción y omisión es muy sutil. El Reichsgericht no parece asignarle a esta distinción el mismo alcance que la doctrina. Y cuando este tribunal parte del supuesto que el reproche se funda en una omisión, analiza la concurrencia de dos requisitos copulativos para justificar el castigo a título del correspondiente delito de acción ${ }^{39}$.

En primer lugar, verifica la relación de causalidad entre la omisión y el resultado lesivo ${ }^{40}$. Es decir, no se refiere a un nexo de "cuasi-causalidad" o de "causalidad hipotética", como suele hacerse en la doctrina. Simplemente habla de causalidad, presupone, entonces, que existe tal relación entre omisión y resultado antijurídico ${ }^{41}$. Este nexo se establece mediante

${ }^{37}$ RGSt. 66, 4.01.1932, p. 73.

${ }^{38}$ RGSt. 66, 4.01.1932, p. 73 y s.

${ }^{39}$ Además, exige culpabilidad, en la forma de dolo o culpa; el análisis siguiente, empero, se restringe a la faz objetiva del hecho punible.

${ }^{40}$ En este sentido, es muy notable leer el siguiente voto especial redactado por Pedro ORTIZ en un fallo de la Corte de Apelaciones de Talca de 30.10.1931, en: Revista de Derecho y jurisprudencia, t. XXIX, marzo-abril (1932), no 1 y 2, p. 7 y s.: “Acción es el movimiento corporal trascendente al mundo exterior, es decir, que produce o que puede producir una mutación en el mundo que rodea al actor; omisión es la no actuación trascendente al mundo externo, es decir, consiste en no impedir una mutación o cambio que ha podido y debido impedirse (...). El cambio o mutación en la situación externa que causa la acción o que se produce por no haberse impedido a causa de la omisión, es lo que se llama resultado. La acción y el resultado son materialidades perceptibles por los sentidos y si están en relación de causa a efecto, constituyen el hecho, que es otra materialidad" (destacado original).

${ }^{41}$ En la doctrina moderna, de segunda mitad del siglo XX, así también SPENDEL, Günter, „Zur Dogmatik der unechten Unterlassungsdelikte“, Juristenzeitung $\mathrm{n}^{\circ}$ 5/6 (1973), pp. 137 y ss.; PUPPE, Ingeborg, "Der Erfolg und seine kausale Erkärung im Strafrecht", Zeitschrift für die gesamte Strafrechtswissenschaft (ZStW) vol. 92 (1980), pp. 895 y ss., 899 y ss.; VOGEL, Joachim, Norm und Pflicht bei den unechten Unterlassungsdelikten, Berlin: Duncker \& Humblot, 1993, pp. 146 y ss., 156 y ss.; dubitativo, HERZBERG, Rolf-Dietrich, „Die Kausalität beim unechten Unterlassungsdelikt“, Monatsschrift für Deutsches Recht, $\mathrm{n}^{\circ} 11$, 1971, pp. 881 y ss., y EL MISMO, Die Unterlassung im Strafrecht und das Garantenprinzip, Berlin/New York: De Gruyter, 1972, p. 204 y s., donde la causalidad constituye un elemento no necesario de la evitabilidad; en contra, KAUFMANN, Dogmatik der Unterlassungsdelikte, cit. nota n 17, pp. 60 y ss., 202 y s. (respecto del delito propio de omisión), aunque, en un pasaje bastante enigmático, matiza la tesis reconociendo la existencia de causalidad entre la omisión de la acción y el acontecimiento, mas no entre 
ROJAS, Luis. "Delitos de omisión entre libertad y solidaridad".

la constatación de la posibilidad cierta de evitación del resultado lesivo en el caso de que el sujeto hubiese realizado -hipotéticamente- la acción impeditiva y, además, se hubiese encontrado en condiciones fácticas para realizarla -capacidad de realización de la acción impeditiva.

En segundo lugar, exige la concurrencia adicional de un deber jurídico y su infracción. Sobre el punto, es interesante observar como el tribunal supremo busca siempre alguna fuente del deber jurídico precisamente para deslindarlo de un mero deber moral o ético. Si se observa bien, el procedimiento de búsqueda consiste en extraer un deber jurídico de una fuente formal, cuestión que se nota, por ejemplo, en el caso de la estafa de seguro mediante omisión frente al incendio, donde el tribunal funda un deber de evitación, aun cuando éste no se encuentre expresamente contemplado en el texto del contrato o de la ley, en ese caso, de seguros. Por otra parte, entre las fuentes que originan el deber jurídico reconoce a la injerencia, aunque no la llame explícitamente así. Además, en el último caso reseñado sobre “infanticidio por omisión”, el Reichsgericht extrae el deber jurídico de evitación de las normas que prohíben el abandono de personas desvalidas, esto es, de una ley penal.

Lo anterior permite sacar dos conclusiones provisionales. La primera es que la teoría del deber jurídico, en la versión sostenida por esta jurisprudencia, no es tan formal como parece. Pues, se trata siempre de extraer un deber jurídico a partir de una fuente formal, pero aquél no es idéntico con ni se reduce a ésta ${ }^{42}$. La segunda es que las fuentes posibles del deber de evitación, si bien son siempre jurídicas, no se agotan en fuentes de carácter pre- o extrapenales.

\subsection{La teoría de la interferencia y el principio de la actividad previa en la doctrina}

La premisa de la causalidad de la omisión, de la cual parte la jurisprudencia de la época, es puesta en cuestión por la doctrina desde diversos frentes. Estos pueden agruparse bajo los planteamientos que, por un lado, giran en torno a la teoría de la interferencia y, por el otro, refieren la causalidad a una acción previa del sujeto -de ahí: principio de la actividad previa.

Uno de los principales representantes de la teoría de la interferencia es el propio von Buri. Según este autor, la decisión adoptada de evitar la acción de un eventual resultado jurídicopenal coloca un impedimento a la realización de ese resultado, de tal forma que si después, cuando la acción realmente amenaza con ser causal, esa voluntad inicial de evitar el resul-

sujeto y acción omitida (¿?); en contra también, WELZEL, Hans, Das Deutsche Strafrecht, 11. ed., Berlin: De Gruyter, 1969, p. 200 y s.; cfr. SILVA SÁNCHEZ, El delito de omisión, cit. nota no 24, pp. 293 y ss.; GIMBERNAT, Enrique, Estudios sobre el delito de omisión, 2a ed., Montevideo/Buenos Aires: BdeF, 2013, pp. 386 y ss.

${ }^{42}$ Cfr. BÖHM, Alexander, Die Rechtspflicht zum Handeln bei den unechten Unterlassungsdelikten, Frankfurt a.M.: sin editorial, 1957, p. 56 y s., cuando trata el deber jurídico surgido de la ley, aclara que tal deber se funda no en el precepto legal sino que en la norma que le subyace ("El deber jurídico surge de la norma. Se conoce el contenido de la norma a partir de los preceptos legales en los cuales ésta se refleja"); en cuanto al deber jurídico surgido de un contrato, observa BÖHM, Diss., cit. nota ${ }^{\circ} 42$, p. 75 y s., que el fundamento jurídico del deber de evitación no es el contrato en sí, sino que la asunción voluntaria de la protección a un bien jurídico. 
Polít. crim. Vol. 13, No 26 (Diciembre 2018) Art. 2, pp. 682-783.

[http://www.politicacriminal.cl/Vol_13/n_26/Vol13N26A2.pdf]

tado se torna en su opuesta, esta transformación implica la anulación de dicho impedimento y con ella la causación del resultado ${ }^{43}$. Como se puede observar, este planteamiento lo que hace es internalizar la causalidad de la omisión.

Sin embargo, al menos en una versión ulterior de la teoría, es interesante observar como se incorpora un elemento normativo al proceso de transformación descrito. El aspecto normativo surge para explicar el impedimento, ya que éste subiste por el deber de obediencia. En la medida en que el sujeto es consciente de este deber, se siente inmediatamente exigido a un comportamiento adecuado al mismo, exigencia que se ve suprimida cuando el sujeto adopta expresamente la decisión de ser desobediente. Es la consciencia del deber de evitar el resultado, entonces, la que coloca el impedimento para su realización, de tal manera que la supresión de éste -interferencia- o incluso la consideración de motivos que provocan un comportamiento desacertado en contravención a la consciencia del deber, es la acción mediante la cual se le quita eficacia a la consciencia del deber. La causalidad de esta acción radica en la posibilitación del resultado producida mediante la anulación de un impedimento que habría hecho fracasar el resultado ${ }^{44}$. Von Buri aclara que la consciencia del deber no necesita de una actividad previa que favorezca la realización del resultado para surgir, sino que puede nacer directamente de un precepto legal, pero que normalmente tendrá como presupuesto tal favorecimiento efectivo del resultado, sin que éste sea requisito necesario para aquélla ${ }^{45}$.

Es precisamente en la discusión acerca de esa última exigencia donde se separan los otros planteamientos de la doctrina que, junto con rechazar la premisa de la causalidad de la omisión, ofrecen un fundamento distinto al de la teoría de la interferencia.

El representante más prominente de esta tendencia es Adolf Merkel. El punto de partida reside en la premisa de que la "responsabilidad jurídica general" existe sólo por aquello que se provoca de manera imputable en la esfera jurídica de un tercero. Entonces, para ser responsable por no haber favorecido o evitado aquello que sucede en el círculo de intereses de otro se requiere de un fundamento jurídico especial ${ }^{46}$. La diferencia entre ambas clases de responsabilidad no deriva de la forma de la conducta antijurídica como tal, sino que de la diversa naturaleza de las exigencias jurídicas puestas por el Estado ${ }^{47}$. Así, la exigencia que subyace a los delitos comisivos se restringe a un "non laede", por lo que la realización de éstos se dirige a un efecto positivo, consistente en una modificación al interior del círculo de intereses de un tercero, que no habría ocurrido sin la actividad correspondiente del delincuente. Por ende, aquí la exigencia jurídica es de carácter negativo y su contravención da origen a un injusto positivo. En cambio, en los delitos de omisión, la exigencia jurí-

\footnotetext{
${ }^{43}$ VON BURI, Maximiliam, "Die Kausalität der Unterlassung”, Zeitschrift für die gesamte Strafrechtswissenschaft (1881), p. 400 y s.

${ }^{44}$ VON BURI, "ZStW 1881", cit. nota n' 43, p. 410 y s.

${ }^{45}$ VON BURI, “ZStW 1881", cit. nota $\mathrm{n}^{\circ} 43$, p. 411.

${ }^{46}$ MERKEL, Adolf, "Von den Unterlassungsverbrechen, beziehungsweise dem negativen Unrechte, und ihrem Gegensatz, und von dem Verhältnisse der ersteren zu den Polizeivergehen”, en: Kriminalistische Abhandlungen, t. II, Leipzig: Breitkopf und Härtel, 1867, p. 77.

${ }^{47}$ MERKEL, Abhandlungen, cit. nota ${ }^{\circ}$ 46, p. 78; algún tiempo después -del Código penal del Reich, EL MISMO, Lehrbuch des deutschen Strafrechts, Stuttgart: Ferdinand Enke, 1889, p. 38.
} 
ROJAS, Luis. "Delitos de omisión entre libertad y solidaridad".

dica es de carácter positivo y su contravención implica un injusto negativo, en tanto el tercero no recibe la modificación requerida ${ }^{48}$.

Según A. Merkel, sólo se puede hablar de delitos comisivos allí donde la modificación lesiva al interior de la esfera jurídica de alguien tiene su causa efectiva en la conducta de un tercero. Esta causa no puede derivar de una conducta puramente pasiva, de modo que alguna actividad efectiva realizada con conocimiento y voluntad por el sujeto debe estar presente para poder hablar de un causante de esas modificaciones lesivas ${ }^{49}$. La ausencia de una acción no puede producir efectos positivos, pues éstos presuponen algo efectivo. Por consiguiente, para que pueda configurarse un delito comisivo, la causa del resultado no puede ser vista en la omisión misma, sino que en una conducta activa que puede lesionar intereses jurídicamente protegidos, en caso de que luego no se realicen ciertas acciones de las cuales depende que no se produzcan tales consecuencias dañosas ${ }^{50}$.

Sobre estas premisas, tanto normativas como descriptivas, A. Merkel formula el principio de la actividad previa como presupuesto del castigo de la comisión por omisión. Según este principio, el sujeto sólo puede ser responsable a ese título, si la "integridad de los intereses de otro" se ha vuelto dependiente, de modo imputable, a la realización previa de la acción correspondiente del sujeto ${ }^{51}$. Por ejemplo, el que anima a un nadador inexperimentado a introducirse en la tormenta por la vía de asegurarle su apoyo y luego no cumple intencionalmente su compromiso, responde por la muerte del nadador ${ }^{52}$. La formulación del principio se precisa en el sentido de que hay una causación criminal solamente cuando mediante una conducta activa se ha hecho dependiente la integridad del otro, de modo imputable, de cualesquiera condiciones positivas o negativas, las cuales luego el sujeto omite producirlas. Tal como el resultado externo, la lesión del otro, no se produce mediante la omisión, sino que por la causación previa, así también la imputación del resultado se funda no en la omisión misma, sino que como una derivada eventualmente de esa causación ya efectiva $^{53}$.

Ante la pregunta por la exigencia de un deber jurídico como presupuesto de la punición, A. Merkel responde que la omisión de una determinada actividad efectiva sólo puede hacernos responsables por la realización de una lesión, si aquella ha hecho surgir un deber mediante

\footnotetext{
${ }^{48}$ MERKEL, Abhandlungen, cit. nota $\mathrm{n}^{\circ} 46, \mathrm{p} .79$.

${ }^{49}$ MERKEL, Abhandlungen, cit. nota $\mathrm{n}^{\circ} 46, \mathrm{p} .79$ y s.

${ }^{50}$ MERKEL, Adolf, Lehrbuch, cit. nota $\mathrm{n}^{\circ}$ 47, p. 113 y s.; „como causa del resultado debe verse en estos delitos la conducta activa con inclusión de las propiedades que resultan de ella posteriormente, no en sí la omisión. Una no acción como tal no puede producir efectos; efectos presuponen algo efectivo y éste no puede hallarse en fuerzas que no existen o que no ocurren ni en la esfera de la acción humana ni en la de los acontecimientos mecánicos" (p. 114).

${ }^{51}$ MERKEL, Abhandlungen, cit. nota ${ }^{\circ} 46$, p. 81 y s.

${ }^{52}$ MERKEL, Abhandlungen, cit. nota $\mathrm{n}^{\circ}$ 46, p. 83; se encuentre decidido o no desde un principio a esa deslealtad, pues la imputabilidad de la lesión no se ve alterada, al constar independientemente tanto el nexo objetivo de causalidad entre ella y esa acción positiva como la previsibilidad de la consecuencia de esta última (p. 83).

${ }^{53}$ MERKEL, Abhandlungen, cit. nota n ${ }^{\circ} 46$, p. 87.
} 
Polít. crim. Vol. 13, No 26 (Diciembre 2018) Art. 2, pp. 682-783.

[http://www.politicacriminal.cl/Vol_13/n_26/Vol13N26A2.pdf]

nuestra actividad previa, de modo que la causación criminal no se funda en el deber jurídico, sino que, por el contrario, éste deriva de la eventual causación criminal ${ }^{54}$.

En la misma época, el jurista austríaco Julius Glaser toma el mismo principio de la actividad previa como punto de partida, pero diferencia de modo más claro un segundo grupo de $\operatorname{casos}^{55}$. Se trata de casos en los que la relación entre la actividad previa y el daño se encuentra mediada por el acto de un sujeto que podría prevenirlo. Según Glaser, la sola circunstancia de que el comportamiento de un sujeto cumple o no sus deberes, no altera en nada la configuración objetiva de la conducta ${ }^{56}$. El comportamiento de un hombre no es menos dañino por la circunstancia de ser adecuado al derecho de ese sujeto como tampoco puede volverse al revés más perjudicial porque conforme al juicio de un jurista se califique de contrario a Derecho ${ }^{57}$. Por ejemplo, en una variante del caso del nadador, en la que éste es, además de inexperimentado, miedoso y se mete en el río, porque $\mathrm{B}$, cuya destreza es conocida por el nadador, le promete quedarse y apoyarlo, en caso necesario, incumpliendo luego B su promesa y dejándolo correr el peligro. Según Glaser, B responde por la eventual muerte, porque su promesa de prestarle ayuda fue la que condujo al nadador a exponerse al peligro. La asunción de una determinada obligación de su parte fue uno de los presupuestos de la realización del peligro, no solamente porque no haya impedido el resultado, sino porque lo ha posibilitado ${ }^{58}$.

Así, Glaser llega a la siguiente conclusión: bajo ciertas circunstancias, el comportamiento de un sujeto funda en otros el supuesto de que va a realizar ciertos actos necesarios frente a un peligro actual o inminente. Este supuesto conduce luego ya sea a actividades por las cuales uno se expone a un peligro o bien aparta a otros de actuar efectivamente contra éste. Si el sujeto no cumple ese supuesto, omite lo que se espera de él, de modo tal que no solo no ha disminuido el peligro, sino que lo ha incrementado ${ }^{59}$.

En sintonía con esta premisa, Glaser se refiere a continuación al caso de la madre que deja morir a su hijo mediante omisión de la ayuda necesaria inmediatamente después del parto ${ }^{60}$. En general, los padres se encuentran obligados a alimentar a su hijo. La sola falta de cuidado no permite afirmar que lo han matado, pues no han favorecido el curso natural de los acontecimientos. Se pregunta: ¿han contribuido a la producción del resultado más que el vecino que primeramente pasa de largo de la casa? Responde: han dejado, al igual que éste, morir al niño, por lo que no han causado la muerte ${ }^{61}$. Como criterio de solución propone

\footnotetext{
${ }^{54}$ MERKEL, Abhandlungen, cit. nota no 46, p. 88 y s., aunque luego reconoce algunas excepciones (pp. 89 y Ss.).

55 GLASER, Julius, Abhandlungen aus dem örsterreichischen Strafrecht, t. I, Wien: Hendler \& Comp., 1858, pp. 293 y ss.; para la verificación del nexo de causalidad, debe suprimirse al creador u hombre de la suma de los acontecimientos, de tal modo que si el resultado desaparece, puede considerarse que éste es una consecuencia de su actividad (p. 298).

${ }^{56}$ GLASER, Abhandlungen, cit. nota n ${ }^{\mathrm{o}}$ 55, p. 307 y s.

${ }^{57}$ GLASER, Abhandlungen, cit. nota n ${ }^{\mathrm{o}}$ 55, p. 308 y s.

${ }^{58}$ GLASER, Abhandlungen, cit. nota $\mathrm{n}^{\mathrm{o}}$ 55, p. 312 y s.

${ }^{59}$ GLASER, Abhandlungen, cit. nota ${ }^{\circ}$ 55, p. 317.

${ }^{60}$ GLASER, Abhandlungen, cit. nota $n^{\circ} 55$, pp. 318 y ss.

${ }^{61}$ GLASER, Abhandlungen, cit. nota n ${ }^{\mathrm{o}} 55$, p. 320 y s.
} 
ROJAS, Luis. "Delitos de omisión entre libertad y solidaridad".

atender a la circunstancia de haber asumido el cuidado del niño, excluyendo a otros de actuar. Aquel que asume de esta manera el cuidado, produce mediante su hacer positivo un estado en el cual basta la omisión para volver inevitable la muerte del niño ${ }^{62}$.

\subsection{Crítica a la teoría de la interferencia y al principio de la actividad previa}

Tanto la teoría de la interferencia como el principio de la actividad previa tienen en común que niegan la causalidad de la omisión, es decir, justamente la premisa de la cual parte la jurisprudencia de la época. Pero, como el delito comisivo exige causalidad, y aquí se trata de la punición de la omisión a título de comisión -comisión por omisión-, entonces ambos planteamientos salen en busca de la causalidad más allá de la omisión misma. Lo que gatilla esta intensa búsqueda, sin embargo, es la imagen que la doctrina de la época tiene acerca de la relación causal. La doctrina maneja un concepto de causalidad eficiente, esto es, en que el plexo de condiciones es visto como un campo de fuerzas que produce el fenómeno del resultado ${ }^{63}$. Y la omisión como tal se aparta de esa imagen de la causalidad, en consecuencia, ambos planteamientos teóricos buscan las fuerzas productivas del resultado fuera de la omisión.

La búsqueda común se explica por la premisa compartida de la cual parten. Los derroteros seguidos por ambas teorías para encontrar la causalidad, empero, divergen. Por un lado, la teoría de la interferencia recurre al fuero interno del sujeto, adentro del cual se desata un conflicto de fuerzas psicológicas que produce indirectamente el resultado -causalidad interna. Por el otro, según el principio de la actividad previa, el campo de fuerzas productivas se ubica en la realización efectiva de una acción previa del sujeto -causalidad externa.

Pues bien, la teoría de la interferencia ha sido criticada por partir de la ficción de una decisión interna del sujeto en orden a evitar el resultado, cuando más bien debería suponerse una actitud de total indiferencia o incluso de simpatía con el daño ${ }^{64}$. Aún si el sujeto ha adoptado la decisión de intervenir en el curso de los acontecimientos, lo cierto es que, mientras esa decisión no se realice, ésta no puede calificarse de una condición impeditiva del resultado. Por lo tanto, el abandono de esa decisión tampoco constituye una supresión de tal condición. No es otra cosa que el abandono de otra decisión, que se aparta de la original, esto es, un acontecimiento puramente interno, carente de relevancia en el mundo exterior $^{65}$.

${ }^{62}$ GLASER, Abhandlungen, cit. nota $\mathrm{n}^{\circ} 55$, p. 321 y s.

${ }^{63}$ Sobre el contraste entre un concepto de causalidad eficiente (productiva) y de causalidad explicativa (lógica), recientemente muy claro MAÑALICH, Juan Pablo, Norma, causalidad y acción, Madrid/Barcelona: Marcial Pons, 2014, pp. 48 y ss., 52 y ss.

${ }^{64}$ TRAEGER, Ludwig, "Das Problem der Unterlassungsdelikte im Straf- und Zivilrecht", en: Festgaben für Ludwig Enneccerus, Marburg i.H.: Elwert'sche Buchhandlung, 1913, p. 18 y s.

${ }^{65}$ TRAEGER, “Das Problem”, cit. nota n 64, p. 55, crítica de la versión de la teoría de la interferencia sostenida por Binding en la primera edición del tomo II de su obra capital, versión en todo caso abandonada en BINDING, Karl, Die Normen und ihre Übertretung, t. II, 1. parte, 2. ed., Leipzig: Scientia Verlag (Aalen), 1914, p. 103 y s., p. 536 y s.; sin embargo, BINDING, Die Normen, cit. nota $\mathrm{n}^{\text {o }}$ 65, pp. 521 y ss., la reformulación que luego ofrece se traduce en una proyección externa del mismo campo de fuerzas que, según la teoría de la interferencia, sucede en el fuero interno del sujeto; define "causación" como "la producción, mediante la voluntad humana, de un peso mayor de las condiciones positivas por sobre las negativas del 
Esa crítica revela el mayor problema que aqueja a esta teoría, cual es la extrema internalización de la conducta del sujeto que propone, a tal punto de ver en la supresión del impedimento la acción mediante la que se desencadena la realización del resultado, al adoptar aquél la decisión contraria de no evitarlo. Dicho con otras palabras, el curso causal proviene de una acción interna del sujeto que consiste en una decisión que neutraliza otra previa de no realización del resultado. La teoría de la interferencia ubica la causalidad de la omisión en un campo de fuerzas psicológicas, al interior del cual una fuerza negativa, colocada por la decisión de no realizar el resultado, se ve neutralizada, en el momento crítico, por una fuerza positiva, surgida de la decisión de no evitar más su realización, con la consecuencia de la realización efectiva del resultado. En definitiva, éste es realización de la supresión interna del impedimento previo también interno.

La explicación normativa que luego ofrece esta misma teoría del proceso interno conlleva una cierta externalización del mismo. Pues, el deber de obediencia, en cuyo cumplimiento el sujeto se coloca el dique interno de contención a la realización del resultado, es externo al sujeto. No se trata de un deber distinto de aquel que surge de la propia norma de comportamiento respectiva, impuesta por el ordenamiento jurídico ${ }^{66}$. Por cierto, la efectividad de la norma depende de su capacidad motivadora del sujeto. Pero, la forma en que las normas de un ordenamiento jurídico orientan el comportamiento del ciudadano se limita a la fijación de una pauta externa de conducta, que recorta el ámbito posible de juego del sujeto, ya sea mediante la prohibición de realizar una acción o mediante la orden de ejecutar también una acción -mandato. No es presupuesto del cumplimiento del deber de obediencia su internalización así como tampoco es requisito de la infracción de la norma su conocimiento previo. El error de von Buri radica en internalizar el paso del cumplimiento a la infracción del deber de obediencia como explicación del origen causal de la comisión por omisión.

Frente a la teoría de la interferencia, la virtud de los planteamientos tanto de Glaser como de Merkel reside precisamente en externalizar dicho origen. Esto se traduce en el principio de la actividad previa.

La formulación de este principio responde a la necesidad de explicar el carácter criminal de la omisión. Dado que se parte de la premisa de un Derecho penal a su vez basado en el principio del "neminem laedere", principio que se ve amagado por la realización de una acción, entonces la omisión, para que pueda ostentar el mismo carácter criminal, debe reconstruirse en los términos de una acción que produce el mismo efecto - no basta un mero "injusto negativo". Es por esta razón que A. Merkel recurre al criterio de la dependencia del círculo de intereses del otro - esfera jurídica-, respecto de la acción previa del sujeto. Es decir, la omisión adquiere carácter criminal -amaga también el "neaminem laede"-, en

resultado" (p. 492, destacado agregado; cfr. EL MISMO, Die Normen, t. I, 4. ed., Leipzig: Scientia Verlag (Aalen), 1922, p. 116); dicha causación es posible mediante omisión por la "neutralización voluntaria de la hasta entonces inhibición voluntaria de esas causalidades, esto es, liberación de sus fuerzas antes retenidas por la voluntad contraria" (p. 557).

${ }^{66} \mathrm{Cfr}$. el concepto de norma formulado en la época por BINDING, Karl, Die Normen, t. I, cit. nota $\mathrm{n}^{\mathrm{o}}$ 65, p. 7, 45, pp. 96 y ss., 108 y ss., p. 134, p. 255 y s. 
ROJAS, Luis. "Delitos de omisión entre libertad y solidaridad".

tanto existe una acción previa del sujeto que ha vuelto dependiente, de un modo imputable, la integridad del otro respecto de dicha conducta. En esa medida, esto es, en tanto existe no sólo una omisión, sino también tal acción previa, puede afirmarse la causación del resultado, i.e. la lesión a dicha integridad. En su formulación sintética, cuando mediante una conducta activa se ha hecho dependiente la integridad del otro, de modo imputable, de cualesquiera condiciones positivas o negativas, las cuales luego el sujeto omite producirlas.

Allí radica el error fundamental de esta teoría. El error se explica por el concepto precario de causalidad sostenido por la doctrina de la época - segunda mitad del siglo XIX. En dicha formulación sintética, cabe preguntarse por la clase de condiciones que se enuncian de modo disyuntivo. Pues, si la condición positiva se entiende en el sentido de una fuerza que produce un efecto, entonces la omisión de su producción no realiza el resultado y, por ende, no hay lesión a la integridad del otro. Y si la condición negativa se entiende en el mismo sentido de una fuerza que esta vez impide un efecto, entonces la omisión de producir la fuerza negativa condiciona el resultado, esto es, el efecto contrario. Como se puede observar, la formulación sintética del principio considera equivalentes clases de condiciones de signo opuesto. En esta versión de la teoría, la acción previa, exigida para el castigo de la omisión, se dirige tanto a la producción como a la evitación del resultado.

En la primera configuración de la acción previa -dirigida a la producción del resultado-, no resulta comprensible por qué se exige adicionalmente la omisión como presupuesto del castigo ni tampoco cómo ésta, que se tilda previamente de una nada, pudiera sumar algo a la acción positiva previa ${ }^{67}$. En la segunda forma de la acción previa, esto es, de aquella dirigida a la evitación del resultado mediante asunción, resulta bastante problemático que la responsabilidad quede condicionada a que efectivamente se haya apartado a otros de realizar una acción impeditiva. Por ejemplo, la responsabilidad del funcionario encargado de vigilancia en una fábrica por el resultado dañoso, mal puede quedar excluida por la circunstancia de que no había otra persona idónea en ausencia suya. Tampoco puede ser requisito que mediante la asunción de tal labor se conduzca a otro a exponerse al peligro ${ }^{68}$. Si se trata de una persona previamente obligada y, además, se afirma que es el propio sujeto quien favorece el peligro, entonces, con mayor razón incumple su obligación.

La diferenciación del segundo grupo de casos, trazada ya antes por Glaser, en el que el sujeto obligado genera la confianza en otros de que va a intervenir frente al peligro, supuesto que luego conduce a la víctima a exponerse al mismo o que aparta a otros de intervenir, no subsana el error fundamental reseñado. Según dicho autor, en tal caso el sujeto mediante su asunción hace posible el resultado, esto es, no disminuye el peligro, sino que lo incrementa.

Mas una teoría que para salvar su principio se ve obligada a sostener que, por ejemplo, la asunción efectiva del cargo de guardavías, con la mejor intención, constituye un peligro para el funcionamiento del tren, se ajusticia a sí misma, tal como remata Traeger ${ }^{69}$. Agrega Binding que la colocación del personal de guardavías rige en general y que, por el contra-

\footnotetext{
${ }^{67}$ Cfr. TRAEGER, "Das Problem", cit. nota no 64, p. 34; crítico también BINDING, Die Normen, t. II, $1^{\text {a }}$ parte, cit. nota $\mathrm{n}^{\circ} 65$, p. 535 : "pues, cuando se agrega nada a algo, éste permanece tal cual".

${ }^{68}$ Cfr. TRAEGER, "Das Problem", cit. nota n ${ }^{\circ}$ 64, p. 35.

${ }^{69}$ TRAEGER, "Das Problem", cit. nota n ${ }^{\circ}$ 64, p. 38.
} 
rio, configura una garantía contra los peligros que asechan al tren, antes bien contiene, en vez de un peligro, una disminución del mismo ${ }^{70}$. En breve, esa teoría confunde al médico con la causa de la enfermedad ${ }^{71}$. Y así profundiza el error en el que incurre el principio de la actividad previa. Pues, no sólo considera equivalentes, sino que confunde las fuerzas positivas con las negativas del resultado.

\subsection{Teoría formal del deber jurídico en la doctrina}

En el contexto de la discusión entre doctrina y jurisprudencia, se oyen algunas voces que se sitúan más bien en la línea de la jurisprudencia. Así, Paul Merkel se refiere a la causalidad de la omisión, en tanto se presentan dos acontecimientos que en su secuencia aparecen ante el pensamiento como causa y resultado. Aunque como tal, la omisión, algo solamente representado, que no se encuentra presente, no es realmente causal ${ }^{72}$.

En un sentido similar, Traeger compara los casos de causación de la no evitación del resultado con la mera no evitación del resultado. En aquel grupo de casos, el sujeto coloca una condición positiva a la condición negativa del resultado, por ejemplo, el que sujeta violentamente al guardavías e impide que éste cambie las vías del tren. En cambio, en la mera no evitación del resultado, el sujeto simplemente omite cambiar las vías del tren. El procedimiento para la verificación de la causalidad es parcialmente el mismo, con la diferencia solamente que en el segundo grupo de casos debe agregarse una acción determinada que el sujeto podía realizar y preguntarse si ésta hubiese evitado el resultado ${ }^{73}$. Sin embargo, Traeger observa una diferencia básica, derivada de la circunstancia que en el primer grupo de casos el sujeto realiza una actividad positiva que favorece el resultado. En cambio, en el segundo el sujeto no actúa. Advierte que induce a confusión decir que éste pone una condición negativa:

"El sujeto que omite no coloca ninguna condición del resultado. Su no acción se presenta meramente en un sentido lógico como una condición negativa del resultado, en tanto puede decirse respecto de aquel que permanece inactivo que si hubiese intervenido en una dirección determinada el resultado no se habría realizado"74.

Respecto del nexo causal, Traeger exige adicionalmente el requisito de la adecuación, del mismo modo que en el delito de acción. En este sentido, la omisión sería adecuada, si la acción representada como posible para el sujeto hubiese disminuido en una medida considerable la posibilidad objetiva del resultado -generalmente- de la clase del efectivamente realizado. La verificación de este requisito adicional se traduce en la pregunta por el nexo de causalidad adecuada entre el complejo de condiciones real y fácticamente presente en el momento de la acción a realizar y el resultado ${ }^{75}$.

\footnotetext{
${ }^{70}$ BINDING, Die Normen, t. II, $1^{\text {a }}$ parte, cit. nota n ${ }^{\circ}$ 65, p. 533.

${ }^{71}$ BINDING, Die Normen, t. II, $1^{\text {a }}$ parte, cit. nota n ${ }^{\circ} 65$, p. 561.

${ }^{72}$ MERKEL, Paul, Begehung durch Unterlassung, cit. nota $\mathrm{n}^{\mathrm{o}}$ 6, p. 30.

${ }^{73}$ TRAEGER, "Das Problem”, cit. nota no 64, p. 15 y s.

74 TRAEGER, “Das Problem”, cit. nota n ${ }^{\circ}$ 64, p. 17.

75 TRAEGER, “Das Problem”, cit. nota n 64, p. 24.
} 
ROJAS, Luis. "Delitos de omisión entre libertad y solidaridad".

La causalidad así comprendida es solamente uno de los requisitos para la punición de la omisión a título de comisión. Tanto Paul Merkel como Traeger, en el mismo sentido que la jurisprudencia del Reichsgericht, exigen adicionalmente la existencia de un deber jurídico y su infracción ${ }^{76}$.

El punto de partida es la estricta diferenciación del deber moral. Al igual que las prohibiciones, los mandatos deben emanar del Derecho. Un deber jurídico es exclusivamente aquel que emana de una fuente jurídica, cualquiera que ésta sea ${ }^{77}$. No obstante, Traeger reconoce de inmediato que existen leyes penales que establecen deberes de evitación frente a una situación de peligro, por ejemplo, el § 139 StGB sobre omisión de denuncia, el § 360 N. 10 sobre omisión de socorro previo requerimiento de la autoridad pública o el $\S 22$ párrafo 2 de la ley sobre vehículos motorizados ${ }^{78}$. En estos casos, es menester atender al fundamento de la norma respectiva, en términos tales que si el deber jurídico aparece como uno meramente de ayuda necesaria, esto es, un deber general de auxilio que rige en una situación de peligro con la cual el sujeto se encuentra confrontado casualmente, entonces su incumplimiento sólo debe sancionarse con la pena expresamente prevista por el legislador al efecto.

De este modo, enuncia el siguiente principio general: la no evitación del resultado equivale a su causación antijurídica allí donde existe un deber jurídico especial de evitación, cualquiera que sea la fuente jurídica del mismo. "Un deber general de auxilio impuesto por la ley como tal no es suficiente"79. Fuera de los casos antes mencionados, la ley sirve como fuente de tal deber especial, primero, cuando una ley penal tipifica expresamente un "delito impropio de omisión", como ocurre frecuentemente entre los delitos funcionarios. Segundo, tal deber puede surgir de una ley procesal o sustantiva, y en el ámbito de esta última, puede tratarse de una ley perteneciente al Derecho público o privado, como ocurre, por ejemplo, con el deber de manutención de los padres en relación a sus hijos, establecido en el Código civil $^{80}$.

Otra fuente jurídica del deber de evitación es el contrato. Al respecto, ya Paul Merkel aclara que no se trata de convertir al contrato mismo en fundamento jurídico de la pena. El fundamento es la lesión del bien jurídico amenazada con una pena, no el incumplimiento del contrato: "La relación contractual genera el deber jurídico de acción y éste constituye el fundamento de la antijuridicidad de la conducta del sujeto que omite" $"$.

Por su parte, Traeger se refiere a los "deberes asumidos mediante contrato" y sostiene expresamente que "la seguridad del individuo y de la sociedad se vería seriamente amenazada" si, en estos casos, el incumplimiento de deberes contractuales tuviese como

\footnotetext{
${ }^{76}$ MERKEL, Paul, Begehung durch Unterlassung, cit. nota n ${ }^{\circ}$ 6, pp. 31 y ss.; TRAEGER, “Das Problem”, cit. nota $\mathrm{n}^{\circ} 64$, pp. 26 y ss., 61 y ss.

77 TRAEGER, "Das Problem", cit. nota n ${ }^{\circ}$ 64, pp. 66 y ss., 80 y s.

${ }^{78}$ TRAEGER, "Das Problem", cit. nota n ${ }^{\circ}$ 64, pp. 72 y ss.

${ }^{79}$ TRAEGER, "Das Problem", cit. nota n ${ }^{\circ}$ 64, p. 77.

${ }^{80}$ MERKEL, Paul, Begehung durch Unterlassung, cit. nota nº 6, p. 32; TRAEGER, "Das Problem", cit. nota $\mathrm{n}^{\mathrm{o}} 64, \mathrm{p} .79$ y s.

${ }^{81}$ MERKEL, Paul, Begehung durch Unterlassung, cit. nota n ${ }^{\circ}$ 6, p. 33.
} 
consecuencia únicamente la indemnización de perjuicios. No obstante, al comentar luego la jurisprudencia del Reichsgericht aclara que, junto a tal incumplimiento, se requiere un resultado antijurídico que podría haber sido evitado por el sujeto ${ }^{82}$.

En relación a una variante del caso del nadador, rechaza la tesis que exige para la aplicación de esta figura que la asunción del deber conduzca a la posterior víctima a exponerse al peligro o implique apartar a terceros de intervenir en su ayuda. El rechazo precedente implicaría una cierta consecuencia severa en el caso del caminante que se encuentra en lugar despoblado con otro que ha sufrido un accidente y al cual le promete enviarle ayuda, pero luego por el largo camino que deber seguir, omite el aviso bajo la esperanza de que otros encuentren y ayuden a la víctima. Traeger advierte que sería contrario al sentimiento jurídico castigar al paseante con la misma pena del causante de la muerte. No obstante, en tal caso la promesa de enviar ayuda no sería más que un compromiso no vinculante y, por ende, no habría asunción de un deber jurídico. En los casos, empero, en que la promesa sí funda un encargo jurídicamente vinculante o un contrato de servicios, se trataría de deberes jurídicos de menor intensidad, cuya infracción ameritaría un marco penal rebajado y, en el evento de que la legislación no lo contemple, rebajar la pena a su piso mínimo ${ }^{83}$.

En cuanto a las características del deber jurídico surgido de un contrato, señala que no es necesario que tenga como objeto específico la evitación del resultado, por lo que basta una obligación genérica, por ejemplo, el vigilante nocturno cuyo contrato se refiere genéricamente a varios objetos y prestaciones, también tiene el deber de intervenir frente a un incendio. Y, según Traeger, tampoco es requisito que exista una conexión entre el contenido del deber jurídico asumido y la clase de resultados antijurídicos efectivamente realizados en el caso concreto ${ }^{84}$.

Finalmente, y al abordar ya las constelaciones de injerencia, menciona el caso del médico que, en el contexto de un accidente de trenes, comienza a operar a una víctima inconsciente y luego no concluye la intervención. Señala que ese caso no resulta problemático, pues existe una orden especial emanada del Derecho. Se trata de los preceptos del Código civil sobre agencia oficiosa ("Geschäftsführung ohne Auftrag"), por lo que el médico tiene en tal caso la obligación de concluir la operación o procurar que otro la termine ${ }^{85}$.

De este modo, la teoría del deber jurídico, al menos en esta formulación, deslinda ese último caso de las constelaciones de injerencia. Puesto que en el último ejemplo del médico, la acción previa del sujeto se dirige a la evitación del resultado. En cambio, es común a los casos de injerencia que la acción previa del sujeto causa la situación de peligro, que luego amenaza realizarse en perjuicio de la víctima.

Al interior de las constelaciones de injerencia, a su vez, se distinguen los casos en que el sujeto causa imprudentemente la situación de peligro, por ejemplo, el conductor del

\footnotetext{
82 TRAEGER, "Das Problem”, cit. nota no 64, p. 83 y s.

83 TRAEGER, “Das Problem”, cit. nota n ${ }^{\circ} 64$, p. 87.

${ }^{84}$ TRAEGER, "Das Problem”, cit. nota ${ }^{\circ}$ 64, pp. 87 y ss., p. 93; cfr. infra 5.3.

85 TRAEGER, "Das Problem”, cit. nota no 64, p. 95 y s.
} 
ROJAS, Luis. "Delitos de omisión entre libertad y solidaridad".

vehículo que atropella por imprudencia a una persona en una carretera rural y luego la abandona en una fría noche de invierno, por un lado, y aquellos en los cuales el sujeto causa "sin culpabilidad" la situación de peligro, el mismo ejemplo pero sin imprudencia, por el otro.

El primer grupo de casos de injerencia no es considerado problemático. Así, Traeger sostiene que en tal caso existe una orden especial del Derecho, emanada del § 249 BGB, norma que impone, al sujeto obligado a la indemnización de perjuicios, el deber de reestablecer el estado que existiría de no haberse realizado la circunstancia que obliga al resarcimiento. De ahí se deriva que la causación "culpable" de un resultado antijurídico obliga al sujeto a reestablecer el estado previo, también, y sobre todo, a la evitación de consecuencias más perniciosas que pueden desarrollarse a partir del estado provocado "culpablemente", supuesto que la víctima no puede ella misma evitar tales consecuencias.

Es el segundo grupo de casos de injerencia el que resulta discutido. En tales constelaciones, Traeger, si bien parte de la existencia de un deber jurídico de evitación y, por ende, se refiere a una omisión "culpable", considera justificado introducir una excepción a la regla de equivalencia antes formulada, porque, en ese caso, tal omisión "culpable" no puede valorarse en los términos de una equivalencia completa con la causación "culpable"

Sin embargo, la pregunta previa que esta teoría debe responder atañe al fundamento u origen del deber jurídico de evitación también en esos casos de injerencia. Sobre el punto, Paul Merkel sostiene que cada uno debe, en todo momento, organizar su propia actividad de tal manera que la esfera de bienes jurídicos de terceros no se vea lesionada. El sujeto debe, también cuando realiza una acción permitida por el ordenamiento jurídico de la cual surge la amenaza de lesión a la esfera de bienes jurídicos de terceros, tratar de evitar tal lesión mediante la actividad correspondiente, de tal modo que si no realiza la acción impeditiva, su conducta es antijurídica ${ }^{87}$.

En este sentido, Traeger califica la premisa enunciada del deber de organización del ciudadano como una emanada del Derecho consuetudinario ${ }^{88}$. En estos casos, la acción previa del sujeto genera un estado objetivamente antijurídico de peligro y aquél tiene el deber jurídico de evitar las consecuencias dañosas que pueden derivar de dicho estado, "en la medida en que se le pueda exigir razonablemente". Incluso existe tal deber en el caso del sujeto que ejerciendo legítimamente la defensa necesaria lesiona al agresor, lo deja sin ayuda y corre este último el riesgo de morir. Aclara finalmente que en estos casos no se trata de un deber fundado en la pura casualidad, como es característico del deber general de auxilio, sino que existe una relación especial entre el obligado a la evitación y el estado de peligro presente. Aquí no vale el juicio de que el resultado dañoso igualmente hubiese ocurrido si el sujeto que omite no hubiese existido, sino que rige precisamente lo inverso, esto es, si el sujeto no

\footnotetext{
${ }^{86}$ TRAEGER, "Das Problem", cit. nota no 64, p. 71.

${ }^{87}$ MERKEL, Paul, Begehung durch Unterlassung, cit. nota $n^{\circ}$ 6, p. 36.

${ }^{88}$ Cfr. TRAEGER, "Das Problem”, cit. nota n ${ }^{\circ}$ 64, p. 104.
} 
Polít. crim. Vol. 13, No 26 (Diciembre 2018) Art. 2, pp. 682-783.

[http://www.politicacriminal.cl/Vol_13/n_26/Vol13N26A2.pdf]

hubiese provocado el estado de peligro mediante su hacer, el resultado dañoso no se habría producido ${ }^{89}$.

\subsection{Conclusión intermedia: el contexto de surgimiento de la posición de garante}

Los planteamientos latamente descritos muestran el estado de la discusión entre doctrina y jurisprudencia previo al desarrollo del concepto de posición de garante. Es en este contexto espiritual donde tiene lugar la inflexión que lleva a concebir la posición de garante, entendida en el sentido actual de la expresión. Como se puede ver, se trata de un contexto dividido, donde la cuestión de la causalidad de la omisión juega un rol preponderante.

Simplificando bastante, si se parte de la premisa de su negación, la causalidad igualmente se busca y luego se encuentra en la acción previa del sujeto, con el consecuente desprecio por la existencia formal del deber jurídico -hasta negarle toda relevancia o darle un status subordinado. La cuestión de la equivalencia con el delito comisivo se resuelve por la vía de compensar la ausencia de causalidad en la omisión mediante la presencia de aquella en la acción previa. De este modo, la pregunta por la existencia formal de un deber jurídico se torna superflua. Puesto que la causalidad de la acción previa, en definitiva, implica que el daño deriva de ésta -vulnerando ya así el "neaminem laedere"- y, por ende, la infracción del deber jurídico no juega ningún rol constitutivo.

$\mathrm{Si}$, en cambio, se afirma la causalidad de la omisión, al menos en un sentido lógico, entonces la cuestión del deber fundado jurídicamente recobra importancia como elemento adicional. Esto porque la comprobación de la causalidad en la omisión es menos evidente que en el delito de acción. Es más dependiente de un juicio de probabilidad acerca de lo que habría ocurrido en el evento de que el sujeto hubiese realizado la acción impeditiva. Pero, la formulación de este juicio de probabilidad presupone la existencia de un deber de realizar la acción impeditiva, cuestión que no es necesaria para emitir tal juicio en la comprobación de la causalidad de la acción. De ahí que la equivalencia entre omisión y comisión es aquí dependiente de los pasos sucesivos de la comprobación de la causalidad y luego de la existencia formal del deber jurídico -y su incumplimiento.

Pues bien, es en este contexto histórico donde se acuña el concepto de posición de garante. $\mathrm{Su}$ nacimiento responde a la necesidad de hacer depender la cuestión de la equivalencia entre comisión y omisión de criterios materiales y no meramente formales. En otras palabras, dicha equivalencia no puede depender de la sola existencia formal de un deber jurídico y su incumplimiento.

Sin embargo, y a pesar de que pueden encontrarse algunas voces en ese sentido, conforme a la teoría del deber jurídico dicha equivalencia nunca dependió solamente de tal infracción del deber, sino que siempre se exigió para ello adicionalmente el nexo de causalidad, aun cuando éste fuera comprendido en un sentido débil o se fundara meramente en un juicio de probabilidad. Y, otra vez, es el cuestionamiento de la existencia de este nexo el que gatilla

\footnotetext{
${ }^{89}$ TRAEGER, "Das Problem", cit. nota nº 64, p. 106 y s.; cabe señalar que, a su vez, el mismo, TRAEGER, "Das Problem", cit. nota n 64, p. 108 y s., diferencia de estos casos aquellos en los cuales el estado de peligro se genera al interior del ámbito de dominio del sujeto.
} 
ROJAS, Luis. "Delitos de omisión entre libertad y solidaridad".

la errónea creencia del postulado de equivalencia por la sola infracción del deber jurídico. Pero, visto atentamente, es la crítica a la teoría del deber jurídico, no esta misma, la que sostiene la ausencia de causalidad en la omisión. Este supuesto errado de la crítica explica que se le achaque a la teoría del deber jurídico la pretensión de colmar el supuesto vacío con la infracción del deber. Este malentendido explica en buena medida el origen y desarrollo ulterior del concepto de posición de garante.

\section{Formulación originaria del principio de garantía}

En efecto, el nacimiento del concepto de posición de garante, en el sentido contemporáneo de la expresión, puede situarse temporalmente en la década del 30 del siglo pasado. Es el producto de la obra de diversos autores, que confluyen todos en situar la posición de garante como un elemento del tipo de la omisión impropia.

En ese contexto, sobresale la obra de tres autores que no se citaron entre sí, quizás por desconocimiento, en un caso, y por publicación parcialmente extemporánea, en el otro. Mas el azar histórico del desencuentro no es óbice a la convergencia teórica. Se trata de la tesis doctoral de Ulrich Mayer (1934), del famoso artículo de Nagler (1938) y de la tesis de habilitación de Gallas (1932 $)^{90}$. Los tres autores reconocen explícitamente la influencia de la filosofía de los valores de orientación neokantiana ${ }^{91}$. Asimismo, parten de una crítica a la teoría del tipo sostenida en la época por Beling, premisa que les autoriza a comprender esta categoría como un "tipo de injusto"92.

Pues bien, sobre estas bases filosóficas y teóricas se acuña el concepto de posición de garante como elemento del tipo. Esta ubicación sistemática es común a los tres planteamientos, que luego divergen parcialmente en la explicación del fundamento material de la posición de garante. A nivel de fundamentación, y adoptando un criterio ligeramente arbitrario, puede distinguirse una tesis liberal -U. Mayer-, una explícitamente antiliberal -Nagler-y una síntesis -Gallas.

\footnotetext{
${ }^{90}$ MAYER, Ulrich, Die besonderen Tatbestandsmerkmale der unechten Unterlassungsdelikte, Heidelberg: sin editorial, 1934; NAGLER, Johannes, "Die Problematik der Begehung durch Unterlassung", Der Gerichtssaal $(G S)$, t. 111 (1938), pp. 1 y ss.; GALLAS, Studien, cit. nota $\mathrm{n}^{\circ} 11$, que incluye "Das Wesen des strafrechtlichen Unterlassens und seine Stellung im System der Verbrechenslehre (1932)", pp. 1 y ss., y "Die Garantenpflicht des Unterlassungstäters (1963)", pp. 67 y ss.; asimismo, cabe mencionar a MEZGER, Edmund, Strafrecht, München/Leipzig: Duncker \& Humblot, 1931, pp. 130 y ss., y a DROST, "Der Aufbau der Unterlassungsdelikte", en $G S$, t. 109 (1937), pp. 1 y ss., sin embargo, el aporte conceptual de este último es muy precario.

${ }^{91}$ Cfr. GALLAS, Studien, cit. nota $\mathrm{n}^{\mathrm{o}} 11$, p. 51 y s. ("El substrato real del delito sólo puede consistir en un fragmento de la realidad social, esto es, referida a los valores comunitarios"); MAYER, Diss., cit. nota n $^{\circ}$ 90, p. 3 (disolución del pensamiento científico-natural ajeno a la jurisprudencia); NAGLER, "GS 1938", cit. nota $\mathrm{n}^{\circ} 90$, pp. 29 y ss.; cabe tener presente que este último trabajo contiene referencias explícitas al "pensamiento jurídico del nacionalsocialismo" (pp. 44 y ss., 84 y ss.) y una sugerente adenda sobre la "nueva ciencia jurídica" (pp. 122 y ss.), pasajes de los cuales se hace conscientemente abstracción, en tanto el resto del trabajo es dogmáticamente riguroso.

${ }^{92}$ Cfr. GALLAS, Studien, cit. nota ${ }^{\circ} 11$, p. 44 y s.; con detalle, MAYER, Diss., cit. nota $n^{\circ}$ 90, pp. 27 y ss.; NAGLER, "GS", cit. nota $\mathrm{n}{ }^{\circ}$ 90, p. 52 nota 97a.
} 
Polít. crim. Vol. 13, No 26 (Diciembre 2018) Art. 2, pp. 682-783.

[http://www.politicacriminal.cl/Vol_13/n_26/Vol13N26A2.pdf]

\subsection{La tesis liberal de Ulrich Mayer}

Según Ulrich Mayer, la cuestión de la equivalencia entre omisión y comisión pertenece sistemáticamente al tipo ${ }^{93}$. En el punto de partida, constata que la omisión sola "lógicamente" no puede causar el resultado y, por ende, es siempre dependiente de otras condiciones positivas que deben haber producido un peligro. Aquí el planteamiento recuerda al principio de la actividad previa y a la teoría de la interferencia. No obstante, Mayer critica estos planteamientos por disolver la pregunta fundamental en elementos puramente descriptivos, soslayando el significado normativo de éstos ${ }^{94}$. Partiendo de una comprensión del tipo como "lesión de intereses tipificada" y de la premisa que los intereses, a diferencia de las normas, admiten ponderación, señala que los presupuestos especiales de punibilidad de la omisión impropia pertenecen ya al tipo como elementos no escritos ${ }^{95}$.

La punibilidad depende de la concurrencia de estos presupuestos, no de las fuentes de la ley ni del contrato. Así, y en relación a la ley, hace ver que existen tanto casos tomados de la jurisprudencia en los cuales se afirma el merecimiento penal en ausencia de ley como casos de falta de tal merecimiento a pesar de la presencia de leyes ${ }^{96}$. Lo anterior, a fin de sostener que lo decisivo es el "contenido de injusto" del hecho, el que, a diferencia de la "intensidad de una norma", puede "pesarse" y para lo cual se dispone de un parámetro comparativo en el hacer, de tal modo que la equivalencia de la omisión con éste se fija según dicho parámetro y quedan así excluidas aquellas omisiones que a la luz del mismo resultan ser desigua$\operatorname{les}^{97}$.

En cuanto al contrato, también muestra que existen tanto casos de merecimiento penal a pesar de la ausencia de deberes contractuales como de falta de merecimiento penal a pesar de la concurrencia de tales deberes, como en el ejemplo del guía de montaña que a tiempo, pero en incumplimiento del contrato, se niega a cumplir el cometido ${ }^{98}$. Luego de tratar la injerencia, reitera que lo decisivo es el "peso" del contenido de injusto en la situación concreta, según la relación del sujeto, por un lado, y el peligro o el bien jurídico en peligro, por el otro ${ }^{99}$.

De ese modo, Mayer aclara que el elemento no escrito del tipo es normativo, pero no en el sentido de una valoración extraída de otros ámbitos jurídicos ${ }^{100}$. Compara la situación causal en la acción y en la omisión, para constatar que en esta última la causalidad natural ya se encuentra en curso, por lo que se trata aquí, a diferencia que en la acción, del no impedimento de un peligro ya presente. El mandato de realizar tal acción impeditiva significa una

\footnotetext{
${ }^{93}$ MAYER, Diss., cit. nota $n^{\circ}$ 90, p. 5.

${ }^{94}$ MAYER, Diss., cit. nota n ${ }^{\circ} 90$, pp. 11 y s., 21 y s., 23.

${ }^{95}$ MAYER, Diss., cit. nota n ${ }^{\circ} 90$, pp. 38, 41 y s.

${ }^{96}$ MAYER, Diss., cit. nota ${ }^{\circ}$ 90, pp. 44 y ss.

${ }^{97}$ MAYER, Diss., cit. nota n ${ }^{\circ}$ 90, p. 38.

${ }^{98}$ MAYER, Diss., cit. nota ${ }^{\circ}$ 90, pp. 60 y ss.; respecto de este último ejemplo, así también MEZGER, Strafrecht, cit. nota ${ }^{\circ} 90$, p. 144, aunque con la circunstancia agregada de que el turista emprende la marcha "a riesgo propio".

${ }^{99}$ MAYER, Diss., cit. nota n ${ }^{\circ} 90$, pp. 68 y ss., p. 73 y s.

${ }^{100}$ MAYER, Diss., cit. nota n ${ }^{\circ}$ 90, p. 74.
} 
ROJAS, Luis. "Delitos de omisión entre libertad y solidaridad".

restricción comparativamente mayor a la "esfera personal de libertad" del sujeto ${ }^{101}$. Es necesaria, entonces, una ponderación del interés en el bien jurídico en peligro, por un lado, y del interés en la esfera intacta de libertad, por el otro, en términos tales que si el primero es preponderante y falta el segundo, puede afirmarse la equivalencia entre omisión y comisión $^{102}$. Para determinar la preponderancia del interés en el bien jurídico, en un lado de la balanza, sirve observar la relevancia fijada en el tipo de omisión de denuncia y en la todavía contravención de omisión de socorro ${ }^{103}$. La restricción de la libertad del sujeto, en el otro, se justifica en la medida en que exista fácticamente una relación de cercanía ("nahe Beziehung") ya sea con el peligro mismo o con el bien jurídico en peligro, que convierta al sujeto en garante.

Así, Mayer distingue dos clases de relaciones de cercanía o proximidad. La primera es la relación de cercanía con el peligro, que corresponde a la antigua categoría del hacer precedente y también del contrato. En estos casos, el sujeto ha causado mediante su hacer el peligro, i.e., su existencia es conditio sine qua non de éste. El mandato de acción significa aquí el deber de no hacer efectiva la propia conducta socialmente dañosa, por ende, su contenido no implica prestar utilidad a la sociedad ${ }^{104}$. La segunda es la relación de cercanía con el bien jurídico en peligro. En estos casos, el sujeto no necesariamente ha causado el peligro, por lo que se le exige no solamente que no dañe, sino que mediante su intervención preste utilidad a la sociedad. Se trata de deberes calificados que se fundan en una posición cualificada del obligado, la que, a su vez, deriva de la relación cercana de éste con el bien jurídico o con su portador. Aquí se menciona el caso del sujeto que cava una zanja y la usa, momento en el cual se coloca en una posición que lo convierte en garante de la integridad corporal de las personas que entran en contacto con su actividad ${ }^{105}$.

En estos casos, la categoría tradicional del contrato sirve solamente como un criterio orientador, mas su vigencia carece de importancia. En los casos dudosos, cabe atender a la circunstancia psicológica en la persona de la contraparte, en términos tales de detectar si ésta se ha confiado en el garante, i.e., si contando con su ayuda el bien jurídico se ha expuesto al peligro. Lo decisivo en tales casos radica en que los bienes jurídicos se han confiado al garante, quien fácticamente ha asumido su protección y se ha confiado en él ${ }^{106}$. El elemento del confiarse es suficiente, no es necesario verificar si otra ayuda era fácticamente posible. Así, en el caso sugerido por Binding del joven intrépido, cuya madre discretamente

${ }^{101}$ MAYER, Diss., cit. nota no 90, p. 76.

102 También atiende a una ponderación, aunque en clave más bien colectivista, KISSIN, Siegfried, Die Rechtspflicht zum Handeln bei den Unterlassungsdelikten, Breslau-Neukirch: Alfred Kurtze, 1933, pp. 98 y ss.

${ }^{103}$ MAYER, Diss., cit. nota ${ }^{\circ}$ 90, p. 78 y s.; recurre posteriormente al umbral de relevancia de los intereses jurídicos protegidos por estas normas como filtro para determinar el alcance eventualmente injusto de las así llamadas "conductas neutrales" FRISCH, Wolfgang, Tatbestandsmässiges Verhalten und Zurechnung des Erfolgs, Heidelberg: C.F. Müller, 2012, p. 313 y s.

${ }^{104}$ MAYER, Diss., cit. nota ${ }^{\circ}$ 90, p. 81; dicho en los términos de la discusión actual, no se trata de un deber positivo.

${ }^{105}$ MAYER, Diss., cit. nota no 90 , p. 82 y s.

${ }^{106}$ MAYER, Diss., cit. nota $\mathrm{n}^{\circ}$ 90, p. 85; cfr. MEZGER, Strafrecht, cit. nota $\mathrm{n}^{\circ}$ 90, p. 144: "hay responsabilidad penal, porque la contraparte se ha confiado en la ayuda comprometida y, bajo dicha confianza, ha omitido otras medidas de aseguramiento. Aquí el sujeto que se obliga se convierte en "garante". 
Polít. crim. Vol. 13, No 26 (Diciembre 2018) Art. 2, pp. 682-783.

[http://www.politicacriminal.cl/Vol_13/n_26/Vol13N26A2.pdf]

le encarga por 20 marcos a un pescador rescatar al hijo en el evento de un peligro, U. Mayer sostiene que, si bien no existe una relación de cercanía con el peligro, sí puede hablarse de una tal relación con el bien jurídico, pues la madre se ha confiado en el pescador ${ }^{107}$.

\subsection{Resumen}

En síntesis, U. Mayer identifica el "contenido de injusto" del hecho como parámetro comparativo entre hacer y omitir para la formulación del juicio de equivalencia ${ }^{108}$. La perspectiva adoptada es explícitamente normativa. De hecho, y como parte de la premisa que un mandato de acción implica una restricción comparativamente mayor de la libertad personal del sujeto, hace ver la necesidad de formular un juicio de ponderación entre el interés en la protección del bien jurídico, por un lado, y el interés en la esfera personal de libertad, por el otro ${ }^{109}$. Determinado previamente el interés de protección, la restricción de la libertad del sujeto se justifica en la medida en que exista una relación de cercanía de éste con el peligro o con el bien jurídico protegido, esto es, en tanto el sujeto se encuentre en una posición de garante.

Distingue así entre relaciones de garante vinculadas con el peligro mismo, por una parte, y con el bien jurídico o su portador, por otra ${ }^{110}$. Pero no solamente eso. También vincula la primera clase de relaciones de garante con el mandato general de neutralizar el carácter dañoso de la propia conducta, al mismo tiempo que desliga su alcance de la idea de prestar utilidad a la sociedad. En clave moderna, subyacen a tal clase de relaciones deberes negativos. Mientras que en la segunda clase de relaciones de garante se trata de deberes calificados, cuyo contenido no se agota en tal mandato de neutralización, sino que incluye prestar un beneficio a la sociedad ${ }^{111}$. En cuanto a este segundo grupo de relaciones de garantía, cabe tener presente que U. Mayer le asigna relevancia, en los casos dudosos, a la circunstancia que el portador del bien jurídico confíe en el sujeto y, contando con su ayuda, se exponga al peligro. Esta circunstancia es relevante para fundar la posición de garante en tales casos, como en el ejemplo del nadador intrépido.

\subsection{La concepción antiliberal de Nagler}

Metodológicamente, el planteamiento de Nagler se inserta en el proceso de emancipación de una concepción privatista, proceso que habría comenzado ya a mitad del siglo XIX y que

\footnotetext{
${ }^{107}$ MAYER, Diss., cit. nota no 90, p. 85 y s.

${ }^{108}$ En este punto, la tesis de U. Mayer es coetánea a la de Gallas, vid. infra 4.5.

${ }^{109}$ De este modo, instala un precedente al planteamiento desarrollado posteriormente por FREUND, Georg, Erfolgsdelikt und Unterlassen, Köln: Heymanns, 1992, pp. 51 y ss., sobre los criterios de determinación de la conducta típica en base a los dos pilares del "dato de la utilidad del seguimiento de la norma", por un lado, y de la "responsabilidad especial" por el curso dañoso a evitar, por el otro.

${ }^{110}$ De esta manera, se adelanta a la "teoría de las funciones" popularizada un par de décadas después por KAUFMANN, Dogmatik der Unterlassungsdelikte, cit. nota $\mathrm{n}^{\circ}$ 17, pp. 282 y ss., vid. infra nota 158.

${ }^{111}$ De este modo, se adelanta a la vinculación entre posiciones de garante de vigilancia y deberes negativos, de un lado, y posiciones de garante de protección y deberes positivos, por el otro, desarrollada posteriormente por JAKOBS, Die strafrechtliche Zurechnung, cit. nota $\mathrm{n}^{\mathrm{o}} 13$, pp. 19 y ss., 30 y ss.
} 
ROJAS, Luis. "Delitos de omisión entre libertad y solidaridad".

permite captar las características jurídico-públicas del Derecho penal ${ }^{112}$. En la discusión sobre la causalidad de la omisión, dicha perspectiva jurídica obligaría a avanzar desde el interior de la causalidad al contenido de sentido del acontecimiento. Sostiene que la ciencia jurídico-penal ha madurado para captar autónomamente la causación, pudiendo ahora comprender jurídicamente la pregunta causal en concordancia con la "visión común natural". Lo decisivo sería la determinación final. El no impedimento de un resultado antijurídico amenazante, que habría sido evitado según la previsibilidad humana mediante una intervención oportuna, puede adquirir, en el contexto social y así en la realidad de la vida comunitaria, el significado determinante en la realización del daño jurídico. Lo decisivo sería una valoración social-jurídica del acontecimiento. Desde una perspectiva que observa la realidad práctica, los elementos funcionales destacan en un primer plano. Por lo que resultaría completamente superfluo ver una dificultad en la circunstancia de que a la omisión, en tanto algo puramente negativo, no puede atribuírsele ninguna eficacia ${ }^{113}$.

Luego de describir el proceso de avance desde conceptos jurídicos entendidos formalmente a su comprensión material, Nagler arriba a la conclusión de que la ley en el sentido del liberalismo se ha apartado del Derecho material obtenido directamente de la consciencia popular y de la fuente originaria de la "esencia germana". Conformidad y contrariedad a Derecho se determinarían ahora según el "sano sentimiento popular". Tras el abandono de la fórmula de Feuerbach, no existe más coerción al formalismo legal y se ha regresado a la fase jurídica previa a la época liberal ${ }^{114}$.

Según Nagler, la solución del problema de la "comisión por omisión" se ubica en el tipo, concretamente, en sede de acción típica. La pregunta por la equivalencia se responde según la voluntad de la ley. Lo anterior quedaría en evidencia cuando el propio Código penal equipara expresamente la comisión con la omisión en el ámbito de la acción descrita por el tipo, como ocurre, por ejemplo, en el tipo del delito de abandono $-\S 221 \mathrm{StGB}$. Por otro lado, precisamente por exigencias de la tipicidad existen varios delitos comisivos que no pueden realizarse mediante omisión, como por ejemplo, los delitos de propia mano ${ }^{115}$. Los tipos que equiparan la acción con la omisión, como ocurre frecuentemente entre los delitos funcionarios, caracterizan especialmente al sujeto activo, esto es, como garante por la no realización del resultado. La ley hace depender la equivalencia entre comisión y omisión de una relación especial de deberes. En estos casos, la prohibición contiene la no evitación ${ }^{116}$. En la medida en que un miembro de la comunidad se encuentra jurídicamente encargado de tareas de protección, el mandato contenido en la prohibición extiende la acción típica a la omisión del impedimento del resultado antijurídico. Este mandato, empero, nunca rige de modo general, sino que siempre especial, pues se encuentra dirigido al garante, quien adquiere en la vida jurídica una posición especial a consecuencia de la obligación a cumplir tareas de protección ${ }^{117}$. Respecto de él, el tipo se realiza con signo inverso, esto es, contraviene la prohibición tanto mediante una acción positiva como por pasividad. De ahí enton-

\footnotetext{
112 NAGLER, “GS 1938”, cit. nota n 90, pp. 23 y ss.

113 NAGLER, “GS 1938”, cit. nota no 90, p. 33 y s.

114 NAGLER, “GS 1938”, cit. nota nº 90, p. 40.

115 NAGLER, “GS 1938”, cit. nota no 90, pp. 51 y ss.

116 NAGLER, “GS 1938”, cit. nota no 90, p. 59 y s.

${ }^{117}$ KISSIN, Die Rechtspflicht, cit. nota ${ }^{\circ}$ 102, pp. 107 y ss., se refiere a la posición jurídico-social del autor.
} 
Polít. crim. Vol. 13, No 26 (Diciembre 2018) Art. 2, pp. 682-783.

[http://www.politicacriminal.cl/Vol_13/n_26/Vol13N26A2.pdf]

ces que la equivalencia entre actividad y pasividad derivaría no tanto de una ampliación del tipo, sino que más bien de una corrección del mismo en virtud de una interpretación del texto extensiva orientada al fin ${ }^{118}$.

Esa posición jurídica especial puede surgir de varios modos, mas lo decisivo sería el llamado directo del ordenamiento jurídico mismo. La ley sirve aquí usualmente de orientación, pero no es imprescindible. La comunidad jurídica puede relacionar el deber jurídico con determinados acontecimientos de la vida social, como una acción previa en los casos de la injerencia o la asunción contractual de determinadas funciones de protección. Pero, en este segundo caso, el contrato sólo produce la posición social de defensa, a la cual el ordenamiento jurídico le impone el deber jurídico-público de protección ${ }^{119}$. En cuanto a la extensión temporal y alcance de la posición jurídica especial, en el evento de dudas, se determinaría caso a caso. No en última instancia debe observarse la proporcionalidad entre el sacrificio exigido al garante y el daño a evitar ${ }^{120}$.

Sostiene Nagler que existe certeza de la exclusión del ámbito de la omisión impropia solamente en los casos en que la ley ha establecido mandatos de actividad, cuyo incumplimiento da lugar a un delito omisivo, como la omisión de socorro y de denuncia, a menos que la obligación de garantía surja de otro fundamento como la injerencia. También quedarían excluidas las obligaciones de intervención establecidas en otros ámbitos del Derecho, como el Derecho administrativo, y los meros deberes de auxilio ${ }^{121}$. El efecto psicológico en otros de la posición de garante sería irrelevante. Asimismo, la confianza de la comunidad jurídica en el funcionamiento de la instancia de defensa es prescindible en el caso concreto $^{122}$.

Existiendo la equivalencia reseñada con la acción, la estructura del delito de omisión impropia sería la misma que el delito de acción ${ }^{123}$. Esto implica que la responsabilidad plena exige la realización del resultado. Aquí la pregunta por la causalidad se plantearía en los mismos términos. Abandonada una teoría natural de la causalidad y siguiendo un concepto jurídico-penal de la misma, ésta se daría por establecida al fracasar la posición de protección y dejar que ocurran las fuerzas productivas del resultado. Esta verificación exige una observación eventual, un juicio hipotético, que se fundaría en una "probabilidad jurídica" incrementada ${ }^{124}$. Adicionalmente, debería verificarse la antijuridicidad y la culpabilidad. Sin embargo, y dado que el deber jurídico que surge de la posición de garante ya se comprueba en el tipo, no debería volver a considerarse en sede de antijuridicidad, para lo cual basta verificar la eventual concurrencia de causas de exclusión del injusto ${ }^{125}$.

\footnotetext{
118 NAGLER, ,GS 1938“, cit. nota n 90, p. 61.

119 NAGLER, „GS 1938“, cit. nota nº 90, p. 62 y s.

${ }^{120}$ NAGLER, ,GS 1938“, cit. nota n 90, p. 64.

${ }^{121}$ NAGLER, "GS 1938”, cit. nota no 90, pp. 65 y ss.

122 NAGLER, “GS 1938”, cit. nota n 90, p. 68.

${ }^{123}$ Es lo que va a ser negado decididamente un par de décadas después por KAUFMANN, Dogmatik, vid. infra nota 158 .

${ }^{124}$ NAGLER, “GS 1938”, cit. nota n 00 , pp. 69 y ss.

${ }^{125}$ NAGLER, “GS 1938”, cit. nota no 90, p. 74 y s.
} 
ROJAS, Luis. "Delitos de omisión entre libertad y solidaridad".

\subsection{Resumen}

En síntesis, también la concepción de Nagler es explícitamente normativa, sin embargo, parece ubicarse en las antípodas de la tesis de U. Mayer. La posición de garante consiste en una relación especial de deberes de carácter jurídico-público, emanada directamente del ordenamiento jurídico. Es Nagler quien instala definitivamente la concepción hoy aceptada generalmente de que dicha posición de garante es un elemento no escrito del tipo comisivo, que surge de una interpretación extensiva del mismo, orientada teleológicamente. El reconocimiento de este elemento implica que la prohibición contiene el mandato de acción, de tal modo que el sujeto así obligado la contraviene tanto mediante acción como por omisión. No le asigna relevancia a la confianza como elemento fundante de la posición de garante. Finalmente, llama la atención el abandono explícito de un concepto "natural" de causalidad en la omisión y su reemplazo por una concepción "jurídico-penal" de la misma, que supone un juicio hipotético de "probabilidad jurídica". Lo determinante sería el fracaso de la instancia de defensa, que deja suceder las fuerzas productivas del resultado.

\subsection{La síntesis de Gallas}

Luego de un extenso análisis de la tesis sobre omisión de Gerhart Husserl, concluye Gallas que omisión es la no realización de un hacer ordenado por una norma de deber ${ }^{126}$. Sistemáticamente, ella participaría necesariamente de la tipicidad ${ }^{127}$. Por su parte, el precepto de deber es una categoría valorativa autónoma y puede formularse tanto en términos positivos como negativos. En el delito omisivo, dicho precepto de deber es positivo y el injusto surge de la comparación de sentido con la ausencia de la conducta hipotética esperada. Adicionalmente, debe observarse el círculo de problemas que se discute bajo el acápite de la imputación como principio limitativo de la causalidad -teorías de la adecuación. Los presupuestos de la imputación se orientan al fin y sentido de la ley penal y, por ende, deben tematizarse en la teoría del tipo como parte de la teoría del injusto. Finalmente, debería observarse la exigencia de culpabilidad ${ }^{128}$.

Esas consideraciones las formula Gallas en 1932, en general, respecto del delito de omisión. Treinta años después aborda al deber de garante del autor de omisión.

Frente a la jurisprudencia ahora del Tribunal supremo federal $(\mathrm{BGH})^{129}$, que tiende a traspasar el límite del Derecho con la moral, Gallas cree ver en la posición de garante un progreso solamente si se entiende como un criterio práctico-objetivo de los presupuestos bajo los cuales la no evitación de un resultado típico puede considerarse equivalente a su producción mediante hacer positivo. Ya que en los casos de omisión no puede acudirse directamente a la acción descrita en el tipo, el parámetro para la tipicidad de la no evitación

\footnotetext{
${ }^{126}$ GALLAS, Studien, cit. nota n ${ }^{\circ} 11$, p. 28 y s.

${ }^{127}$ GALLAS, Studien, cit. nota n ${ }^{\circ} 11$, p. 51 ("Typizität").

${ }^{128}$ GALLAS, Studien, cit. nota $\mathrm{n}^{\circ} 11$, pp. 62 y ss.

${ }^{129}$ A título ejemplar, BGHSt. 2, 12.02.1952, pp. 150 y ss.
} 
Polít. crim. Vol. 13, No 26 (Diciembre 2018) Art. 2, pp. 682-783.

[http://www.politicacriminal.cl/Vol_13/n_26/Vol13N26A2.pdf]

del resultado sólo puede encontrarse en el contenido de injusto material del tipo comisivo $^{130}$.

Sin embargo, Gallas advierte que ese parámetro entrega una cláusula de equivalencia todavía abierta, que es colmada por la doctrina y jurisprudencia mediante los presupuestos del deber jurídico a la acción, de la exigencia de que tal deber ha de dirigirse a la evitación del resultado $\mathrm{y}$, finalmente, de la "autoría potencial" del sujeto, esto es, que haya podido efectivamente intervenir y que, en tal evento, el resultado se habría evitado con una probabilidad rayana en la certeza. Satisfacerse con estos tres requisitos sería problemático, pues implicaría no colocar mayores exigencias al deber jurídico, de tal manera que la infracción a cualquier deber extraído de alguna parcela del ordenamiento jurídico fundaría la responsabilidad penal del sujeto por el resultado típico. Esa concepción se justificaría aún en una época en la cual se partía de la causalidad de la omisión y a la cual se agregaba la exigencia del deber jurídico que, en esa medida, cumplía una función limitadora de la punibilidad. Pero, sería incorrecta desde el momento en que ya no se ve en la causación del resultado el tertium comparationis para la equivalencia, sino que en el contenido de injusto material descrito en el tipo comisivo ${ }^{131}$.

Tras el abandono del dogma de la causalidad de la omisión, la no evitación del resultado típico como tal sería jurídico-penalmente irrelevante. Y, por ejemplo, un mero incumplimiento contractual no puede tener la fuerza de convertir una conducta jurídico-penalmente irrelevante en una punible. Además de los señalados presupuestos, sería menester un criterio restrictivo adicional, esto es, una cualificación del deber de evitación del resultado. Esta concurriría cuando el deber infringido se funda en una relación especial del obligado con el bien jurídico protegido. Gallas cree encontrar ese criterio restrictivo en la posición de garante ${ }^{132}$.

Para ejemplificar su aplicación, Gallas propone el siguiente caso de cátedra. En una tarde de verano, la administración de un balneario organiza una carrera de natación en el lago. Por 20 marcos, aquélla ha comprometido a X, cuestión sabida por los participantes, a fin de que los acompañe con su bote a motor y los auxilie en caso de ser necesario. Conforme a lo acordado, $\mathrm{X}$ conduce el bote por un rato cerca de los nadadores hasta que, en el medio del lago, presta oído a la sugerencia de su novia, que lo había acompañado, para luego abandonar a los nadadores y partir a dar un paseo. Uno de los nadadores pierde sus fuerzas y se ahoga. Éste se habría salvado si X hubiese cumplido su promesa.

Si se atiende al deber jurídico, éste ya surge en el momento de celebración del contrato, de modo que en la variante (2.) del caso en la cual X, observado por todos los participantes, no aparece en el momento acordado y la competencia se realiza igual, ahogándose uno de los participantes, $\mathrm{X}$ habría infringido su deber contractual, cuyo cumplimiento eventual habría evitado la muerte del nadador. Y en otra variante (3.), en la cual X es menor de edad, por lo que el contrato celebrado es nulo por falta de aprobación de los padres, el contrato cele-

\footnotetext{
${ }^{130}$ GALLAS, Studien, cit. nota ${ }^{\circ} 11$, p. 74 y s.

${ }^{131}$ GALLAS, Studien, cit. nota $\mathrm{n}^{\circ} 11$, p. 75 y s.

${ }^{132}$ GALLAS, Studien, cit. nota ${ }^{\circ} 11$, p. 76 y s.
} 
ROJAS, Luis. "Delitos de omisión entre libertad y solidaridad".

brado dejaría de tener el significado atribuido a primera vista. Lo decisivo sería la asunción fáctica de una función de protección, criterio conforme al cual en la versión original y en la segunda variante (3.), mas no en la primera (2.), resultaría punible ${ }^{133}$. Ello sería así porque en esos dos casos el nadador se ha colocado en la situación de peligro por la confianza depositada en la función de protección asumida por X.

Efectivamente, el que se comporta de tal manera que mediante la asunción de la función de protección coloca a la víctima en situación de peligro y así se convierte en "señor de su destino", obraría tan peligrosamente como aquel que contribuye mediante hacer a la muerte de la víctima. Este punto de vista plantea empero el dilema consistente en que, al prescindir del contrato como fundamento jurídico, se fundaría o en un deber moral o en la "fuerza normativa de lo fáctico". No quedaría otra alternativa que extraer la norma jurídica de mandato, que hace surgir de la asunción fáctica de la posición el deber de garante para la evitación del resultado, directamente de los tipos comisivos ${ }^{134}$.

Sin embargo, no sería necesario que sea el propio portador del bien jurídico protegido quien se coloque en la situación de peligro que el garante debe luego compensar. También podría ocurrir que el peligro, cuya evitación se ha confiado en el garante, derive de la circunstancia de que el hasta entonces garante le quite la protección concedida al bien jurídico. Del mismo modo deberían valorarse los casos en los cuales la confianza en la función de protección asumida por el garante, si bien no conduce a que el propio bien jurídico se exponga a un peligro, hace que otras medidas necesarias de seguridad no se cumplan. En este evento surgiría un momento de peligro que colocaría el destino del bien jurídico en manos del garante.

Un caso ejemplar es el de los padres negligentes que se han ido de viaje sin dejar un encargado al cuidado de sus niños y en que los amables vecinos le encargan a su muchacha que asuma tal labor, circunstancia por la cual ésta aún no se convierte en garante. Pues, advierte Gallas, dado que los vecinos no son garantes, la asunción de la función de protección por parte de la muchacha no significa aún quitarle a los niños la protección conferida hasta ahora. Se pregunta enseguida, si acaso la muchacha no se convertiría en garante en el caso de que, al negarse a asumir el cuidado, los vecinos mismos hubiesen asumido tal tarea o se la hubieran encargado a otra persona. Hablaría en el sentido de responder afirmativamente a esa pregunta la circunstancia aceptada generalmente de que es autor el sujeto que impide mediante intervención activa a que otro rescate el bien jurídico en peligro, sea éste garante o no ${ }^{135}$.

Gallas reconoce que su planteamiento tiene antecedentes en la historia dogmática del delito de omisión, cuando se asignaba significado a la acción previa y se veía en ella un momento de peligro - vid. supra 3.3. En este sentido no quedaría otra alternativa que, en el marco de la pregunta por la tipicidad, recurrir directamente al contenido material de injusto de la conducta del sujeto en su conjunto ${ }^{136}$.

\footnotetext{
${ }^{133}$ GALLAS, Studien, cit. nota n ${ }^{\circ} 11$, p. 78 y s.

${ }^{134}$ GALLAS, Studien, cit. nota n ${ }^{\circ} 11$, p. 80 y s.

${ }^{135}$ GALLAS, Studien, cit. nota $n^{\circ} 11$, p. 82 y s.

${ }^{136}$ GALLAS, Studien, cit. nota no 11 , p. 85 y s.
} 
En esa misma dirección, trata luego los casos de injerencia. Advierte la diferencia de ésta con los casos de asunción de una función de protección en la circunstancia de que en estos últimos la acción previa del sujeto que asume tal función no causa el peligro, en el cual el otro cae o ya se encuentra, sino que, por el contrario, tiene el sentido de evitar tal peligro. No obstante, la acción previa se manifestaría como peligrosa bajo el supuesto de que el garante fracasa en la función de protección asumida. El sujeto que asume la función de garantía se movería en la esfera de lo permitido y en este aspecto se parecería a los casos en que la acción previa crea un peligro permitido, por ejemplo, cuando se inicia una actividad productiva. En estos casos, el deber de garante presupone que el límite del riesgo permitido ha sido excedido ${ }^{137}$. Gallas sitúa este caso en el límite entre Derecho y moral, de modo que se inclina por la solución de que, si no concurren los presupuestos objetivos del deber de garante, sólo cabría el castigo por omisión de socorro. Y así como el causante de un accidente en la actividad productiva no sería garante, con mayor razón no lo sería el sujeto que tiene un derecho a realizar la acción creadora del peligro, tal como sucede en el ejercicio del derecho de legítima defensa ${ }^{138}$.

Finalmente, Gallas aborda los casos en los cuales resulta aplicable el criterio de la relación de dependencia. El principio de garantía presupone por lo menos que el bien jurídico, si no se encuentra ya en peligro por una acción previa del sujeto, sea dependiente del garante a consecuencia de una relación existente con antelación a la situación de necesidad. Tal relación, en la que una parte depende de la función de protección de la otra, existiría solamente entre el niño y aquellas personas que se encuentran a cargo de su cuidado, en primera línea, los padres. Entre los cónyuges, empero, no existiría tal relación de dependencia fáctica y recíproca. En cambio, en la relación del niño con los padres, éste tiene una necesidad permanente de protección, la que no se presentaría en la relación entre cónyuges ni en las demás relaciones familiares, de modo que en estos últimos casos resultaría aplicable sólo el tipo de omisión de socorro. También estos serían casos que se ubican en el límite del Derecho con la moral. En los tipos comisivos, en cambio, que pueden realizarse mediante omisión, el bien jurídico protegido se encontraría en el núcleo y la omisión puede, por ende, equipararse al hacer positivo solamente si, a la luz del fin de protección perseguido por el tipo, aparece como igualmente peligrosa ${ }^{139}$.

\subsection{Resumen}

En fin, y como puede constatarse, esta formulación del concepto de posición de garante integra los elementos desarrollados previamente en una síntesis, cuya influencia puede aún

\footnotetext{
${ }^{137}$ Recurre posteriormente a este criterio para fundar la posición de garante GIMBERNAT, Estudios, cit. nota $\mathrm{n}^{\mathrm{o}}$ 11, p. 248: "según mi concepción de la omisión impropia, la abstención equivale desvalorativamente a un delito de acción cuando la inactividad del encargado de un foco de peligro causante del resultado típico tenga como consecuencia (normativa) la transformación de ese foco de permitido en ilícito o la no reconducción al riesgo permitido de un foco que ha desbordado ya los límites jurídicamente tolerados”, pp. 294 y ss.

${ }^{138}$ GALLAS, Studien, cit. nota ${ }^{\circ} 11$, pp. 86 y ss.

${ }^{139}$ GALLAS, Studien, cit. nota ${ }^{\circ} 11$, p. 92 y s.
} 
ROJAS, Luis. "Delitos de omisión entre libertad y solidaridad".

percibirse en los planteamientos de otros autores contemporáneos ${ }^{140}$. El punto de partida del análisis del juicio de equivalencia en sede de tipicidad, ya fue fijado por Gallas en 1932. Dicho punto de partida supone la revisión de esta categoría en los términos de un "tipo de injusto". Es en esta medida que resulta luego posible identificar en el contenido de injusto material descrito por el tipo -y no en la causalidad-, el parámetro común a la acción y la omisión sobre cuya base se formula el juicio de equivalencia de ésta con aquélla.

Ese paso significa claramente una inflexión en el desarrollo de la dogmática moderna de la omisión impropia. Porque el parámetro común ya no es más de carácter descriptivo, como era la causalidad según el principio de la actividad previa. A contar de ese hito, el baremo común es eminentemente normativo, en el sentido de que identifica el "precepto de deber" subyacente al tipo como elemento de comparación.

Este baremo, sin embargo, no puede aplicarse por sí mismo. Requiere de un concepto que lo vuelva operativo. Pues bien, la formulación del concepto de posición de garante satisface precisamente esta necesidad. Lo explicita así Gallas cuando sostiene, frente a la jurisprudencia del $\mathrm{BGH}$, que el concepto de posición de garante solamente tiene sentido si se entiende como un criterio práctico-objetivo de los presupuestos bajo los cuales la no evitación de un resultado típico puede valorarse como equivalente a su producción mediante acción. En este sentido, la posición de garante se acuña como una fórmula resumida de los criterios práctico-objetivos que fundan el juicio de equivalencia entre acción y omisión.

\section{Crítica al principio de garantía y regreso a una teoría reformulada del deber jurí- dico}

\subsection{Crítica a la teoría del principio de garantía}

En el origen conceptual descrito precedentemente, la posición de garante es acuñada como una fórmula resumida de los criterios materiales que fundan la equivalencia entre omisión y comisión. Así concebida, se trata de una categoría que refleja fielmente el contexto espiritual de su época.

En efecto, en la época de nacimiento de la posición de garante, el concepto mismo de delito se encontraba en transformación. Se había acuñado la categoría moderna del tipo y éste empezaba a contener elementos antijurídicos, proceso este último que dio lugar a la categoría del "tipo de injusto", esto es, de un tipo que describe no solamente un hecho causal, sino

\footnotetext{
${ }^{140}$ Por ejemplo, en STREE, Walter, "Garantenstellung kraft Übernahme", en: Geerds/Naucke (eds.) Festschrift für Hellmuth Mayer, Berlin: Duncker \& Humblot, 1966, pp. 153 y ss. (no basta la asunción, tampoco la confianza generada por ésta en el portador del bien jurídico, sino que es necesario un "momento de peligro" derivado ya sea de la conducta de éste, que se expone al riesgo, o de la circunstancia que este mismo omite medidas de protección o que se inhibe la implementación de tales medidas por parte de otros sujetos obligados o dispuestos a la protección); BLEI, Hermann, "Garantenpflichtbegründung beim unechten Unterlassen", en: FS H. Mayer, cit. nota ${ }^{\circ}$ 140, pp. 122 y ss. (fundamento del deber de garante es siempre una conducta que lleva a que se prescinda de otras medidas de aseguramiento confiando en una promesa o en la presencia del obligado y que, por esta vía, puede generar un peligro para el bien jurídico protegido, si el sujeto que ha asumido tal función no interviene evitando el peligro), 138 y ss.
} 
Polít. crim. Vol. 13, № 26 (Diciembre 2018) Art. 2, pp. 682-783.

[http://www.politicacriminal.cl/Vol_13/n_26/Vol13N26A2.pdf]

que un injusto - un hecho antijurídico. Asimismo, se había desarrollado una teoría de la causalidad adecuada y ya se avanzaba en las bases conceptuales de la imputación objetiva. Es, entonces, este contexto de transformaciones en la forma de concebir el delito el que permite identificar el elemento común denominador de la acción y la omisión, ya no en la causalidad, como lo hacía antes el principio de la actividad previa -y también la teoría de la interferencia-, sino que, desde ahora, en el tipo.

En ese contexto espiritual, la teoría formal del deber jurídico ya no se encuentra a la orden del día. Según sus críticos, la equivalencia entre acción y omisión no puede depender más de la mera existencia formal de un deber jurídico. Sería necesario dotar de contenido material al deber jurídico. En este sentido, la posición de garante se concibe como un deber jurídico cualificado materialmente. En este punto confluyen los planteamientos antes expuestos.

Los criterios materiales que sirven a dicha cualificación giran en torno a la idea del momento de peligro. Este elemento, a su vez, se presenta en diversas formas ${ }^{141}$. En primer término, puede derivar de la circunstancia que el sujeto ha asumido una labor de protección. Así, dicho momento se genera por la confianza que la víctima ha depositado en el cumplimiento de tal función asumida efectivamente por el sujeto. Aquí se inserta el caso paradigmático del nadador intrépido. En otra constelación, cuyo caso ejemplar es el de la babysitter, el momento de peligro se genera por la circunstancia que la asunción efectiva de tal labor ha inhibido el funcionamiento de mecanismos de protección, que otros sujetos distintos de la víctima -terceros- podrían haber activado. Por otro lado, el momento de peligro puede presentarse en la forma de una relación fáctica de dependencia de la víctima respecto del sujeto, que existe previamente a la omisión misma. El ejemplo de esta forma se presenta en la relación de los hijos con respecto a sus padres. Finalmente, en los casos de injerencia, el sujeto genera directamente la situación de peligro, es decir, sin mediación ni de la conducta de la víctima ni la pasiva de terceros.

Esos son básicamente los criterios que dotan de contenido material a la posición de garante, de tal manera que esta no queda reducida al mero deber formal. La exigencia de tales criterios se traduce en la verificación de circunstancias fácticas concomitantes a la omisión del sujeto que generan, indirecta o directamente, un peligro para el bien jurídico protegido por la norma. La concurrencia de estas circunstancias convierte al sujeto en garante, vale decir, lo coloca en una posición de garantía en relación a dicho bien jurídico.

\footnotetext{
${ }^{141}$ Recurren actualmente también a este elemento SEELMANN, “GA 1989”, cit. nota n 5, p. 253: en el caso de los deberes de aseguramiento, estos suponen que se ha generado el peligro o que se ha asumido una responsabilidad por el mismo; en el caso de los deberes de protección, debe haberse retirado una disposición a la defensa o haberse asumido la responsabilidad por tal retiro; GIMBERNAT, Estudios, cit. nota n ${ }^{\circ} 11$, pp. 294 y ss. (la omisión impropia supone que un foco de peligro, que hasta entonces se mantiene dentro de lo permitido, se desestabiliza por la ausencia de medidas de precaución por parte del encargado de vigilarlo, pasando a convertirse dicho foco en prohibido), 302 y s. (dentro del ámbito familiar, la omisión impropia surge "cuando el pariente que haya resultado lesionado o muerto, como tal, constituye o se ha convertido en un foco de peligro, a consecuencia de su inmadurez, de una enfermedad preexistente o de cualquiera otra circunstancia”), entre otros.
} 
ROJAS, Luis. "Delitos de omisión entre libertad y solidaridad".

Pues bien, planteado de ese modo, el concepto de posición de garante es una reformulación moderna del principio de la actividad previa desarrollado en la segunda mitad del siglo XIX. Su formulación obedece a la misma pretensión de dotar de contenido material a la omisión del sujeto, desprovista ésta de causalidad. Se trata del mismo intento de llenar el vacío que implica la "nada de la omisión" ahora con estos elementos. Pero, en vez de simplemente reconducir la causalidad a la acción previa del sujeto, tal como opera dicho principio, el concepto de posición de garante lo que hace es reconducir el peligro para el bien jurídico protegido por la norma a las reseñadas circunstancias fácticas concomitantes a la omisión del sujeto.

En esa medida, la crítica formulada al principio de la actividad previa recobra validez - vid. supra 3.4. Desde luego, el contenido y alcance de la obligación del garante radica en la evitación del resultado. No obstante, y tal como lo plantea ahora la teoría del principio de garantía, esa obligación se funda no meramente en la existencia formal de un deber jurídico, sino que en dichas circunstancias concomitantes que generan precisamente el peligro, a cuya evitación se encuentra llamado el garante. En definitiva, la posición de garante surge de las circunstancias concomitantes que generan el mismo peligro cuya realización luego el sujeto omite evitar.

Respecto de la exigencia del deber jurídico, la formulación del concepto de posición de garante trae la misma consecuencia que el principio de la actividad previa. Esto es, también en este contexto dicha exigencia se vuelve superflua. Pues, lo decisivo ahora son los criterios materiales que fundan la posición de garante. Por eso también es que se habla de una "posición" de garante o de una "relación" de garantía. Porque lo determinante no es el deber formal, sino que la posición "material" en la cual se encuentra el sujeto en relación con el bien jurídico protegido por la norma. Según el principio de garantía, el origen formal del deber jurídico es irrelevante, tal como se postula en el caso del nadador intrépido y en el de la babysitter.

Sin embargo, esta consecuencia inmanente al concepto de posición de garante plantea un dilema. Pues, si el deber de garante se funda meramente en la asunción de una labor de protección o en la circunstancia de que se genera un momento de peligro para el bien jurídico, se corre así el riesgo de favorecer y agudizar una tendencia expansiva de la responsabilidad por omisión impropia, cuya morigeración justamente pretendía la formulación originaria del concepto. En virtud del criterio material de la asunción de una labor de protección, por ejemplo, se allana el camino para derivar sin más una posición de garante en los casos de una comunidad de vida o de peligro $^{142}$.

Si el concepto de posición de garante es fiel a una perspectiva normativa, no puede prescindir de un elemento netamente normativo. El problema es que, tras el rechazo explícito a la teoría formal del deber jurídico, éste no se extrae más ni de una ley extrapenal ni de un contrato. Así, el principio de garantía se ve confrontado a la dificultad de identificar un elemento normativo, sin recurrir a las fuentes jurídicas reconocidas por dicha teoría. Y esta dificultad se agrava, desde el momento en que tampoco puede radicar tal elemento en un mero deber moral.

${ }^{142}$ Vid. sobre esta tendencia expansiva GIMBERNAT, Estudios, cit. nota n ${ }^{\circ} 11$, pp. 154 y ss. 
En ese escenario, aún queda la alternativa de sostener que el deber de garante surge de las circunstancias fácticas de la asunción efectiva de una labor de protección o del momento de peligro antes descrito. Pero esta última alternativa implicaría simplemente concederle "fuerza normativa a lo fáctico", al costo de violar un postulado básico de la lógica deóntica, según el cual un imperativo no puede derivarse de un conjunto de premisas formado exclusivamente por descripciones fácticas ${ }^{143}$.

Gallas es consciente de este dilema. Y no ve otro camino que acudir directamente al fin y sentido del tipo en cuestión, esto es, de la ley penal misma. Sin embargo, el fin y sentido del tipo - en rigor, de la norma que le subyace- de un delito de resultado radica sencillamente en la protección del bien jurídico y la pregunta aquí concierne al origen del deber de evitar la lesión a este mismo bien jurídico. La vía de escape seguida conduce a una tautología. Para salir de ella, se requiere de un elemento distinto a la propia norma de comportamiento, en virtud del cual ésta opere no solamente en la forma de una prohibición, sino que también en la de un mandato. Pues bien, ese elemento externo a la propia norma de comportamiento no es otro que el deber jurídico especial fundado formalmente.

\subsection{El supuesto de la existencia formal del deber jurídico en los casos analizados}

Es interesante observar que varios de los criterios materiales usados por el principio de garantía involucran cuestiones que posteriormente se tematizan bajo la categoría de la imputación objetiva. Si bien en la época de formulación del principio de garantía ya se habían instalado las bases de este concepto, la doctrina no disponía aún de una teoría general con criterios normativos diferenciados, como se reconoce hoy en día. En este sentido, el desarrollo posterior de la teoría de la imputación objetiva permitiría replantear y recodificar los criterios materiales del principio de garantía en el lenguaje más avanzado de esta teoría.

Así, por ejemplo, en el caso del nadador intrépido, éste se expone al peligro confiando en la ayuda que habría de prestarle el sujeto eventualmente obligado a ella. Ya en la formulación del caso es posible notar que la responsabilidad penal atribuida al sujeto presupone la existencia de la obligación. El principio de garantía, empero, disimula este elemento formal $\mathrm{y}$, en su lugar, extrae el criterio material fundante de la equivalencia de la posterior omisión de auxilio con la acción creadora del riesgo descrita en el tipo correspondiente a partir de las circunstancias copulativas que el sujeto induce a la víctima a exponerse al peligro y que ésta confía en aquél. Lo determinante, según la teoría del principio de garantía, sería este momento de peligro generado por el propio sujeto obligado luego a compensarlo.

Pues bien, el mismo caso planteado ahora a la luz de la teoría de la imputación objetiva se discutiría bajo el acápite del principio de autorresponsabilidad de la víctima y sus límites. La forma en que juega este principio con sus límites depende del fundamento material postulado respecto del mismo. Si el fundamento se ve en el derecho a la autodeterminación

\footnotetext{
${ }^{143}$ Cfr. HARE, Richard M., Die Sprache der Moral, Frankfurt: Suhrkamp, 1972, p. 50 y s.; WEINBERGER, Ota, Norm und Institution, Wien: Manz, 1988, p. 60: ,(3) una consecuencia informativa normativa sólo puede obtenerse de una clase de premisas que contiene al menos una proposición normativa (una proposición práctica); (3') el deber no se sigue del ser" (postulados de indeducibilidad).
} 
ROJAS, Luis. "Delitos de omisión entre libertad y solidaridad".

de la persona y la autopuesta en peligro de la víctima todavía se mantiene dentro del ejercicio de este derecho fundamental, quiere decir que ya la conducta del sujeto que favorece o posibilita fácticamente dicha autopuesta en peligro no puede calificarse de antijurídica ${ }^{144}$.

La aplicación del principio de autorresponsabilidad de la víctima, empero, puede topar con un límite precisamente en la constelación en que el sujeto tiene una obligación de garantía con respecto a ella ${ }^{145}$. Si, por ejemplo, el sujeto tiene un deber de protección de la víctima y ésta se expone al riesgo para sus propios bienes jurídicos, pero bajo la confianza de que el sujeto va a cumplir su deber y éste, por el contrario, lo infringe, entonces ya no puede sostenerse sin más que la víctima ha ejercido su derecho a la autodeterminación. Si se concluye que ésta no ha obrado libremente, entonces no hay autorresponsabilidad y, por ende, habría responsabilidad del sujeto, concurriendo los demás requisitos de imputación. Para llegar a esta conclusión, sin embargo, se requiere partir de la existencia de tal deber.

Ahora bien, y volviendo el caso del nadador intrépido, éste se expone al peligro confiando en que el sujeto cumpla su promesa de brindarle apoyo, en el evento de que sea necesario. Según la teoría del principio de garantía, el sujeto tiene este deber por la circunstancia que el nadador ha prescindido de mecanismos de resguardo en virtud de dicha confianza depositada en aquél. El contrato y la existencia formal de la obligación serían irrelevantes, mientras que lo determinante sería la asunción de la labor de protección y la concurrencia de dichas circunstancias de peligro - un momento de peligro.

Sin embargo, un deber jurídico, cuya infracción pueda justificar una excepción al principio de autorresponsabilidad de la víctima, no puede derivar meramente de un compromiso, que tiene un alcance reducido al ámbito de la moral. Tampoco puede derivar de circunstancias puramente fácticas, como serían la confianza de la víctima o la desarticulación efectiva de mecanismos de resguardo, por parte de esta misma o de terceros. Aquí la teoría del principio de garantía cae en el dilema antes reseñado.

Una vía de escape posible sería recurrir directamente al fin y sentido del tipo penal, es decir, al fin de protección de la norma jurídico-penal. No obstante, y de seguirse este camino, restaría pendiente aclarar el origen del deber jurídico cuyo contenido radica precisamente en la evitación de la lesión al bien jurídico protegido por dicha norma. Pareciera que el principio de garantía presupone aquí la existencia formal de la obligación, a la que luego solamente dota de contenido material. Dicho principio, empero, se formula con la pretensión explícita de sustituir al deber jurídico fundado formalmente con estos criterios materiales, pretensión que en definitiva se ve frustrada si en el análisis del caso se termina por suponer la existencia de tal deber.

\footnotetext{
${ }^{144}$ Cfr. MURMANN, Uwe, Die Selbstverantwortung des Opfers im Strafrecht, Berlin e.o.: Springer, 2005, pp. 264 y ss., 318 y ss., 379 y ss.

${ }^{145}$ Cfr. FRISCH, Tatbestandsmässiges Verhalten, cit. nota $\mathrm{n}^{\mathrm{o}} 103$, pp. 177 y ss., 194 y ss., 211 y ss., quien, sin embargo, no reduce la excepción a la existencia de tal clase de deberes, sino que incluye otros casos de reprobación jurídica del riesgo, pese a la autopuesta en peligro de la víctima, como por ejemplo, aquellos en los cuales su propio cuidado ha sido asumido por otro.
} 
Polít. crim. Vol. 13, No 26 (Diciembre 2018) Art. 2, pp. 682-783.

[http://www.politicacriminal.cl/Vol_13/n_26/Vol13N26A2.pdf]

Algo similar ocurre en el caso de la babysitter encargada por los amables vecinos de los niños negligentemente abandonados por sus padres. Se trataría de un caso a analizar bajo la lupa del así llamado principio de confianza. Su aplicación, empero, presupone que los sujetos involucrados en el contexto de riesgo cumplen cada uno sus deberes correspondientes, en términos tales de que si cualquiera de ellos los infringe, ya no puede invocar legítimamente la confianza $y$, por ende, procede en principio la imputación objetiva ${ }^{146}$. El principio de confianza opera bajo el supuesto de la existencia de deberes. Y, en el caso, el problema es que los vecinos no tienen en relación con los niños ninguna obligación distinta que el deber general de solidaridad. Su infracción, en consecuencia, no fundaría más responsabilidad que la característica del tipo general de omisión de socorro. Otro tanto sucedería con la babysitter. Vale decir, si los vecinos no tienen otra obligación distinta que el deber general de solidaridad, entonces el encargo que le hacen a la babysitter tampoco podría fundar un deber distinto.

Gallas intuye este problema y por eso reconoce, ante la constatación patente que "los vecinos no son garantes", que el solo encargo a la babysitter no la convierte en "garante", pues no implicaría aún retirar la protección previamente conferida. Aquí sencillamente se presupone que los vecinos confieren previa y efectivamente protección a los niños. Porque, según la teoría del principio de garantía, lo que coloca al sujeto en la posición especial de garantía sería un momento de peligro derivado ya sea de la circunstancia que el originariamente obligado desarticula mecanismos de protección o que se inhibe la activación de medidas de aseguramiento por parte de terceros. En el caso en cuestión, dicho momento de peligro se presentaría cuando la babysitter asume efectivamente su labor de protección, desactivando de ese modo los mecanismos de aseguramiento de los propios vecinos o de otras personas. Sin embargo, Gallas no formula directamente esta afirmación, sino que duda y se pregunta si acaso la babysitter no se convertiría en "garante" en el momento en que, de negarse a asumir el encargo, los vecinos habrían asumido ellos mismos el cometido o se lo habrían encargado a otras personas - ¿a otros vecinos amables?

Se inclina por responder afirmativamente la pregunta en base a una comparación de ese momento del caso con una hipótesis en la cual un sujeto activamente impide la realización de una acción salvadora del bien jurídico. No obstante, ya el momento consistente en la negativa de la babysitter en asumir el encargo supone una variación fáctica del caso, cuando la pregunta radica en el origen de la posición de garante por dicha asunción. Pero, aun cuando se concediera la variación del caso, la comparación postulada es doblemente desacertada. Primero, porque tal hipótesis presupone ya el inicio del curso salvador y éste, a su vez, la situación de peligro, cuestión que aún no ocurre en el caso. Segundo, el curso salvador es interrumpido mediante una acción, que pone una condición positiva del resultado, de modo que esta hipótesis excede el ámbito del delito de omisión ${ }^{147}$.

\footnotetext{
${ }^{146}$ Pues, como hace ver PUPPE, Ingeborg, Die Erfolgszurechnung im Strafrecht, Baden-Baden: Nomos, 2000, pp. 133 y ss., nadie puede excusar su propia infracción del deber invocando la infracción del deber por parte de otro.

${ }^{147}$ Cfr. PUPPE, "ZStW 1980", cit. nota n 41, pp. 899 y ss., 903 y ss, quien, si bien trata este grupo de casos en el marco de las condiciones negativas del resultado, lo distingue en su interior de los casos de omisión; según GIMBERNAT, Estudios, cit. nota $\mathrm{n}^{\circ}$ 11, pp. 456 y ss., se trataría de una tercera forma de realización del tipo junto al delito de acción y la omisión impropia.
} 
ROJAS, Luis. "Delitos de omisión entre libertad y solidaridad”.

La comparación hipotética con la negativa de la babysitter a asumir el encargo revela un nuevo intento de reconducir el peligro a la acción previa del sujeto. En efecto, en la hipótesis de interrupción de un curso salvador, la responsabilidad no depende de si el sujeto ostenta o no la calidad de "garante" $"$. La configuración de la omisión impropia, empero, sí exige que el sujeto tenga un deber de realizar la acción impeditiva. Y, en el caso de la babysitter, la pregunta es justamente si ésta tiene tal deber desde el momento en que asume el encargo, no que lo rechaza. Otra vez pareciera que la aplicación de los criterios ofrecidos por el principio de garantía supone ya aquello que se pretende fundar, i.e. la existencia de esa obligación.

Piénsese en una variante inversa del caso de la babysitter en la cual los padres diligentes pasan una tarde de verano en la casa de los vecinos que dispone de una refrescante piscina y, para descansar un momento, contratan a la muchacha a cambio de una remuneración justa para que cuide a los niños. Respecto de los padres, la teoría formal del deber jurídico fundaría el deber de evitación en el art. 222 inciso $2^{\circ}$ del Código civil. Según la teoría del principio de garantía, en cambio, el deber de garante derivaría de la relación fáctica de dependencia de los niños con respecto a sus padres. Para ambas teorías existiría el deber, aunque la fundamentación del mismo sería diferente: una formal y la otra material.

La duda se presentaría respecto de la babysitter. Conforme a la teoría formal del deber, ella tendría un deber jurídico de evitación surgido del contrato celebrado ${ }^{149}$. En el caso de una desgracia ocurrida con los niños, empero, su responsabilidad penal por omisión se supedita a la concurrencia de ciertos requisitos adicionales. En primer lugar, en el momento crítico, ella debe encontrarse en condiciones fácticas de poder realizar la acción impeditiva. Segundo, y supuesta dicha capacidad, debe existir un nexo de causalidad formulado en base a un juicio de probabilidad, esto es, de una probabilidad rayana en la certeza de evitación del resultado en el evento hipotético de que la babysitter hubiese realizado la acción impeditiva. La verificación de este nexo de causalidad puede complementarse ya sea mediante un juicio de adecuación -así Traeger: teoría de la causalidad adecuada- o, posteriormente, con la aplicación de criterios de imputación objetiva. En este último orden de consideraciones, resultaría pertinente el principio de confianza, cuya aplicación en el caso se traduce en la observación de la concurrencia de alguna de sus excepciones, por ejemplo, en el evento de que existiesen indicios que la propia babysitter o los padres infringen sus propios deberes límite a la confianza legítima.

En cambio, según la teoría del principio de garantía, el deber de garante de la babysitter se supedita a que, como consecuencia de la asunción fáctica de la labor de protección, los padres desactiven efectivamente sus mecanismos de resguardo o los vecinos inhiban mecanismos de protección. Recién en ese momento de peligro nacería el deber de garante. Antes de

\footnotetext{
${ }^{148}$ Cfr. SAMSON, FS Welzel, cit. nota n ${ }^{\circ}$ 9, p. 596.

${ }^{149}$ El deber existe, aun cuando el contrato se encuentre aquejado de un vicio de nulidad absoluta o relativa art. 1681 y ss. Código civil; la afirmación precedente parte de la premisa del rechazo mayoritario a la teoría de la inexistencia en el Derecho civil chileno, cfr. recientemente SAN MARTÍN, Lilian, "La teoría de la inexistencia y su falta de cabida en el Código Civil chileno", Revista Chilena de Derecho vol. 42 n 3 (2015), pp. 759 y ss.
} 
ese momento, en ausencia de un deber de garante, la babysitter siempre puede excusarse aduciendo que los padres -¿o los vecinos?- todavía se encuentran a cargo de los niños. Y, después de ese momento, el principio de confianza ya no resultaría aplicable, pues el nacimiento del deber de garante presupone que los padres han desactivado sus mecanismos de protección, de modo que la babysitter no podría invocar confianza legítima así como tampoco podrían analizarse los límites al principio, en tanto éstos presuponen la existencia de deberes de terceros -y los vecinos no tienen más que un deber general de solidaridad.

De ese modo queda en evidencia el problema del principio de garantía, cual es que hace depender el juicio de equivalencia entre omisión y comisión de la concurrencia de una posición de garante entendida en sentido material ${ }^{150}$. Como fórmula resumida de los criterios materiales que fundan dicha equivalencia, apenas deja espacio para la observación de otros criterios de imputación objetiva.

La formulación del concepto de posición de garante se explica en una época en la cual, si bien se había dado el paso trascendental a una concepción del tipo como abarcador del injusto y, por lo tanto, se podía identificar en el tipo así comprendido el parámetro común para formular el juicio de equivalencia entre delito de acción y de omisión, aún no se había desarrollado una teoría de la imputación objetiva con la pretensión general de ofrecer una concepción del injusto típico común a ambas formas de manifestación del delito. Pues bien, el desarrollo ulterior de una teoría de la imputación objetiva que satisface esa pretensión general ha vuelto prescindible el concepto de posición de garante entendido de la forma descrita.

\subsection{Acerca del regreso a una teoría reformulada del deber jurídico}

Si el tipo de injusto de un delito de resultado se compone de causalidad y de imputación objetiva, como se suele entender actualmente, entonces la configuración de una omisión impropia presupone la existencia formal de un deber jurídico especial. Tanto la comprobación del nexo de causalidad como luego la aplicación de criterios de imputación objetiva, como por ejemplo, el principio de autorresponsabilidad de la víctima, el principio de confianza o el criterio del riesgo permitido, presuponen en este ámbito la existencia de tal deber.

Para la verificación del nexo de causalidad, es preciso formular un juicio de probabilidad acerca de lo que habría sucedido en el evento hipotético de que el sujeto hubiese realizado la acción impeditiva ordenada. Colocado en ese escenario hipotético, resulta muy difícil saber si esto habría ocurrido, sin representarse la acción impeditiva que el sujeto concretamente debía realizar. La acción impeditiva concreta que se agrega hipotéticamente difícilmente puede pensarse sin considerar el alcance del deber ${ }^{151}$. Frente a la misma situación

\footnotetext{
${ }^{150}$ De ahí también la crítica y el rechazo a esta categoría en FREUND, Erfolgsdelikt, cit. nota no 109, pp. 39 y ss., 44 y ss.

${ }^{151}$ De ahí que en el ámbito del delito impropio de omisión no pueda separarse la comprobación de la causalidad de la aplicación del criterio de la conducta alternativa hipotética conforme a deber, cfr. al respecto FREUND, Georg, en: Joecks/Miebach (eds.) Münchener Kommentar zum Strafgesetzbuch, 3. ed., München: Beck, 2017, § 13, nm. 210 y ss., 218 y ss.; la pregunta que resta en pie, y que por sí misma justifica una
} 
ROJAS, Luis. "Delitos de omisión entre libertad y solidaridad".

fáctica de peligro, por ejemplo, una enfermedad grave de un niño, lo que debe hacer el médico es distinto que el deber de acción de sus padres o cuidadores.

Por su parte, la aplicación de criterios de imputación objetiva en el ámbito del delito de omisión, como se vio, necesita fijar un punto de partida en el deber jurídico del sujeto. Por cierto, y esto ya era bastante claro en la formulación de la teoría formal del deber jurídico, la sola infracción del deber jurídico no fundamenta aún la equivalencia entre omisión y comisión. Es necesario ahora observar la pertinencia de aplicar alguno de los criterios de imputación objetiva.

Por ejemplo, el art. 102 del Código civil establece, entre otros, un deber de auxilio mutuo entre los cónyuges -y lo mismo hace el art. 14 de la Ley de acuerdo de unión civil. En el caso concreto, a pesar de la existencia formal del deber, el principio de autorresponsabilidad de la víctima impediría afirmar la configuración ya de una infracción a tal deber, en la medida en que la decisión del cónyuge o conviviente civil pueda calificarse como ejercicio de su derecho a la autodeterminación -0 , con otras palabras, se podría hablar de un incumplimiento del deber de auxilio mutuo para los efectos jurídico-civiles, mas no de equivalencia entre omisión y comisión para efectos penales.

Justamente la función que cumplen los criterios de imputación objetiva reside en que permiten observar el fundamento material común de la responsabilidad penal tanto por acción como por omisión. Así, por ejemplo, si resulta pertinente la aplicación del principio de confianza, significa que, en el caso concreto, la situación de peligro para el bien jurídico se enmarca todavía en el espacio de la confianza legítima, y si bien existe formalmente un deber jurídico, en definitiva no se justifica materialmente la restricción de la libertad del sujeto obligado.

Es aquí donde recobra vigencia el juicio de ponderación entre bien jurídico y ámbito de libertad del sujeto que U. Mayer creía necesario para el juicio de equivalencia entre omisión y comisión. Sólo que en esa época, en ausencia todavía de una teoría de la imputación objetiva, tal criterio de orden material fundaba la posición de garantía del sujeto para efectos de su responsabilidad por omisión. Un desarrollo diferenciado de la teoría de la imputación objetiva que, por ejemplo, distingue, por un lado, la pregunta por la legitimación de la restricción de la libertad de acción del ciudadano -cuestión que atañe al fundamento de la norma de conducta - y, por el otro, criterios adicionales de legitimación para la aplicación de la norma de sanción ${ }^{152}$, ubicaría sistemáticamente dicho juicio de ponderación a propósito de la pregunta fundamental por la legitimación de la norma de conducta. En la medida en que la aplicación de dicho criterio material pertenece a esta pregunta básica de legitimación, sistemáticamente deja de tematizarse en el marco de la cuestión previa sobre la configuración de la posición de garante. En este sentido, el desarrollo ulterior y diferenciado de la teoría de la imputación objetiva ha vuelto prescindible el concepto de posición

\footnotetext{
investigación de mayor alcance, es si tal separación se justifica todavía en el ámbito del delito de acción, cfr. PUPPE, Ingeborg, "System der objektiven Zurechnung", GA (2015), p. 208, 213 nota 49, quien tacha de un error la separación trazada por Honig entre causalidad e imputación objetiva, al mismo tiempo que sugiere la necesidad de un regreso al concepto de causalidad adecuada en el sentido de von Kries.

${ }^{152}$ En este sentido, FRISCH, Tatbestandsmässiges Verhalten, cit. nota $n^{\circ} 103$, pp. 71 y ss.
} 
Polít. crim. Vol. 13, No 26 (Diciembre 2018) Art. 2, pp. 682-783.

[http://www.politicacriminal.cl/Vol_13/n_26/Vol13N26A2.pdf]

de garante en tanto fórmula resumida de los criterios materiales que fundan el mentado juicio de equivalencia entre acción y omisión ${ }^{153}$.

La existencia formal de un deber jurídico especial de evitación constituye, empero, un requisito básico de la responsabilidad por omisión impropia. La configuración de esta clase de responsabilidad penal exige, además de la infracción de tal deber jurídico, la verificación de un nexo de causalidad y la consideración de otros criterios de imputación objetiva. Pero, en una sociedad como la moderna, donde prácticamente todos los ámbitos de la vida se encuentran regulados jurídicamente, no resulta plausible pretender fundar responsabilidad jurídico-penal por omisión en base solamente a elementos fácticos y criterios materiales, como por ejemplo la generación de un "momento de peligro".

Aunque resulte paradójico, aquí radica la intuición correcta de Feuerbach al formular la versión originaria de la teoría del deber jurídico, que exigía la concurrencia de un fundamento jurídico especial para el castigo de la omisión. En su reformulación moderna, genera certeza jurídica al introducir un filtro con la exigencia de la existencia formal de un deber jurídico de evitación. Como ya lo había postulado Traeger, para estar en presencia de tal deber jurídico, no es suficiente un deber general de auxilio -como el que subyace al tipo de omisión de socorro o al de omisión de denuncia de un crimen próximo a cometerse. Es necesaria la existencia de un deber jurídico especial. Tal deber existe, cuando el titular del bien jurídico amenazado tiene correlativamente el derecho a exigir de una persona determinada la evitación del peligro - derecho cuya existencia precisamente se cuestiona en la situación fáctica de la omisión de socorro o de la omisión de denuncia ${ }^{154}$. En un ordenamiento jurídico positivo, a su vez, los derechos y las obligaciones correlativas surgen exclusivamente de la ley o de un contrato. Este es el postulado central de la teoría formal del deber jurídico en su formulación moderna.

De acuerdo a este razonamiento, entonces, la diferencia entre un deber jurídico especial y el deber general de auxilio reside en la existencia de tal plexo de derechos y obligaciones correlativas. Esta diferencia no puede ser introducida por la propia ley penal cuya aplicación se ventila en el caso concreto, sin exponerse a una tautología. La ley penal positiviza el deber jurídico de evitación en la forma negativa de una prohibición o positiva de un man-

\footnotetext{
${ }^{153}$ Este es el planteamiento central de FREUND, Erfolgsdelikt und Unterlassen, cit. nota n ${ }^{\circ} 109$, pp. 44 y ss., 47 y s., vale decir, en su función de señalar los elementos, circunstancias y exigencias normativas que deben concurrir para la equivalencia, la posición de garante misma no puede ser un elemento parcial del tipo; sin embargo, Freund, en el lugar de la posición de garante, acuña la categoría de "responsabilidad especial", bajo la cual entiende una "relación especial" del destinatario potencial de la norma de conducta con el curso dañoso a evitar (pp. 68 y ss.); esta responsabilidad especial puede derivar, por una parte, de una relación con el origen del peligro -las así llamadas posiciones de garante de una fuente de peligro- (pp. 159 y ss.) o, de otra parte, de la competencia por el "lugar de destino" del peligro -las así llamadas posiciones de garante de protección- (pp. 265 y ss.); sin embargo, no es posible determinar la existencia de tal relación del sujeto con el "origen del peligro" o con el "lugar de destino" del mismo, sin recurrir a la existencia formal del deber jurídico, deber que, entonces, se torna precisamente en el criterio que permite diferenciar la responsabilidad general de la especial en el sentido de Freund.

${ }^{154}$ Pregunta que se encuentra detrás del cuestionamiento a la legitimación de tipos basados en el principio de solidaridad, por ejemplo, MORGENSTERN, Henrike, Unterlassene Hilfeleistung. Solidarität und Recht, Frankfurt a.M.: Peter Lang, 1997, pp. 58 y ss., 122 y ss.
} 
ROJAS, Luis. "Delitos de omisión entre libertad y solidaridad".

dato, con el fin de proteger el bien jurídico correspondiente -fin de protección de la norma. Pero, es la existencia de un deber jurídico especial la que vuelve obvia la transformación de una prohibición en un mandato, cuyo incumplimiento constituye el presupuesto fundamental de la responsabilidad por omisión impropia. Si se parte de la distinción usual en la doctrina entre una norma primaria de conducta y una norma secundaria de sanción ${ }^{155}$, tal deber jurídico vuelve operativa la norma de comportamiento en la forma de un mandato, cuya infracción mediante omisión constituye un presupuesto básico de la aplicación legítima de la correspondiente norma de sanción penal.

Ese deber jurídico surge, en consecuencia, de una ley distinta que la penal, vale decir, de una ley extrapenal -o pre-penal-, por ejemplo, de Derecho civil o de Derecho administrativo. Sin embargo, no puede tratarse de cualquier ley extrapenal, sino que de una pertinente al caso. Y es pertinente si la norma jurídica pre-penal incluye dentro de sus fines la protección del mismo interés jurídico resguardado por la norma de comportamiento jurídico-penal, cuya aplicación se ventila en el caso concreto. Más precisamente, el mismo bien jurídico protegido por la norma de conducta, cuya infracción es exigida para la aplicación legítima de la correspondiente norma de sanción penal. No cabe exigir que sea su fin exclusivo, pues regularmente tales normas jurídicas pre-penales cumplen una función configuradora que supera con creces el acotado fin de la no lesión a un bien jurídico. Regulan y configuran positivamente múltiples intereses jurídicos. En este sentido, basta que exista consistencia entre el fin de protección de la norma jurídica extrapenal y de la norma de comportamiento jurídico-penal.

Por otra parte, tampoco es requisito que el fin de protección se encuentre formulado explícitamente en el texto de la norma jurídica pre-penal. Sería bastante absurdo exigir que el art. 222 inciso $2^{\circ}$ del Código civil dijera expresamente que "los padres deben evitar la muerte de sus hijos" o que el art. 102 del mismo código declarase que "los cónyuges deben procurarse recíprocamente evitar una enfermedad grave". La norma jurídica extrapenal podría decirlo así, pero no es requisito que lo haga. La operación determinante, como ya la practicaba el Reichsgericht en la jurisprudencia arriba citada -supra 3.2., consiste en extraer el deber jurídico especial a partir de una fuente formal ${ }^{156}$.

\footnotetext{
${ }^{155}$ Sobre las raíces de esa distinción, RENZIKOWSKI, Joachim, "Die Unterscheidung von primären Verhaltens- und sekundären Sanktionsnormen in der analytischen Rechtstheorie“, en: Dölling/Erb (eds.) Festschrift für Karl Heinz Gössel zum 70. Geburtstag, Heidelberg: C.F. Müller, 2002, pp. 3 y ss.

${ }^{156}$ En un sentido similar FREUND, Erfolgsdelikt und Unterlassen, cit. nota ${ }^{\circ} 150$, pp. 33 y ss., mantiene la exigencia de un deber jurídico como un elemento imprescindible de una adecuada teoría de la equivalencia, pero advierte que aquélla no debe entenderse en un sentido positivista, sino que lo determinante es el contenido material del ordenamiento jurídicamente relevante de conducta, es decir, en el ámbito pre-jurídico penal interesa solamente si dicho ordenamiento significa una solución adecuada del conflicto entre libertad de acción e intereses en la conversación de bienes; luego, al analizar la categoría de la responsabilidad especial, en su modelo de responsabilidad común por acción y omisión (impropia) basado en dos pilares -"utilidad del seguimiento de la norma" y "responsabilidad especial", el deber jurídico extraído formalmente parece cumplir una función indiciaria, así, por ejemplo, los deberes jurídico civiles de aseguramiento en el tráfico constituyen una sub-exigencia del deber de evitación de peligros, pp. 166 y ss.; algo similar ocurre con los "deberes de protección", ámbito en el cual Freund no ve una diferencia fundamental con los deberes de evitación de peligros, pp. 265 y ss.
} 
Lo dicho precedentemente vale también respecto del contrato como fuente de un deber jurídico especial ${ }^{157}$. La función del contrato radica precisamente en crear derechos y obligaciones correlativas entre las partes. En este sentido, su existencia introduce una diferencia con el deber general de auxilio. Para este efecto, debe reunir la misma exigencia de pertinencia que atiende al fin de protección de la norma. Al igual que la ley extrapenal, acá tampoco es requisito que tal fin sea exclusivo -regularmente no lo será- ni que sea explícito - también sería absurdo exigir que, por ejemplo, el contrato de un médico con su paciente diga explícitamente que aquél hará lo posible para evitar la muerte de éste.

Más allá de la ley y del contrato, como ya lo intuyera el propio Feuerbach, no existen fuentes del deber jurídico especial. Así resuelve la teoría formal del deber jurídico la cuestión de las fuentes posibles del mismo. Sin embargo, su formulación todavía es ciega frente al contenido y alcance del deber jurídico especial.

Una clasificación del deber jurídico especial a partir de su contenido sólo fue posible de la mano de un pensamiento orientado materialmente, tal como fuera planteado, por ejemplo, por U. Mayer. Éste distingue, como se vio -supra 4.1., dos clases de posiciones especiales del sujeto, derivada, una, de la relación del mismo con el peligro y, la otra, de la relación del sujeto con el titular del bien jurídico. De esta manera, se adelanta a la formulación ulterior de la así llamada teoría de las funciones $^{158}$.

${ }^{157}$ De otra opinión, TRAEGER, "Das Problem”, cit. nota n ${ }^{\circ}$ 64, pp. 82 y ss.

${ }^{158} \mathrm{Si}$ por teoría de las funciones se entiende una clasificación de las posiciones de garante como elemento del tipo del delito de omisión impropia, pues bien, tal teoría no se formula en la obra de Armin KAUFMANN, Dogmatik, cit. nota $\mathrm{n}^{\circ}$ 17: Kaufmann parte de la premisa que solamente una acción final puede ser objeto de una norma (pp. 2 y ss.); al mismo tiempo, en el plano óntico, sostiene que si bien puede hablarse de causalidad entre la acción omitida y la no ocurrencia de un acontecimiento, no puede afirmarse lo mismo entre el sujeto y la acción omitida (pp. 60 y ss.); si bien la omisión supone la capacidad de una dirección final, ella misma no se somete a tal dirección (pp. 74 y ss.); existe una diferencia fundamental entre acción y omisión, pues, si bien la capacidad de acción es común a ambas, falta en ésta el dolo entendido como voluntad de realización, el poder fáctico final sólo se refiere a la acción omitida (pp. 81 y ss.); esa diferencia atañe a la estructura misma de la omisión -vale decir: esta tiene una estructura inversa a la acción, de ahí la formulación del principio de inversión, según el cual la misma consecuencia jurídica se presenta cuando concurre respecto de la acción omitida la estructura inversa que en el delito de acción -por ejemplo, punibilidad no de la "tentativa de omisión", sino que de la omisión del intento de realizar la acción ordenada a pesar de la capacidad de acción-, lo que implica que no puede hablarse de "comisión mediante omisión", sino que de omisión de la acción debida a pesar de la capacidad de acción (pp. 85 y ss.); esa estructura invertida se presenta en el delito propio de omisión (pp. 91 y ss.), donde Kaufmann ya sostiene que el deber no pertenece a ningún elemento en la estructura del delito, pues el tipo se orienta a la norma (p. 132 y s.); respecto de los delitos impropios de omisión, sostiene que toda su construcción dogmática se orienta al "fin político-jurídico" de igualar el marco penal con el delito de acción (pp. 239 y ss.); respecto de la concepción de Nagler-vid. supra 4.3., en cuanto a la posición de garante como elemento no escrito del tipo, la rechaza y sostiene que es una exigencia del delito impropio de omisión que no realiza ningún tipo del delito de acción, sino que el tipo (inexistente) del delito impropio de omisión, pues solamente una acción puede contravenir una prohibición, en cambio, una omisión no puede infringir una norma de prohibición (pp. 249 y ss.); el mandato de evitación del resultado es una norma sui generis, ergo, el delito impropio de omisión se subsume bajo un tipo especial no escrito (pp. 259 y ss.; es decir, inexistente por el principio de legalidad en su dimensión de lex scripta); el incumplimiento del mandato de evitación del resultado, no se subsume jamás bajo el correspondiente tipo de prohibición, pues la omisión no es un caso especial del delito de acción, sino que un caso genuino del delito de omisión (pp. 275 y ss.); el delito impropio de omisión exige además una relación cercana del sujeto del deber con el objeto, pero que significa un incremento cuantitativo del 
ROJAS, Luis. "Delitos de omisión entre libertad y solidaridad".

Como es sabido, dicha teoría clasifica las posiciones de garante entre las que se basan en una función de vigilancia de una fuente de peligro determinada y las que consisten en una función de protección a un sujeto determinado. La clasificación entre posiciones de garante de vigilancia y de protección, empero, y por mucho que se trate de reconducirla a circunstancias fácticas y criterios materiales ${ }^{159}$, depende, en última instancia, de la clase de deberes que el ordenamiento jurídico positivo impone al sujeto en relación a una fuente de peligro o a otro sujeto. Si este establece deberes jurídicos de aseguramiento, en el sentido de que obligan a organizar de tal manera la fuente de peligro que de ésta no deriven cursos lesivos para terceros, se habla de una posición de garante de vigilancia ${ }^{160}$. Si, en cambio, el

contenido de injusto del delito propio de omisión, por lo que no existe una diferencia dogmática entre ambos, sino que sólo en el plano axiológico (pp. 276 y ss.); se trata de un delito sui generis según tipo, injusto y culpabilidad, ninguna solución dogmática puede colmar el vacío legal, pues el tipo de omisión impropia no solamente es abierto, sino que completamente abierto y no escrito (pp. 281 y ss.); es en este contexto, esto es, luego de negarle a la posición de garante su status de un elemento no escrito del tipo del delito de acción, donde Kaufmann distingue los mandatos de garante, según su objeto, entre la función de protección y la vigilancia de una determinada fuente de peligro, para enseguida acudir al orden de las reflexiones axiológicas, dentro del cual se encuentra la pregunta por la relación de garantía (pp. 283 y ss.); no existe una diferencia dogmática entre delito propio e impropio de omisión, sino que sólo una necesidad político criminal de someterlo al marco penal del delito de comisión (p. 304); el deber de garante no es ni un elemento del tipo ni un momento de antijuridicidad, no aparece en ninguna sede de la estructura del delito (p. 308); unos años después, SCHÖNE, Wolfgang, Unterlassene Erfolgsabwendungen und Strafgesetz. Zur gesetzlichen Regelung "unechter" Unterlassungsdelikte, Köln e.o.: Heymanns, 1974, extraería la consecuencia de este planteamiento; luego de analizar las diferentes figuras de omisión repartidas en los tipos de la parte especial (pp. 41 y ss., 175 y ss., 235 y ss.) -delitos propios de omisión, tipos que contemplan la omisión como alternativa típica a la acción y tipos de omisión tras una descripción activa de la conducta, arriba a la conclusión que la omisión impropia, según el Derecho vigente en esa época justo antes de la introducción de una cláusula de equivalencia en la parte general, se encuentra al margen del texto legal, por lo que la madre que deja de amantar a su hijo recién nacido responde sólo por una omisión de socorro - $\$ 330$ c StGB (!), pues la búsqueda de satisfacer necesidades político criminales mediante su castigo a título de omisión impropia contraviene el principio de legalidad consagrado en el art. 103 párr. $2^{\circ}$ de la Ley fundamental.

${ }^{159}$ Así, por ejemplo, SCHÜNEMANN, Bernd, cita nota $n^{\circ}$ 24, pp. 275 y ss., 324 y ss.; lo sigue ROXIN, Claus, Strafrecht, Allgemeiner Teil, t. II, München: Beck, 2003, § 32 nm. 17 y ss., 33 y ss., 107 y ss.

${ }^{160}$ GRÜNEWALD, Anette, Zivilrechtlich begründete Garantenpflichten im Strafrecht?, Berlin: Duncker \& Humblot, 2001, pp. 119 y ss., 124 y ss., critica la extracción, en particular, de los deberes del tráfico desde el Derecho civil para fundar deberes de garante en el Derecho penal, entre otras razones, por la ampliación que esos deberes han experimentado para fundar responsabilidad civil en casos que, de acuerdo a los criterios tradicionales de la responsabilidad penal, sería incompatible; tales deberes son concebidos por la jurisprudencia como una cláusula general que suma indeterminación a la regla ya poco taxativa del $\S 13$ StGB; en efecto, como reporta VON BAR, Christian, "Entwicklungen und Entwicklungstendenzen im Recht der Verkehr(sicherungs)pflichten", Juristische Schulung, no 3 (1988), pp. 169 y ss., el tradicional "deber general de aseguramiento" se ha ampliado a los "deberes del tráfico" exigiendo sólo un peligro incrementado y considerando otros criterios como las expectativas de confianza; frente a esta tendencia expansiva, sin embargo, A. GRÜNEWALD, Garantenpflichten, cit. nota $\mathrm{n}^{\circ} 160$, pp. 133 y ss., exige para la responsabilidad penal, fiel a un concepto negativo de Derecho (en el sentido de Hegel), una acción previa que o bien genera un peligro o implica asumir una responsabilidad por una fuente de peligro, junto con la consideración de la legítima confianza surgida de tal asunción, es decir, los mismos elementos fácticos provenientes del principio de la actividad previa, posteriormente reformulados como criterios materiales por el principio de garantía, vid. supra 3.3. y 4; efectivamente, el problema reseñado existe, pero es importante recordar que ya en la extracción del deber jurídico desde una fuente del Derecho civil se aplica un criterio de selección a partir del fin de protección de la norma de comportamiento jurídico-penal respectiva; luego, el deber jurídico así fundado, se observa desde la perspectiva de los criterios materiales de imputación objetiva, sin que exista ninguna 
mismo ordenamiento jurídico impone deberes de protección de un sujeto determinado, se habla de una posición de garante de protección. Dicha teoría no hace más que transponer en el lenguaje de las funciones los deberes jurídicos de aseguramiento, por un lado, y los deberes jurídicos de protección, por el otro. En este sentido, la función de vigilancia es una expresión sintética de los deberes jurídicos de aseguramiento, mientras que la función de protección es una fórmula resumida de esta segunda clase de deberes jurídicos. Aquí radica el límite y al mismo tiempo la virtud de la teoría de las funciones, esto es, en ofrecer un criterio de clasificación de los deberes jurídicos especiales, no a partir de sus fuentes, sino que a la luz del contenido y alcance del deber.

En conclusión, y tras el desarrollo de la teoría de la imputación objetiva, la categoría de la posición de garante, entendida como una serie de criterios materiales sumada al deber jurídico especial de evitación, se ha tornado prescindible. La aplicación de los criterios de imputación objetiva, empero, supone la existencia formal de un deber jurídico especial. Este deber puede emanar de una ley extrapenal o de un contrato. Desde el punto de vista de su contenido y alcance, puede clasificarse en deberes jurídicos de aseguramiento de una fuente de peligro determinada y en deberes jurídicos de protección a un sujeto determinado.

La existencia formal de un deber jurídico especial, sin embargo, constituye solamente un requisito básico, por lo que su incumplimiento no funda aún el juicio de equivalencia entre omisión y comisión. Para la formulación de tal juicio, además del nexo de causalidad, es menester considerar los demás criterios de imputación objetiva, si su aplicación es pertinente en el caso concreto. En definitiva, son estos criterios materiales, y no la existencia formal de un deber jurídico especial, los determinantes para fundar el mentado juicio de equivalencia. Pues, la formulación de este juicio supone la concurrencia de los mismos elementos y criterios que legitiman la aplicación de la norma de sanción contemplada para el correspondiente delito de acción ${ }^{161}$.

Estos criterios materiales de imputación objetiva, empero, no pueden sustituir la eventual falta de un deber jurídico especial fundado formalmente en el caso concreto. Desde un punto de vista metodológico, es menester diferenciar claramente entre la pregunta por la existencia formal de un deber jurídico especial, por un lado, y la consideración de los criterios de imputación objetiva, por el otro. Asimismo, y según la versión de la teoría de la imputación objetiva que se siga, cabe distinguir adicionalmente entre criterios que dicen relación con la infracción del deber jurídico especial, como por ejemplo el riesgo permitido, el principio de autorresponsabilidad de la víctima o el de confianza, por un lado, y criterios

necesidad de transponer los criterios de imputación tendencialmente más laxos de la responsabilidad civil por daños; crítico también frente a la tendencia expansiva que implica la accesoriedad al Derecho privado para los efectos de fundar deberes de garante, SEELMANN, Kurt, "Privatrechtlich begründete Garantenpflichten?", en: Schmidt (ed.) Vielfalt des Rechts - Einheit der Rechtsordnung?, Berlin: Duncker \& Humblot, 1994, pp. 88 y ss., frente a la cual propone recurrir a los criterios tradicionales de imputación jurídico-penal que, en el ámbito del delito de omisión (pp. 94 y ss.), se traduce en "la exigencia de concebir la omisión jurídicopenalmente relevante sólo como la no inhibición de cursos causales propios”, exigencia que rige del mismo modo tanto respecto de los deberes de aseguramiento como de los deberes de protección: "en los dos casos, el obligado debe haber puesto por sí mismo mediante su conducta previa la causa para la posterior lesión” (p. 96).

${ }^{161}$ En este sentido, FREUND, Erfolgsdelikt, cit. nota n ${ }^{\circ} 109$, pp. 51 y ss., 85 y ss. 
ROJAS, Luis. "Delitos de omisión entre libertad y solidaridad".

que atañen a la imputación del resultado, $v . g r .:$ la conducta alternativa hipotética conforme al mismo deber jurídico.

El planteamiento expuesto coloca al menos dos problemas pendientes de análisis. La primera cuestión atañe a la consecuencia de esta tesis respecto de la asunción fáctica de una labor de vigilancia o protección. Pues, si se exige la existencia formal de un deber jurídico, la mera circunstancia de que un sujeto asume tal labor no sería suficiente. La segunda pregunta dice relación con la compatibilidad de la injerencia con este postulado regreso a la teoría formal del deber jurídico. Aquella supone abordar la tautología antes reseñada que implicaría derivar el deber jurídico especial de la circunstancia que el sujeto causó la situación de peligro para el bien jurídico protegido por la norma respectiva. Dada la extensión que ha alcanzado ya el presente trabajo, sin embargo, parece conveniente ahora extraer algunas conclusiones y luego seguir con el análisis de ambas cuestiones en otro lugar. Fiel a la crítica formulada antes al principio de la actividad previa - vid. supra 3.4, ambos problemas deben abordarse en su momento por separado.

\section{Conclusiones}

1. Si se parte de una concepción del Derecho penal regida por el principio neaminem laedere, la realización de un delito de acción constituye ya una infracción a este principio, mientras que una omisión por sí misma no lo contraviene. En la concepción originaria de Feuerbach, el carácter delictivo -dañoso o injusto- de la omisión presupone la concurrencia de un fundamento jurídico especial, derivado a su vez de la ley o de un contrato.

2. Un concepto de delito fundado en el elemento de la causalidad, como el que impera en la doctrina durante el siglo XIX, se identifica con el delito de acción. Su carácter delictivo resulta evidente, en tanto ésta produce causalmente un resultado en la esfera jurídica de otro un daño. En cambio, bajo esa concepción dominante, la omisión misma no es causal de ningún efecto antijurídico. Ante este supuesto vacío, tanto el principio de la actividad previa como la teoría de la interferencia pretenden explicar el carácter delictivo de la omisión mediante la identificación de una acción causal previa de tal efecto o que sucede al interior del campo de fuerzas psicológicas del sujeto, respectivamente. El lugar del fundamento jurídico especial es ocupado así por dichas circunstancias fácticas externas o internas concomitantes a la omisión.

3. Impertérrita, la jurisprudencia del Reichsgericht parte de la premisa de la causalidad de la omisión y verifica adicionalmente la concurrencia de un deber jurídico de evitación, que a su vez extrae de la ley, de un contrato o de un hacer precedente peligroso. Frente a ella, la doctrina mayoritaria ya de la primera mitad del siglo XX sigue partiendo de la ausencia de causalidad y ve, por consiguiente, en la exigencia de un deber jurídico de evitación el riesgo de sujetar la responsabilidad jurídico-penal exclusivamente a su incumplimiento. Como dicha doctrina parte de la premisa de la ausencia de causalidad en la omisión, observa un vacío que se colmaría con la exigencia meramente formal del deber jurídico y su incumplimiento. 
Polít. crim. Vol. 13, No 26 (Diciembre 2018) Art. 2, pp. 682-783.

[http://www.politicacriminal.cl/Vol_13/n_26/Vol13N26A2.pdf]

4. La formulación del principio de garantía responde a la necesidad de dotar de contenido material a la exigencia meramente formal del deber jurídico de evitación. Según esta teoría, la posición de garante consiste en una relación especial con el bien jurídico protegido, surgida ya sea de la circunstancia de haber generado indirectamente -mediante la conducta de la propia víctima o por la inhibición fáctica de mecanismos de resguardo que terceros podrían haber activado- la situación de peligro que lo amenaza o de la existencia de una situación de dependencia fáctica de éste respecto del sujeto.

5. Si se tiene presente, por un lado, la revisión a la cual ha sido sometido el concepto de causalidad desde hace algunas décadas y se suscribe, por el otro, el desarrollo que ha significado la teoría de la imputación objetiva para el concepto general de injusto, la posición de garante, entendida como fórmula resumida de criterios materiales que dotan de contenido de injusto a la omisión, ha perdido su justificación originaria. Junto a la verificación del nexo de causalidad, basada en un juicio de probabilidad rayana en la certeza de evitación del resultado en el evento hipotético de realización de la acción impeditiva, se requiere la existencia formal de un deber jurídico especial que ordene la realización de esta última acción. Tal deber existe siempre que una ley extrapenal o un contrato funda el derecho correlativo de la víctima a exigir del sujeto la realización de la acción impeditiva y, por ende, la evitación del resultado. La víctima de una situación de peligro generada casualmente -supuesto fáctico del tipo de omisión de socorro- o que se encuentra amenazada por la inminente realización de un delito por obra de un tercero -supuesto fáctico de un tipo de omisión de denuncia-, no tiene tal derecho a exigir del sujeto la realización de la acción impeditiva, aun cuando éste se encuentre en condiciones fácticas de poder ejecutarla. Dicho desde la otra perspectiva, el sujeto que se encuentra con esa víctima se somete únicamente a un deber general de auxilio-solidaridad.

6. Comprobada la causalidad, la infracción del deber jurídico especial de evitación funda el juicio de equivalencia entre la omisión y la acción descrita en el tipo respectivo. Al igual que en este último ámbito, el injusto del delito, no obstante, puede decaer por la aplicación de los criterios de imputación objetiva. En los términos de la omisión impropia, en caso de resultar aplicable un criterio de imputación objetiva - por ejemplo, riesgo permitido, principio de autorresponsabilidad de la víctima o principio de confianza-, en definitiva, no existe infracción del deber jurídico especial de evitación -o si existe, ésta no explica la realización del resultado-, constatación que entonces impide la formulación del juicio de equivalencia.

7. En clave de teoría de las normas, la existencia formal de un deber jurídico especial vuelve operativa la norma de comportamiento, subyacente al tipo del delito de acción respectivo en los términos de una prohibición, también en la forma de un mandato. Si existe un deber jurídico especial de evitación y un derecho correlativo a exigir la realización de la acción impeditiva, emanados ambos de una fuente formal, entonces la operación de transformación de la prohibición en un mandato de realización de tal acción se vuelve obvia. De modo equivalente al delito de acción, cuya realización infringe la prohibición subyacente al tipo correspondiente, el injusto de la omisión impropia deriva del incumplimiento del mandato que resulta de esa operación previa de transformación de la norma de comportamiento. 
ROJAS, Luis. "Delitos de omisión entre libertad y solidaridad".

\section{Bibliografía}

ALCÁCER, Rafael, “Autonomía, solidaridad y deber de socorro (un apunte histórico)", Anuario de Derecho penal y Ciencias penales vol. LIII (2000), pp. 361-411.

BAYERTZ, Kurt, "Begriff und Problem der Solidarität", en: BAYERTZ, Kurt, (ed.): Solidarität, Begriff und Problem, Frankfurt a.M.: Suhrkamp, 1998, pp. 11-53.

BLEI, Hermann, "Garantenpflichtbegründung beim unechten Unterlassen”, en: Geerds/Naucke (eds.) Festschrift für Hellmuth Mayer, Berlin: Duncker \& Humblot, 1966, pp. 119-143.

BINDING, Karl, Die Normen und ihre Übertretung, t. I, 4. ed., Leipzig: Scientia Verlag (Aalen), 1922.

BINDING, Die Normen und ihre Übertretung, t. II, 1. parte, 2. ed., Leipzig: Scientia Verlag (Aalen), 1914.

BÖHM, Alexander, Die Rechtspflicht zum Handeln bei den unechten Unterlassungsdelikten, Dissertation, Frankfurt a.M.: sin editorial, 1957.

BUSTOS, Juan, FLISFISCH, Ángel, POLITOFF, Sergio, “Omisión de socorro y homicidio por omisión”, Revista de Ciencias Penales, $3^{\mathrm{a}}$ época, nº 3, t. XXV (1966), pp. 163184.

DROST, "Der Aufbau der Unterlassungsdelikte”, Der Gerichtssaal (GS), t. 109 (1937), pp. $1-63$. 
Polít. crim. Vol. 13, No 26 (Diciembre 2018) Art. 2, pp. 682-783.

[http://www.politicacriminal.cl/Vol_13/n_26/Vol13N26A2.pdf]

FEUERBACH, Paul Johann Anselm, Lehrbuch des gemeinen in Deutschland gültigen peinlichen Rechts, 14. ed., Giessen: Scientia Verlag (Aalen), 1847.

FREUND, Georg, Erfolgsdelikt und Unterlassen, Köln e.o.: Heymanns, 1992.

FREUND, Georg, § 13, en: Joecks/Miebach (coords.) Münchener Kommentar zum Strafgesetzbuch, 3. ed., München: Beck, 2017.

FRISCH, Wolfgang, Tatbestandsmässiges Verhalten und Zurechnung des Erfolgs, Heidelberg: C.F. Müller, (reimpresión) 2012.

GALLAS, Wilhelm, “Zur Revision des § 330c StGB“, Juristenzeitung, nº 13/14 (1952), pp. 396-400.

GALLAS, Wilhelm, Studien zum Unterlassungsdelikt, Heidelberg: C.F. Müller, 1989.

GIMBERNAT, Enrique, Estudios sobre el delito de omisión, 2a ed., Montevideo/Buenos Aires: BdeF, 2013.

GLASER, Julius, Abhandlungen aus dem örsterreichischen Strafrecht, t. I, Wien: Hendler \& Comp., 1858.

GRÜNEWALD, Anette, Zivilrechtlich begründete Garantenpflichten im Strafrecht?, Berlin: Duncker \& Humblot, 2001.

HARE, Richard M., Die Sprache der Moral, Frankfurt a.M.: Suhrkamp, 1972.

HEGEL, G. W. F., Doctrina del derecho, los deberes y la religión para el curso elemental, Buenos Aires: Biblos, 2010.

HERZBERG, Rolf Dietrich, „Die Kausalität beim unechten Unterlassungsdelikt“, Monatsschrift für Deutsches Recht, no 11 (1971), pp. 881-883.

HERZBERG, Rolf Dietrich, Die Unterlassung im Strafrecht und das Garantenprinzip, Berlin/New York: De Gruyter, 1972.

HRUSCHKA, Joachim, Kant und der Rechtsstaat, Freiburg/München: Karl Alber, 2015.

JAKOBS, Günther, Die strafrechtliche Zurechnung von Tun und Unterlassen, Opladen: Westdeutscher Verlag, 1996.

KANT, Immanuel, Die Metaphysik der Sitten, $1^{\mathrm{a}}$ ed. 1797; $2^{\mathrm{a}}$ ed. 1798, Frankfurt a.M.: Suhrkamp, 1978.

KARGL, Walter, "Unterlassene Hilfeleistung (§ 323c StGB), Zum Verhältnis von Recht und Moral”, Goltdammer's Archiv für Strafrecht (1994), pp. 247-264. 
ROJAS, Luis. "Delitos de omisión entre libertad y solidaridad".

KISSIN, Siegfried, Die Rechtspflicht zum Handeln bei den Unterlassungsdelikten, BreslauNeukirch: Alfred Kurtze, 1933.

KÜHL, Kristian, Freiheitliche Rechtsphilosophie, Baden-Baden: Nomos, 2008.

KÜHL, Kristian, "Zur Anwendung des Solidaritätsbegriffs auf die unterlassene Hilfeleistungspflicht nach $\S 323 c$ StGB”, en: von Hirsch/Neumann/Seelmann (eds.) Solidarität im Strafrecht, Baden-Baden: Nomos, 2013, pp. 93-102.

MAÑALICH, Juan Pablo, Norma, causalidad y acción, Madrid e.o.: Marcial Pons, 2014.

MAYER, Ulrich, Die besonderen Tatbestandsmerkmale der unechten Unterlassungsdelikte, Dissertation, Heidelberg: sin editorial, 1934.

MERKEL, Adolf, "Von den Unterlassungsverbrechen, beziehungsweise dem negativen Unrechte, und ihrem Gegensatz, und von dem Verhältnisse der ersteren zu den Polizeivergehen“ en: Kriminalistische Abhandlungen, t. II, Leipzig: Breitkopf und Härtel, 1867.

MERKEL, Adolf, Lehrbuch des deutschen Strafrechts, Stuttgart: Ferdinand Enke, 1889.

MERKEL, Paul, Begehung durch Unterlassung, Nürnberg: W. Tümmels Buch- und Kunstdruckerei, 1895.

MEZGER, Edmund, Strafrecht, München/Leipzig: Duncker \& Humblot, 1931.

MORGENSTERN, Henrike, Unterlassene Hilfeleistung. Solidarität und Recht, Frankfurt a.M.: Peter Lang, 1997.

MURMANN, Uwe, Die Selbstverantwortung des Opfers im Strafrecht, Berlin e.o.: Springer, 2005.

NAGLER, Johannes, "Die Problematik der Begehung durch Unterlassung”, Der Gerichtssaal (GS), t. 111 (1938), pp. 1-121.

OSSANDÓN, María Magdalena, "Comisión por omisión del delito de favorecimiento de la prostitución de menores", en: La Ciencia Penal en la Universidad de Chile. Libro homenaje a los profesores del Departamento de ciencias penales de la Facultad de Derecho de la Universidad de Chile, Santiago: sin editorial, 2013, pp. 435-461.

PAWLIK, Michael, “Unterlassene Hilfeleistung: Zuständigkeitsbegründung und systematische Struktur”, Goltdammer's Archiv für Strafrecht (1995), pp. 360-372.

PAWLIK, Michael, “'Das dunkelste Kapitel in der Dogmatik des Allgemeinen Teils‘. Bemerkungen zur Lehre von den Garantenpflichten”, en: Heinrich/ Jäger/ 
Polít. crim. Vol. 13, No 26 (Diciembre 2018) Art. 2, pp. 682-783.

[http://www.politicacriminal.cl/Vol_13/n_26/Vol13N26A2.pdf]

Achenbach/ Amelung/ Bottke/ Schünemann/ Haffke/ Wolter (eds.) Festschrift für Claus Roxin zum 80. Geburtstag, Berlin/New York: De Gruyter, 2011, pp. 931-945.

PAWLIK, Michael, Das Unrecht des Bürgers, Tübingen: Mohr Siebeck, 2012.

PAWLIK, Michael, "Solidaridad como categoría de legitimación jurídico-penal: El ejemplo del estado de necesidad agresivo justificante", Revista de estudios de la justicia, $\mathrm{n}^{\mathrm{0}}$ 26 (2017), pp. 222-247.

PUPPE, Ingeborg, "Der Erfolg und seine kausale Erkärung im Strafrecht”, Zeitschrift für die gesamte Strafrechtswissenschaft, vol. 92 (1980), pp. 863-911.

PUPPE, Ingeborg, Die Erfolgszurechnung im Strafrecht, Baden-Baden: Nomos, 2000.

PUPPE, Ingeborg, “System der objektiven Zurechnung”, GA (2015), pp. 203-218.

RADBRUCH, Gustav, Der Handlungsbegriff in seiner Bedeutung für das Strafrechtssystem, Darmstadt: Wissenschaftliche Buchgesellschaf, 1967.

RENZIKOWSKI, Joachim, "Die Unterscheidung von primären Verhaltens- und sekundären Sanktionsnormen in der analytischen Rechtstheorie", en: Dölling/Erb (eds.) Festschrift für Karl Heinz Gössel zum 70. Geburtstag, Heidelberg: C.F. Müller, 2002, pp. 3-13.

ROBLES, Ricardo, “Deberes negativos y positivos en Derecho penal”, InDret n 4 (2013), pp. 1-21.

ROXIN, Claus, Strafrecht Allgemeiner Teil, t. II, München: Beck, 2003.

RUDOLPHI, Hans Joachim, Die Gleichstellungsproblematik der unechten Unterlassungsdelikte und der Gedanke der Ingerenz, Göttingen: Otto Schwartz \& Co., 1966.

SAMSON, Eric, "Begehung und Unterlassung", en Stratenwerth/Kaufmann/Geilen/Hirsch/ Schreiber/Jakobs/Loos (eds.) Festschrift für Hans Welzel zum 70. Geburtstag, Berlin/New York: De Gruyter, 1971, pp. 578-603.

SAN MARTÍN, Lilian, "La teoría de la inexistencia y su falta de cabida en el Código Civil chileno", Revista Chilena de Derecho, vol. 42 N. 3 (2015), pp. 745-784.

SÁNCHEZ-VERA, Javier, Pflichtdelikt und Beteiligung, Berlin: Duncker \& Humblot, 1999.

SCHÖNE, Wolfgang, Unterlassene Erfolgsabwendungen und Strafgesetz. Zur gesetzlichen Regelung “unechter” Unterlassungsdelikte, Köln e.o.: Heymanns, 1974. 
ROJAS, Luis. "Delitos de omisión entre libertad y solidaridad".

SCHÜNEMANN, Bernd, Fundamento y limites de los delitos de omisión impropia, Madrid/Barcelona: Marcial Pons, 2009.

SEELMANN, Kurt, "Opferinteressen und Handlungsverantwortung in der Garantenpflichtdogmatik", Goltdammer's Archiv für Strafrecht (1989), pp. 241256.

SEELMANN, Kurt, “Solidaritätspflichten im Strafrecht?”, en: Jung/Müller-Dietz/Neumann (eds.), Recht und Moral, Baden-Baden: Nomos, 1991, pp. 295-304.

SEELMANN, Kurt, "Privatrechtlich begründete Garantenpflichten?", en: Schmidt (ed.) Vielfalt des Rechts - Einheit der Rechtsordnung?, Berlin: Duncker \& Humblot, 1994, pp. 85-96.

SILVA SÁNCHEZ, Jesús María, “Zur Dreiteilung der Unterlassungsdelikte”, en: Schünemann/Achenbach/Bottke/Haffke/Rudolphi (eds.) Festschrift für Claus Roxin zum 70. Geburtstag, Berlin/New York: De Gruyter, 2001, pp. 641-650.

SILVA SÁNCHEZ, Jesús María, El delito de omisión, $2^{\mathrm{a}}$ ed., Montevideo/Buenos Aires: BdeF, 2003.

SPANGENBERG, „Über Unterlassungsverbrechen und deren Strafbarkeit“, Neues Archiv für Criminalrecht, t. IV sección 4 (1821), pp. 527-557.

SPENDEL, Günter, „Zur Dogmatik der unechten Unterlassungsdelikte“, Juristenzeitung n ${ }^{\text {}}$ 5/6 (1973), pp. 137-144.

STEINVORTH, Ulrich, “Kann Solidarität erzwingbar sein?”, en: Bayertz (ed.) Solidarität, Begriff und Problem, Frankfurt a.M.: Suhrkamp, 1998, pp. 54-85.

STREE, Walter, "Garantenstellung kraft Übernahme", en: Geerds/Naucke (eds.) Festschrift für Hellmuth Mayer zum 70. Geburtstag, Berlin: Duncker \& Humblot, 1966, pp. 145-164.

TRAEGER, Ludwig, "Das Problem der Unterlassungsdelikte im Straf- und Zivilrecht", en: Festgaben für Ludwig Enneccerus, Marburg i.H.: Elwert'sche Buchhandlung, 1913, pp. 5-126.

VARONA, Daniel, Derecho penal y solidaridad, Madrid: Dykinson, 2005.

VON BAR, Christian, "Entwicklungen und Entwicklungstendenzen im Recht der Verkehr(sicherungs)pflichten", Juristische Schulung, no 3 (1988), pp. 169-174.

VON BURI, Maximiliam, "Die Kausalität der Unterlassung”, Zeitschrift für die gesamte Strafrechtswissenschaft (ZStW) (1881), pp. 400-413. 
Polít. crim. Vol. 13, No 26 (Diciembre 2018) Art. 2, pp. 682-783.

[http://www.politicacriminal.cl/Vol_13/n_26/Vol13N26A2.pdf]

VOGEL, Joachim, Norm und Pflicht bei den unechten Unterlassungsdelikten, Berlin: Duncker \& Humblot, 1993.

WELZEL, Hans, Das Deutsche Strafrecht, 11. ed., Berlin: De Gruyter, 1969.

WELZEL, Hans, "Zur Dogmatik der echten Unterlassungsdelikte", Neue Juristische Wochenzeitung $\mathrm{n}^{\mathrm{o}} 9$ (1953), pp. 327-329.

WEINBERGER, Ota, Norm und Institution, Wien: Manz, 1988.

WILENMANN, Javier, "Sobre la estructura argumentativa de los delitos de omisión impropia”, en: Cárdenas/Ferdman (coords.) El Derecho Penal como Teoría y como Práctica. Libro Homenaje a Alfredo Etcheberry, Santiago: La Ley/Thomson Reuters, 2016, pp. 275-322. 